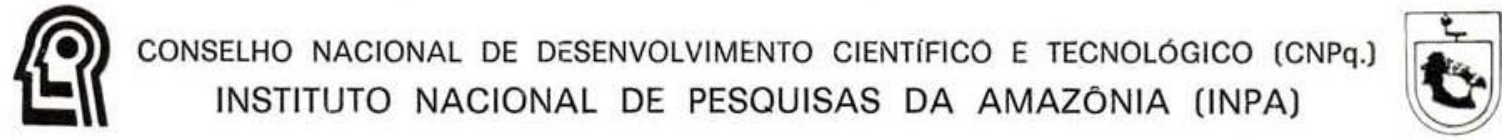

\title{
Guia preliminar para as Briófitas freqüentes em Manaus e adjacências
}

\author{
Dana Griffin, III \\ Universidade de Flórida \\ Gainesville, Flórida
}

ACTA AMAZONICA - Vol. 9(3): Suplemento 
GRIFFIN III, Dana

Guia preliminar para as Briófitas freqüentes em Manaus e adjacências. Acta Amazonica, Manaus, 9(3) : Suplemento, set., 1979.

$67 \mathrm{p}$. ilust.

1. Briófitas - Amazonas 2. Fitogeografia 1. Título.

\section{CDD 588.811}

581.9811

CDU 582.32(811.3)

$581.9(811.3)$

RESUMO : O outor apresenta as famílias, os gêneros e, dentro destes quando possível, as espécies de briófitas conhecidas até o momento, freqüentemente encontradas na floresta tropical úmida, num raio de $150 \mathrm{~km}$ ao redor de Manaus, Estado do Amazonas, Brasil. Chaves artificiais para a separaçāo das classes e, em casos particulares, de gênero e espécies sāo também apresentadas. Cada familia é descrita resumidamente sob o ponto de vista morfalógico, de habitat preferencial e de distribuiçăo geográfica geral. Os termos técnicos utillizados nas descriçōes encontram-se definidos na maioria dos dicionários de Botânica ou nos textos sobre morfologia de briófitas, facilitadas com a inclusẫo no trabalho de 536 figuras. 
Introdução $\ldots \ldots \ldots \ldots \ldots \ldots \ldots \ldots \ldots \ldots \ldots \ldots \ldots \ldots \ldots \ldots \ldots \ldots \ldots$

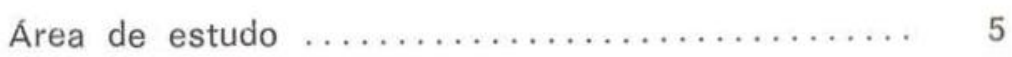

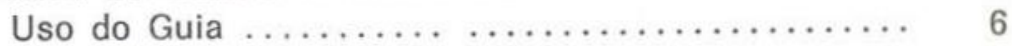

Descrições de famílias $\ldots \ldots \ldots \ldots \ldots \ldots \ldots \ldots \ldots \ldots$

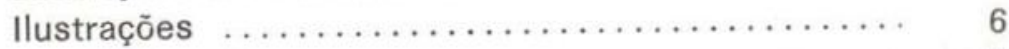

Agradecimentos $\ldots \ldots \ldots \ldots \ldots \ldots \ldots \ldots \ldots \ldots \ldots \ldots \ldots \ldots$

Chaves $\ldots \ldots \ldots \ldots \ldots \ldots \ldots \ldots \ldots \ldots \ldots \ldots \ldots \ldots \ldots$

As classes de Bryophyta ................. 8

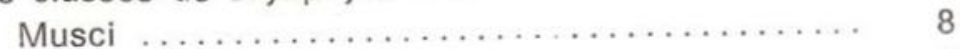

Hepaticae e Anthocerotae ............... 13

Descrições das familias com notas auxiliares ...... 17

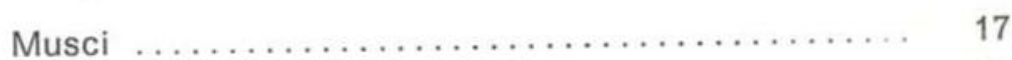

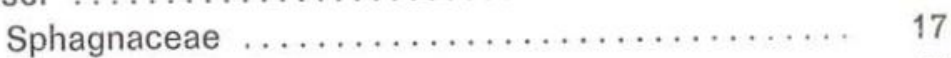

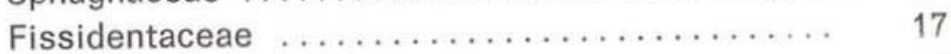

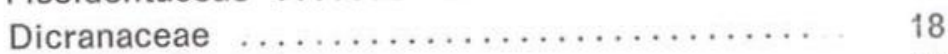

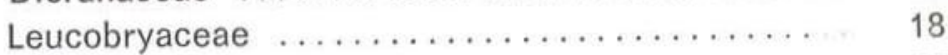

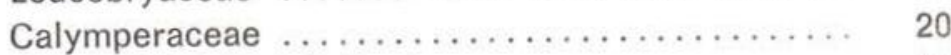

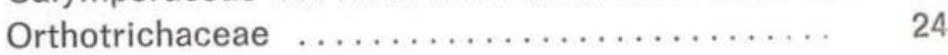

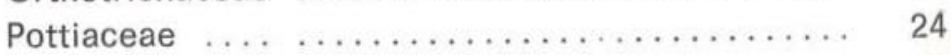

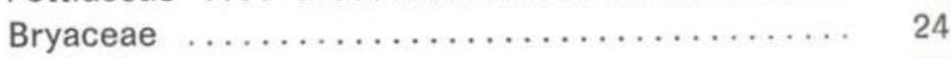

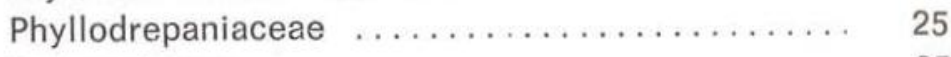

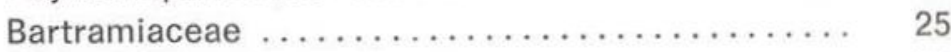

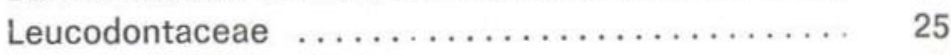

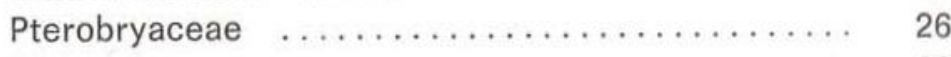

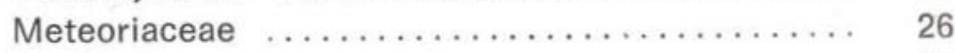

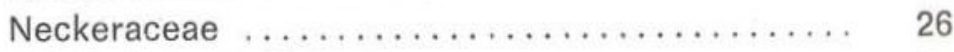

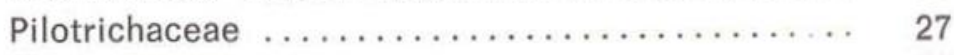

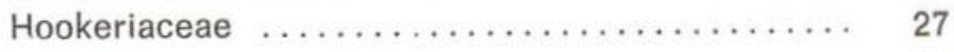

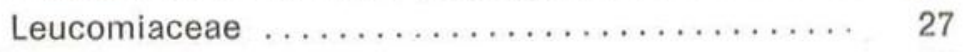

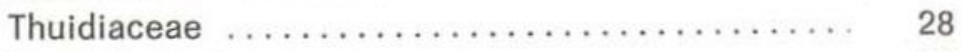

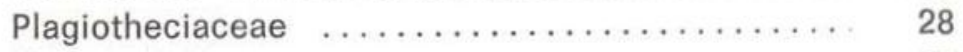

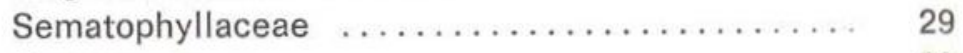

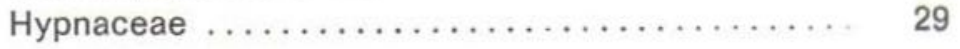

Hepaticae e Anthocerotae ................. 30

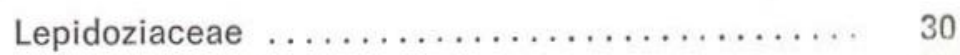

Calypogeiaceae $\ldots \ldots \ldots \ldots \ldots \ldots \ldots \ldots \ldots \ldots \ldots \ldots$ 


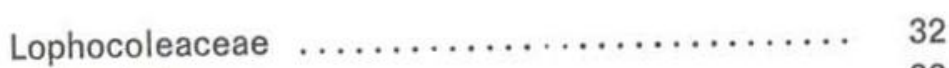

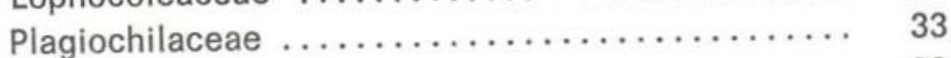

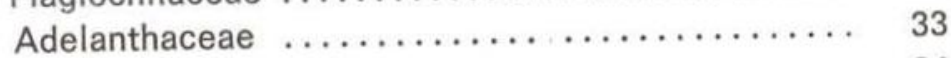

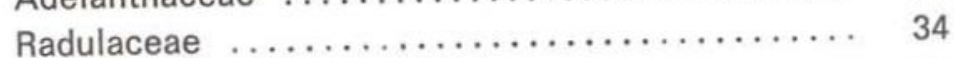

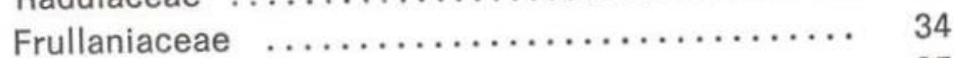

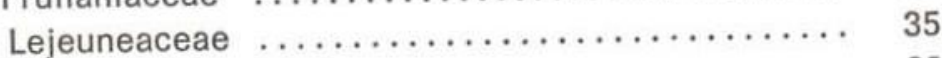

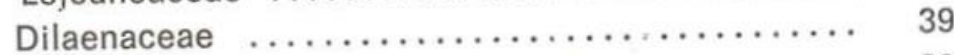

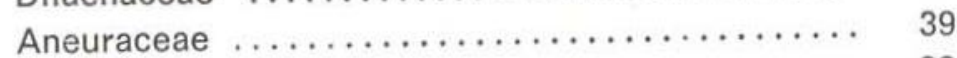

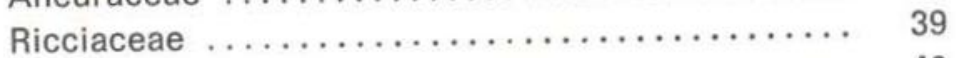

Anthocerotaceae $\ldots \ldots \ldots \ldots \ldots \ldots \ldots \ldots \ldots .40$

Classificação $\ldots \ldots \ldots \ldots \ldots \ldots \ldots \ldots \ldots \ldots \ldots \ldots \ldots \ldots \ldots \ldots \ldots \ldots \ldots \ldots$

Summary $\ldots \ldots \ldots \ldots \ldots \ldots \ldots \ldots \ldots \ldots \ldots \ldots \ldots \ldots \ldots \ldots \ldots \ldots \ldots$

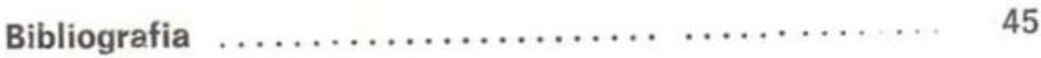




\section{INTRODUÇÃO}

Enbora a brioflora de Manaus e adjacências seja conhecida em maior ou menor detaIhe desde os trabaihos de Spruce (1884) e Mitten (1869), permanecem escassos os tratados didáticos que poderiam permitir uma apreciação dessas plantas tanto por botânicos gerais quanto estudantes. O autor faz este comentário procurando não destratar no mínimo que seja as publicações de briólogos, tais como Fulford (1963-1976), Gradstein (1975), Reese (1961), Schuster (1955) e outros - publicações que foram consultadas repetidamente no preparo do presente guia preliminar.

O propósito deste trabalho é apresentar as famílias e gêneros de briófitas freqüentemente encontrados e, dentro do possível, das espécies que são conhecidas em Manaus e adjacências. A maioria das espécies incluídas foi coletada pelo autor e seus estudantes, em 1974, em combinação com um curso de briologia dado no Instituto Nacional de Pesquisas da Amazônia. Uns poucos taxa citados na literatura como ocorrentes na área (mas não coletadas por nós) são também inciuídos.

Supondo-se que muitos leitores do guia não tenham tido o benefício de um treino formal em briologia, os termos técnicos são reduzidos a um mínimo, e os que são usados estarão definidos na maioria dos glossários botânicos ou em textos de morfologia de plantas, nas quais as briófitas são tratadas.

O leitor deverá estar atento para a natu. reza preliminar do guia e do tratamento necessariamente desigual atribuído a vários grupos. Algumas famílias (por exemplo, Adelanthaceae, Phyllodrepaniaceae, etc.) são mesmo pequenas ou apresentam relativamente poucos membros na região e nesses casos as chaves e notas descritivas são razoavelmente completas para o propósito de identificação. O mesmo pode ser cautelosamente dito a um grupo relativamente diverso como as Calymperaceae face, em grande parte, à inestimável assistência do Dr. W. D. Reese, um especialista nes. ta familia, que identificou muitas das nossas coleções, revisou e criticou a chave para espécies desta família. Ainda, a maior e mais diversa família da área, a Lejeuneaceae, permanece apenas parcialmente conhecida, e construir as chaves para todas as espécies locais näo foi possível.

ÁREA DE ESTUdo

As coleções, nas quais o presente trabatho é baseado, são oriundas, com raras exceções, da zona dentro de um raio de $150 \mathrm{~km}$ de Manaus, e enquanto praticamente todas as espécies variam além desta área, espera-se que a utilidade desse guia decresça com um aumento da distância a partir desta zona central dada a adição de outros taxa à flora não incluídos nas chaves.

A variação relativamente pequena na topografia da área de estudo contrasta com o grau de variação de habitats. A área total pode ser classificada como floresta tropical úmicia, sendo que boa parte da área é coberta pela floresta sempre-verde das terras firmes; entretanto, para entender a distribuição e ecologia de briófitas na região, é necessário subdividir essa classificação geral em certas partes componentes; assim, ao norte da área de estudo, nas proximidades do rio Lajes, é encontrada uma cobertura vegetal semelhante à "caatinga", na qual são encontradas pequenas escarpas e afloramentos rochosos, substratos que suportam alguns taxa de briófitas não encontradios em lugar algum. Também dignas de nota são as campinas, usualmente áreas isoladas de florestas esclerófilas rodeadas pela alta floresta úmida. As campinas suportam a mais distinta e, talvez, a mais 
interessante brioflora da área. Além disto, as várias florestas heterogêneas, plantações e campos abertos dão condiçöes de habitat onde são encontradas associações de espécies de briófitas que em alguns casos são distintas destes grupos de florestas primárias. Mesmo no ambiente urbano de Manaus, encontram-se espécies não coletadas em nenhum lugar da área de estudo. A esses habitats devem ser adicionadas as várzeas, igapós e terrenos alagados nas margens dos rios maiores todos fazendo parte do mosaico de ambientes dentro da área coberta pelo guia. A esta investigação geral de tipos de habitat podem ser somadas associações ou comunidades separadas de espécies que ocorrem dentro de um único habitat Isto é mais elegantemente demonstrado com referência à densa floresta úmida. Aqui, certos grupos de espécies ocorrem principalmente em solo exposto e sobre cupinzeiros, enquanto outros caracterizam restos de troncos derrubados, decorticados e ainda outros apresentam-se aderidos à casca de troncos vivos. Além disto, inúmeras espécies (particularmente Lejeuneaceae) são encontradas na superfície superior de folhas formando os "epiphylliae", um grupo diverso que, em várias maneiras, constitui o grupo mais morfologicamente especializado de todos.

\section{Uso Do GUIA}

O guia estả dividido em várias partes : chaves, descriçōes de famílias (com notas ecológicas), classificação dos gêneros tratados, bibliografia e ilustrações. As chaves são artificiais, na maioria das vezes, salvo para os casos onde um grupo de taxa relacionados (por exemplo, Leucobryaceae, Frullaniaceae, etc.) divide um ou mais caracteres distintos e óbvios, permitindo que sejam considerados juntos como um grupo. Se fosse construída uma chave inteiramente natural anularia, no julgamento do autor, o objetivo de permitir a fácil identificação dos taxa por não-briólogo. Uma chave natural teria requerido a introdução de muito mais pormenores técnicos e, em muitos casos, tanto de gametófito como esporófito. O leitor deve então notar que freqüentemente nas chaves gerais $e$, às vezes de gru- pos, os taxa são arranjados não de acordo com os seus relacionamentos naturais ou tılogenéticos, exceto pela sua comum, embora superficial, morfologia. A chave inicial para Classes de Bryophyta pode parecer, a prımeira vista, desnecessariamente detalhada, senão confusa. O estudante não deverá desencorajar-se por causa disto. Na prática, a tarefa de separar briófitas folhosas (formas talosas serão sempre Hepaticae ou Anthocerotae) nas suas Classes corretas não é tão difícil. Hepáticas folhosas, as únicas formas que podem ser confundidas com musgos, sempre apresentam uma simetria dorso-ventral corn filídios produzidos apenas em duas linhas (hepáticas com filídios dispostos radicalmente não ocorrem na área do estudo), com uma terceıra Iinha ventral de antigástrios ou sem ela. Os filídios de hepáticas nunca apresentam costas como ocorrem na maioria dos musgos.

\section{DESCRIÇŌES DE FAMÍlLIAS}

Esta é uma secção, na qual são apresentados, e, de forma abreviada, esses agrupamentos de caracteres que alinham certos gëneros ou um só gênero, em famílias. Esses limites de familia foram preparados principalmente para ajustar os taxa locais. Eles seriam, em muitos casos, sujeitos a explicações, se todos os gêneros e espécies constituintes fossem incluídos.

Anexas à descrição de cada família, estão algumas notas gerais ou ecológicas que objetivam familiarizar o leitor com a distribuição geográfica da família em questão, além de aspectos peculiarés de membros locais, isto é, habitat (s), substratos freqüentes, etc. Ocasionalmente, tentei sugerir taxa "ausentes", os quais não foram incluídos em nossa coleta na área. Não há razão para dúvidas de que coletas posteriores na vizinhança de Manaus, irão expandir a lista de espécies conhecidas na área. Dentro de algum tempo, o guia terá que passar por uma completa revisão.

\section{ILUSTRAÇÕES}

As ilustrações são incluídas para ajudar o leitor com o uso e a interpretação das chaves. Com respeito a essas, sempre é bom lembrar 
que não é possível cercar numa só ilustração toda a variação morfológica da espécie. Por isso, devemos resistir à tentação de crer que cada amostra que encontramos vá ter a morfologia representada com perfeição total pelas ilustrações. Esboços das formas características são incluídas para muitas espécies, entretanto pensando-se em economia de espaço, estes são, algumas vezes, omitidos, no caso de formas características (aspecto macroscópico) de um grupo de espécies relacionadas serem tão semelhantes que um esboço apenas é o suficiente.

\section{AgradeCIMENTOS}

Diversos briólogos auxiliaram o autor ná identificação de grupos problemáticos ou na revisão de partes do manuscrito. A esse respeito, expresso o meu agradecimento a : $\mathrm{Dr}$. H. Crum, Dr. P. A. Florschütz, Dr. S. R. Gradstein, Dr. Riclef Grolle, Dr. Sinske Hattori, Dr. Hiroshi Inoue, Dr. R. R. Ireland, Dr. R. A. Pursell, Dr. W. D. Reese, Dr. Paul Richards, Sr. D. M. Vital e Srta. Olga Yano. O autor deve um agradecimento muito especial à artista Srta. Rosemary Brant que fez boa parte das ilustrações macroscópicas deste guia. 


\section{CHAVES}

\section{AS CLASSES DE BRYOPHYTA}

1. Gametófito geralmente dorso-ventral e bilateral ou folhoso (e com duas filas laterais de filídios), ou taloso (sem talos e filídios diferenciados); filídios sem costa, embora vitas presentes às vezes; rizóides unicelulares e usualmente simples; óleo-corpos freqüentemente presentes nas células; seta mole, não precedendo a cápsuia em sua maturação; usualmente sem uma caliptra distinta; sem anel, opérculo ou peristômio, também sem estômatos na parede da cápsula (exceto no caso das Anthocerotae), cápsula normalmente deiscente por suturas longitudinais, tipica-

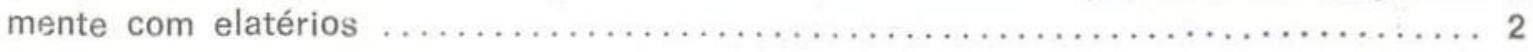

2. As células verdes do gametófito com alguns até muitos cloroplastos; com ou sem óleo-corpos; plantas talosas ou folhosas, sem estômatos; órgãos sexuais exógenos; cápsulas ovóides ou cilíndricas, tipicamente sem (ou com 4) válvuias, sem columela ou estômatos; seta presente, alongada ou curta (às vezes reduzida a um vestígio) ............ Classe Hepaticae

2'. As células verdes do gametófito com um só cloroplasto cada uma; sem óleo-corpos; plantas talosas, prostradas, o lado ventral com estêmatos \pm distintos; arquegônias sumidas, anterí. dios endógenos; esporófito alongado-cilindrico, deiscente por duas suturas longitudinais; columela e estômatos presentes; sem seta ..................... Classe Anthocerotae

1'. Gametófito sempre folhoso, geralmente com uma simetria radial, às vezes, dístico ou com os filídios aplanados e num só plano; filídio com 1-2 costas ou ocasionalmente sem costa ou com a costa bem reduzida; rizóides septados e usualmente ramificados; sem óleo-corpos; seta firme, pigmentada, maduro antes da maturação da cápsula; caliptra normalmente distinta, caduca ou mais raramente persistente; cápsula operculada, usualmente com peristômio (os dentes, às vezes, frágeis e ausentes ou quebrados ou mal formados); sem anel ou com ele; estomatos freqüentes na parede da cápsula; sem elatérios.

Classe Musci

\section{MUSCI}

\section{Chave geral}

1. Piantas esbranquiçadas quando secas; filídios de dois tipos de células regularmente distribuídas - umas grandes, vazias, incolores - outras pequenas, estreitas, verdes $\ldots \ldots \ldots \ldots \ldots 2$

2. Filídios com um só estrato de células, as células incolores com fibrilas helicoidais; sem

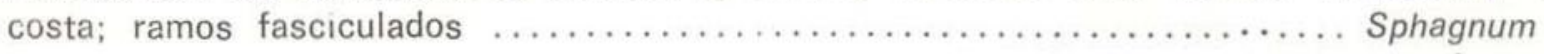
palustre L.

2' Filídios com dois ou mais estratos de células, tendo as células grandes e incolores acima e abaixo das células pequenas e verdes; com uma costa larga, limbo restringido à base do filí-

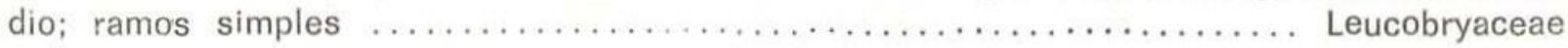

1 1'. Plantas de várias cores, amarelas até verdes ou verde claras, às vezes ruivas até pardas; filídios com um ou mais tipos de células, mas nunca de dois tipos (incolores e verdes) regularmente distribuídos

3. Filídios obviamente dispostos em filas (em duas ou mais filas distintas) ou aplanados e ocorrendo \pm num só plano Chave A 
3'. Filídios espiralados ou irregularmente inseridos, nunca em filas distintas ou aplanadas. 4

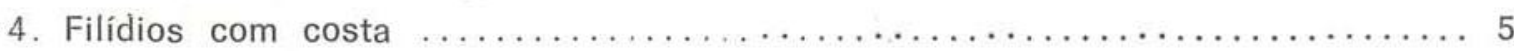

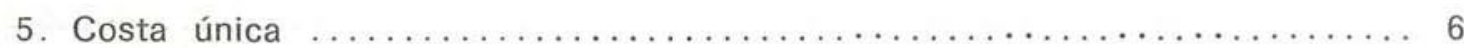

6. As células interiores na parte basal do filídio muito inchadas e hialinas, bem distin tas das outras células pequenas e vercies na parte superior do filidio ...

Calymperaceae (em parte)

6'. As células interiores na parte basal do filídio variável, \pm distintas das células superiores da lâmina mas não inchadas e hialinas $\ldots \ldots \ldots \ldots \ldots \ldots \ldots \ldots$

7. Margem do filídio espessada cu alada .................. Chave B

7'. Margem do filídio não espessada nem alada embora, às vezes, involuta ou revolutosa .................................... 8
8. Células do filídio papilosas
Chave C
8'. Células do filídio lisas
Chave D

5'. Costa dupla alcançando meia-lâmina ou mais para lá $\ldots \ldots \ldots \ldots \ldots \ldots \ldots$.

9. Células do filídio lisas ......................... Chave $E$

9' Células do filídio papilosas $\ldots \ldots \ldots \ldots \ldots \ldots \ldots \ldots \ldots \ldots \ldots \ldots \ldots \ldots \ldots$ Chave $F$

4'. Filídios sem costa ou costa curta, bifurcada e restrita à base do filídio ....... 10

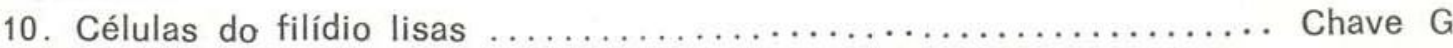

10'. Células do filídio papilosas $\ldots \ldots \ldots \ldots \ldots \ldots \ldots \ldots \ldots \ldots \ldots \ldots$ Chave $\mathrm{H}$

Chave A

\section{Musgos com Filídios Dísticos ou Aplanados e Dispostos \pm num só Plano}

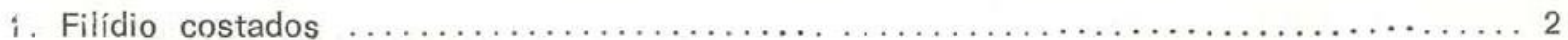

2. Costa dupla, forte, alcançando mais para lá da meia-lâmina $\ldots \ldots \ldots \ldots \ldots \ldots \ldots . \ldots \ldots$

3. Células com 1-2 papilas sobre o lúmen....................... Callicostella

spp.

3'. Células papilosas na parte apical (papilas não sobre o lúmen)...$\ldots \ldots$.... Hookeriopsis parkeriana

(Hook.) Jaeg.

2'. Costa simples

4. A lâmina dupla (conduplicada) na parte basal e adaxial do filídio

Fissidens spp

4'. A lâmina simples por todo o filídio

5. Ápice do filídio largo, truncado Neckeropsis spp

5'. Ápice do filídio agudo até breve-acuminado

6. Células papilosas até mamilosas . 7

7. Filídios dispostos em duas filas, margens agudamente recurvadas .. Mniomalia viridis (Mitt.)

C. Muell.

7'. Filídios dispostos em $5-$ (ou raramente 4) filas, margens planas Macromitrium pentastichum

C. Muell. 


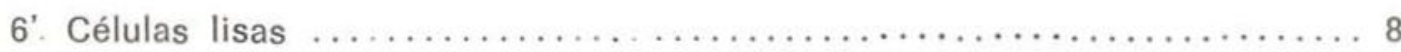

8. Talos folhosos-aplanados; filídios fortemente falcados, assimétricos ......... Phyllodrepanium. falcifolium (Schwaegr.) Crosby

8'. Talos folhosos-roliços; filidios oblongo-lanceoiados, simétricos .. Pireella pohlii (Schwaegr.) Card.

1'. Filídios sem costa ou com a costa curta, bifurcada e restringida à base do filídio ..... 9

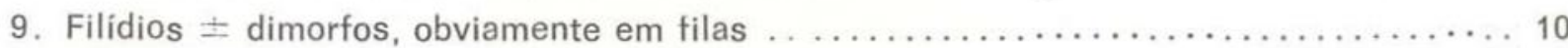

10. Filídios claramente dimorfos, aqueles da fila ventral muito menores do que os outros das filas laterais; tipicamente sobre troncos vivos ou caídos e mortos de vários tipos de

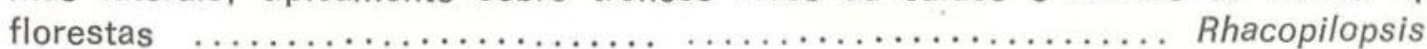

trinitensis (C. Muell)

Britt. ex Dix.

10'. Filídios escassamente dimorfos, aqueles das filas dorsais um pouco menores do que os outros das filas laterais, tipicamente sobre galhos finos e folhas de lugares úmidos...

Crossomitirum patrisiae (Brid.)

C. Muell.

9'. Filídios aplanados (os talos fo!hosos com aspecto pranchado), monomorfos, não dispostos

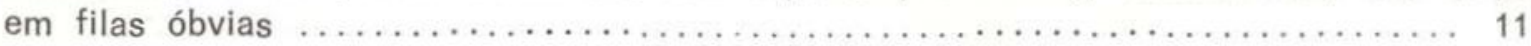

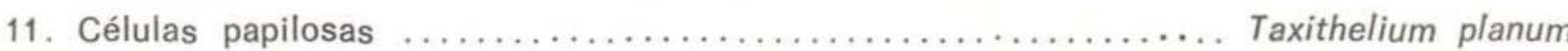
(Brid.) Mitt.

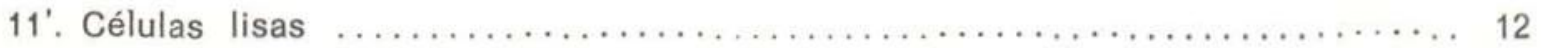

12. Filídios oblongo-ovóides, breve-acuminados, muitos com um dos dois lados largamente dobrados para baixo Pilosium chlorophyllum

(Hornsch.)

C. Muell. in Broth.

12'. Filídios ovóide-lanceolados, acuminados, a lâmina não dobrada para baixo Isopterygium spp

\section{Chave B}

\section{Musgos com Filídios Unicostados e com as Margens da Lâmina Espessadas ou Aladas}

1. Filidios amplamente ligulados, ápice largo, apiculado, as margens superiores subinteiras até del. gada e remotamente denticuladas; sem filídios propagulíferos Syrrhopodon xanthophyllus Mitt.

1'. Filidios lanceolados ou oblanceolados, ápice largamente agudo até agudo ou acuminado, as mar gens superiores distintamente serreadas; filídios propagulifercs freqüentes $\ldots \ldots \ldots \ldots 2$

2. Cancelinas estendendo-se até os ombros ou perto deles, usualmente intactas e persistentes Syrrhopodon rigidus Hook. et Grev. 
2'. Cancelinas acabando muito abaixo dos ombros, usualmente destruídas e efêmeras .. 3

3. Margens na parte inferior do filídio inteiras ou \pm irreguiarmente serreadas, os dentes nem patentes nem recurvados, costa do filídio normal usualmente com 2-vários dentes conspícuos acima pelo lado dorsal, cancelinas alcançando $1 / 3-1 / 2$ do comprimento da lâmina

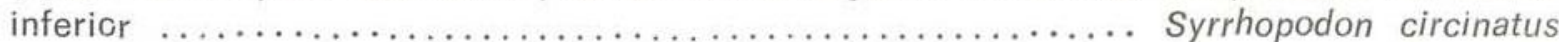

(Brid.) Mitt.

3'. Margens na parte inferior do filídio (ao menos em alguns filídios) \pm regularmente denta das ou serreadas com alguns dentes patentes ou recurvados, costa do filídio normal lisa ou ocasionalmente com 1-2(-3) dentes baixus acima pelo lado dorsal, cancelinas mui. to curtas, restringidas à base da lâmina inferior ............... Syrrhopodon

hornschuchii Mart.

Chave C

\section{Musgos com Filídios Unicostados e Células Papilosas}

1. Margem do filídio com dentes emparelhados, costa percurrente até excurrente, papilas se proje tando da parte apical das células ......................... Philonotis uncinata

(Schwaegr.) Brid.

1. Margem do filídio inteira ou levemente denticulada, papilas sobre o lúmen das células .. 2

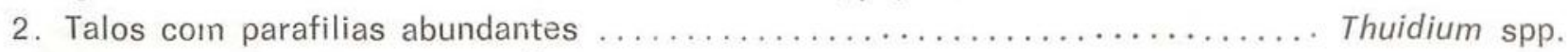

2'. Talos sem parafilias ou parafilias escassas ............................. 3

3. Filídics ovado-lanceolados, ápice agudo, papilas pequenas, células alares quadráticas ....

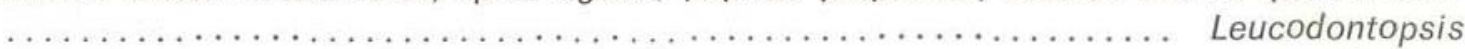
geniculata (Mitt.) Crum et Steere

3'. Filídios ianceolado-iiguiados, ápice obtuso-apiculado, papilas largas, arredondadas, células alares alongadas Macromitrium pellucidum Mitt.

\section{Chave D}

\section{Musgos com Filídios Unicostados e Células Lisas}

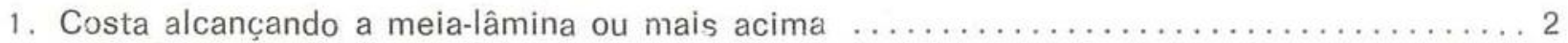

2. A base do filídio cordiforme, abraçando o talo, ápices dos filídios delgados até piliformes. células alares alongadas, estreitas Meteoriopsis patula (Hedw.) Broth.

2'. A base do filidio ovóide, não abraçando o talo, ápices dos filídics agudos até acuminados, células alares quadráticas, em muitas filas

Stereophyllum leucostegum (Brid.) Mitt.

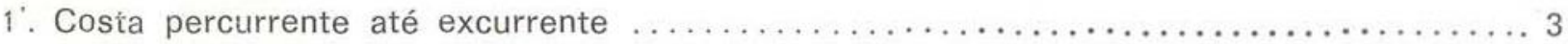

3. Costa larģa, de $1 / 3-1 / 2$ da largura da lâmina íntegra ................ Campylopus spp.

3'. Costa estreita, muito menos de $1 / 3$ da largura da lâmina íntegra $\ldots \ldots \ldots \ldots \ldots 4$

4. A.s células marginais da parte inferior do filidio alongadas, hialinas, formando uma borde conspícua

Groutiella

mucronifolia (Hook. et Grev.) Crum et Steere 
$4^{\prime}$. As células marginais ou não alongadas ou não formando uma borda conspícua . . 5

5. Plantas dendróides e usualmente (e abundantemente) ramificadas, a base do filídio auriculada

Pireella pohlii

(Schwaegr.) Card.

5'. Plantas eretas mas não dendróides, simples ou escassamente ramificadas, a base do filídio ovóide ou côncavo até largamente cuneiforme ............... 6

6. Filídios ereto-imbricados até ereto-patentes, os mais largos abaixo da meia-lâmina

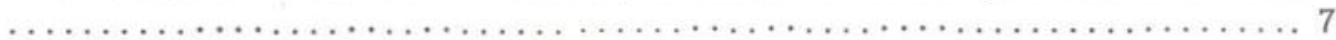

7. Filídios ereto-imbricados ou falcados e \pm homômalos quando secos; cápsulas eretas, retas, os dentes do peristômio numa série, rachados até mais abaixo do meio

Dicranella

hilariana (Mont.)

Mitt.

7'. Filídios imbricados até ereto.patentes quandio secos; cápsulas inclinadas até pêndulas; os dentes do peristômio em duas séries, não rachados .. Bryum spp.

6' Filídios amplamente envoltos quando secos, os mais largos no meio ou mais acima

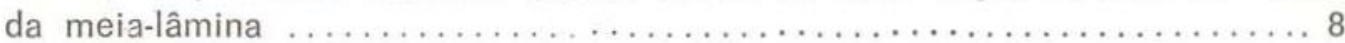

8. Margens dos filídios inteiras; peristômio presente, os dentes espiraladamente

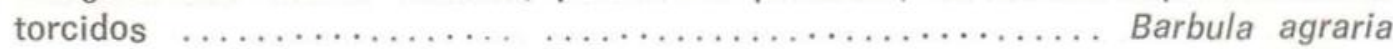

Hedw.

8'. Margens dos filidios serreadas até denticuladas perto do ápice da lâmina; peristômio ausente Hyophila tortula

(Schwaegr.)

Hampe

\section{Chave E}

\section{Musgos com Filídios Bicostados e Células Lisas}

1. Plantas frondosas; filídios estreitos até largamente ovados

Pilotrichum spp.

1'. Plantas rasteiras; filídios estreitamente ovóide-lanceolados, longo-acuminados, fortemente falcado-secundiformes Hookeriopsis spp.

\section{Chave $F$}

\section{Musgos com Filídios Bicostados e Células Papilosas}

1. Papilas saindo da parte apical das células

Hookeriopsis parkeriana (Hook.) Jaeg

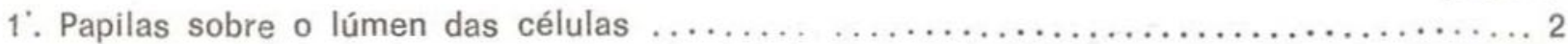

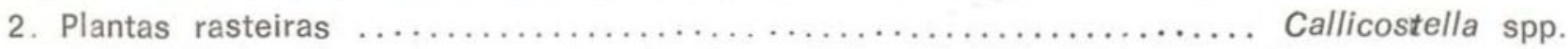

2'. Plantas frondosas; o talo primário rasteiro mas os secundários frondosos e livres do substrato Pilotrichum spp.

\section{Chave G}

Musgos com Filídios Ecostados (ou com a Costa Curta, Bifurcada e Restringida à Base do Filídio) e Células Lisas 


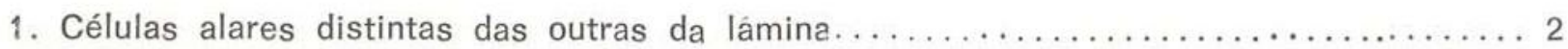

2. Células aiares pequenas, quadráticas até subquadráticas, \pm conspícuas, não tingidas $\cdot 3$

3. Plantas pequenas (até $1 \mathrm{~cm}$ de comprimento); filídios ereto-patentes, $500-750 \mu \mathrm{m}$ de comprimento, células alares pequenas, quadráticas, distintas das células alongadas da lâmina; cápsula delgada, cilíndrica, reta peristômio numa só série ....Pterogonidium pulchellum (Hook.) C. Muell.

3. Plantas de tamanho variável; filídios geralmente patentes, a região alar de umas poucas células subquadráticas, com uma fila conspícua ao longo da base do filídio de células alongadas e retangulares; cápsula \pm curvada, peristômio de duas séries... Isopterygium spp.

2'. Células alares infladas, conspícuas, freqüentemente tingidas (amarelas ou alaranjadas até

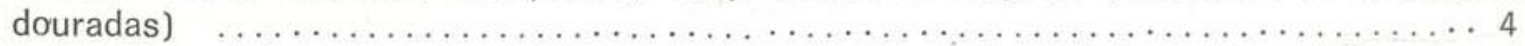

4. Peristômio de uma só série $\ldots \ldots \ldots \ldots \ldots \ldots \ldots \ldots \ldots \ldots \ldots \ldots \ldots \ldots \ldots \ldots$ Meiothecium

revolubile Mitt.

4'. Peristômio de duas séries $\ldots \ldots \ldots \ldots \ldots \ldots \ldots \ldots \ldots \ldots \ldots$ Sematophyllum spp.

$1^{\prime}$ Células alares escassamente distintas das outras células da lâmina $\ldots \ldots \ldots \ldots \ldots .5$

5. Filídios ereto-patentes, células tusíormes, extremamente laxas, paredes delgadas, iargura 25-30 $\mu \mathrm{m} \times 100-200 \mu \mathrm{m}$ de comprimento; caliptra parcamente pilosa ....... Leucomium

lignicola

Spruce ex Mitt.

5'. Filídios patentes especialmente as dos ramos, \pm falcados, células laxas, ovado-romboidais, largura 8-15 $\mu \mathrm{m} \times$ 60-75 $\mu \mathrm{m}$ de comprimento; caliptra glabra $\ldots \ldots \ldots \ldots$. Vesicularia

amphibola

Chave H

(Spruce) Broth.

\section{Musgos com Filídios Ecostados e Células Papilosas}

1. Células pluripapilosas, papilas arranjadas numa fila sobre o lúmen, células alares quadráticas,

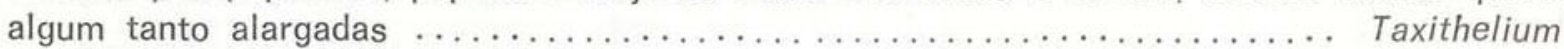
planum (Brid.)

Mitt.

1'. Células unipapilosas, células alares consideravelmente alargadas, elípticas $\ldots \ldots \ldots 2$

2. Plantas até $5 \mathrm{~cm}$ de comprimento, crescendo em coxins laxos sobre galhos a troncos; filídios patentes até esquarrosos, margens inteiras, ponta subtubulosa ....... Acroporium

guianense (Mitt.)

Broth.

2'. Plantas geralmente até $3 \mathrm{~cm}$ de comprimento, arrastando-se pelo chão ou sobre troncos caídos, ocasionalmente sobre troncos e galhos vivos; filídios patentes até laxamente ascendentes, margens serruladas até serreadas ou denticuladas, ponta plana (em algumas espécies as pontas são flexuosamente torcidas $) \ldots \ldots \ldots \ldots \ldots \ldots \ldots \ldots$ Trichosteleum spp.

\section{HEPATICAE E ANTHOCEROTAE}

\section{Chave geral}

1. Plantas talosas, obcordiformes ou mais freqüentemente alongadas, liguiadas, simples ou ramificadas, margens planas, onduladas ou debilmente lobuladas $\ldots \ldots \ldots \ldots \ldots \ldots \ldots \ldots$ Chave $A$

$1^{\prime}$. Plantas folhosas (o corpo da planta dividido em talos $e$ filídios) $\ldots \ldots \ldots \ldots \ldots \ldots \ldots \ldots .2$ 
2. Filídios filiformes ou divididos até a base em segmentos filiformes .......... Chave B

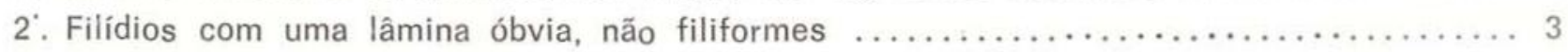

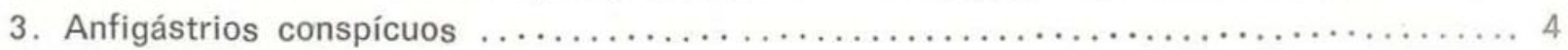

4. Filídio condupiicado, som um lóbulo ventral .................... Chave C

4'. Filídio sem lóbulo ventral (não conduplicado) $\ldots \ldots \ldots \ldots \ldots \ldots \ldots$ Chave D

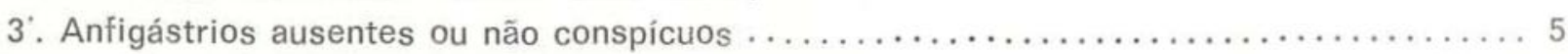

5. Filídio conduplicado, com um lóbulo ventrai $\ldots \ldots \ldots \ldots \ldots \ldots \ldots \ldots \ldots \ldots$ Chave $E$

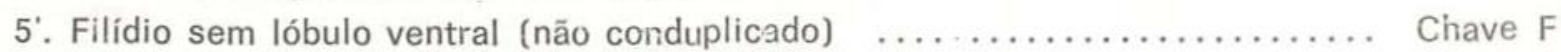

\section{Chave A}

\section{Plantas Talosas}

1. Células verdes dos talos com um só cloroplasto grande cada uma; esporófito alongado-cilín-

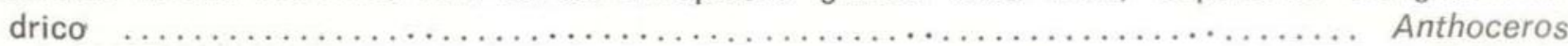

spp.

1'. Células verdes dos talos com vários cloroplastos pequenos cada uma; cápsulas dos esporófitos

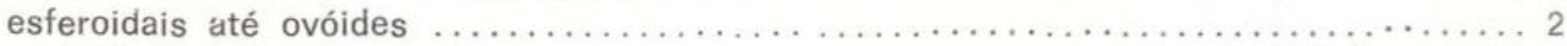

2. Talo obcordiforme, espesso com um encaixe mediano pelo lado dorsal e com escamas alon. gadas, púrpuras pelo lado ventral; plantas aquáticas, flutuantes ......... Ricciocarpus natans L.

2'. Talo alongado, não espesso, sem um encaixe dorsal, o lado ventrai com rizóides ou sem ele,

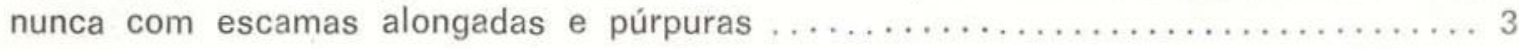

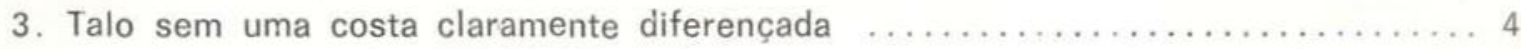

4. Lóbulos do talo estreitos (usualmente menos de $2-3 \mathrm{~mm}$ de largura); ramificaçōes re gular, pinalada, bipinalada ou tripinalada .................. Riccardia spp.

4'. Lóbulos do talo \pm largos (usualmente mais de $5 \mathrm{~mm}$. de largura); ramificação irre-

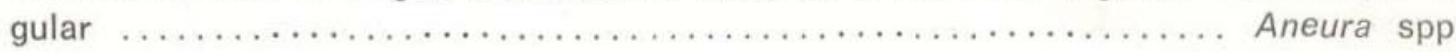

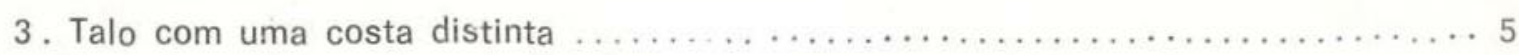

5. Margens do talo irregularmente serruladas, freqüentemente com papilas mucilagino sas, alongadas e estreitas ao longo da margem .............. Pteropsiella serrulata Spruce ex Steph.

5'. Margens do talo inteiras, papilas mucilaginosas (quando presentes) pediceladas e

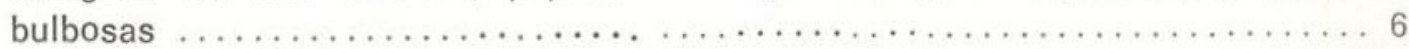

6. Margens do talo não lobuladas, nunca com papilas mucilaginosas; invólucros curto-tubulares, cupuliformes

Pallavicinia lyellii (Hook.)

S. F. Gray

6'. Margens do talo freqüentemente lobuladas, com papilas mucilaginosas marginais; invólucros escamoso-laciniados

Symphyogyna

brongniartii Mont.

\section{Chave B}

\section{Plantas com Filídios Filiformes ou Divididos até a Base em Segmentos Filiformes}


1. Filidios da planta de um segmento cada uma

Arachniopsis

pecten Spruce

$1^{\prime}$. Filidios da planta de dois ou mais segmentos cada uma $\ldots \ldots \ldots \ldots \ldots \ldots \ldots \ldots . \ldots \ldots$

2. Células dos segmentos quadráticas até curto-retangulares, 1-2:1, cutícula escabroso-verrugada

Microlepidozia

verrucosa (Steph.)

Fulford

2'. Células dos segmentos retangulares, $3-8: 1$, cutícula lisa $\ldots \ldots \ldots \ldots \ldots \ldots \ldots . \ldots$

3. Anfigástrios reduzidos, de duas papilas adjacentes; filídios de dois segmentos $\ldots . . .$.

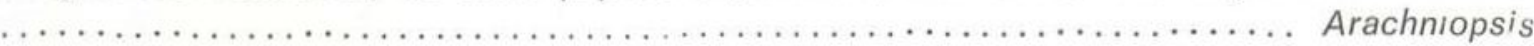
coactilis

Spruce

3'. Anfigástrios alcançando até $1 / 2$ do comprimento dos fiídios, filídios e anfigástrios de 2-4 segmentos

Telaranea

sejuncta

(Aongstr.)

Chave C

S. Arnell

\section{Plantas Folhosas com Anfigástrios e Lóbulos}

1. Lóbulos com o eixo mais comprido paralelo ao talo ou quase assim, livres dos filídios salvo

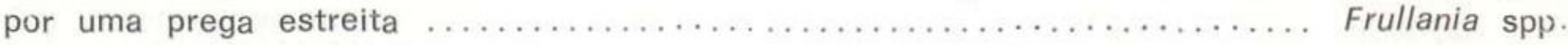

1 . Lóbulos com o eixo mais comprido paralelo às margens ventrais dos filídios, largamente presos aos filídios

Lejeuneaceae

(em parte)

\section{Chave D}

\section{Plantas Folhosas com Anfigástrios mas sem Lóbulos}

1. Filidios com uma ala ou carena no lado ventral; filídios eqüitantes, imbricados

Micropterygium spp.

1. Filídios sem alas ou carenas; filídios adjacentes até imbricadas mas nunca eqüitantes .. 2

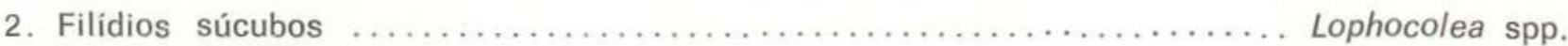

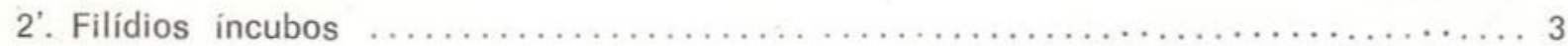

3. Talos dicotomicamente ramificados, usualmente com ramos flageliformes ventrais levando

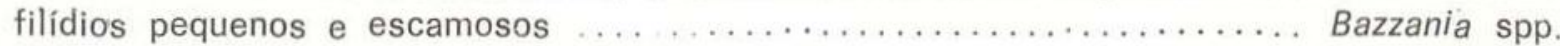

3'. Talos simples ou irregularmente ramificados, raramente com ramos flageliformes ventrais Calypogeia spp.

\section{Chave E}

\section{Plantas Folhosas com Lóbulos mas sem Anfigástrios}

1. Lóbulos angulados, rizóides em eachos pequenos limitados às faces ventrais dos lóbulos .....

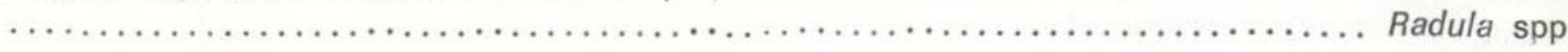


1'. Lóbulos ovalados ou reduzidos a uma dobra linear, rizóides em cachos pequenos saindo do

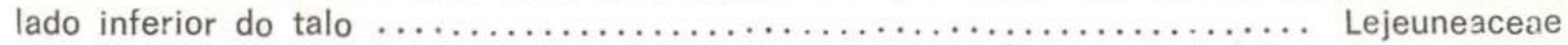

(Paradoxae, Aphylliae)

\section{Chave F}

\section{Plantas Folhosas sem Anfigástrios (ou Anfigástrios não Conspícuos) e sem Lóbulos}

1. Filídios fortemente reduzidos até 1-3 células com papilas mucilaginosas ... Regredicaulis serrus (Spruce) Fulford

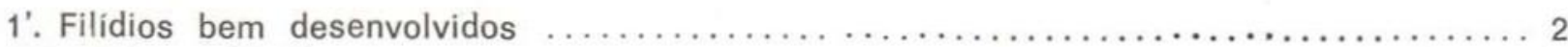

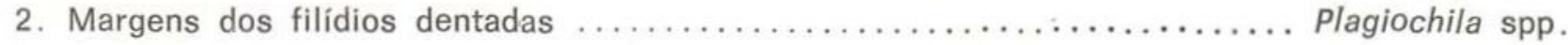

2'. Margens dos filídios inteiras, ápice até bífido ou não dividido $\ldots \ldots \ldots \ldots \ldots \ldots \ldots$

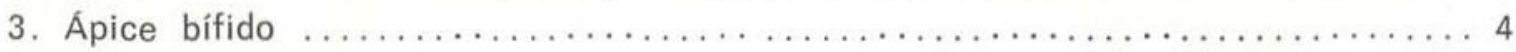

4. Filídios fortemente carenados, células quadráticas com trigones grandes, inchados cutícula verrucoso-papilosa $\ldots \ldots \ldots \ldots \ldots \ldots \ldots \ldots \ldots \ldots$. Mytilopsis

albifrons Spruce

4'. Filídios planos até escassamente carenados, células variáveis, paredes uniformemente espessadas, cutícula lisa até verruculosa ............... Regredicaulis

serrus (Spruce)

Fulford

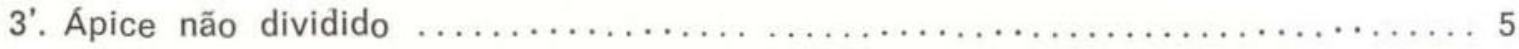

5. Margens dos filídios com papilas mucilaginosas, alongado-horizontais .. Zoopsis integrifolia

(Spruce) Steph.

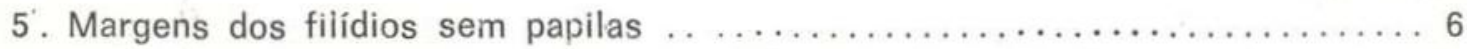

6. Filídios sub-retangulares até longamente ovado-truncados, margens crispantes ou

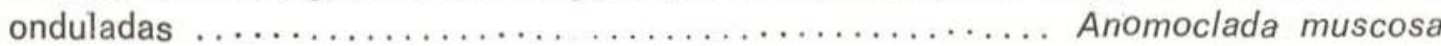

Spruce

6'. Filídios ovóides até orbiculares, margens planas ou ligeiramente involutas ......

Odontoschisma spp 


\title{
DESCRIÇÃO DAS FAMILIAS COM NOTAS AUXILIARES
}

\author{
MUSCI
}

\section{SPHAGNACEAE}

Plantas variáveis, grandes ou medianas geralmente de lugares molhados, ramos usualmen. mente fasciculados dispostos em espirais pelo talo, no ápice do talo densamente inseridos formando capítulos. Filídios dos talos e ramos espiralmente dispostos, sem costa, lâmina com um só estrato de células. Células de dois tipos: umas grandes, hialinas, fibrilosas e porosas alternando com outras pequenas e clorofiladas. Os filídios dos talos distintos da dos ramcs, menos densas. Cápsula giobosa, operculada, gimnóstoma, elevada um pouco acima dos filídios por um pseudopódio.

É uma família monotípica sendo Sphagnum o único gênero. São plantas na maior parte das latitudes subpolares, embora haja umas poucas espécies que ocorrem nos trópicos.

Localmente, encontra-se a espécie Sphagnum palustre crescendo sobre as bordas arenosas e moihadas dos igarapés.

\section{Fissidentaceae}

Plantas usualmente pequenas, gregárias, mormente eretas, simples ou parcamente ramificadas. Filídios lanceolados ou ligulados, equitantes, dispostos em duas filas distintas, cada filídio simples acima (lâmina apıcal e dorsal) mas composta abaixo e pelo lado adaxial de duas metades conduplicadas (lâmina vaginada). Costa simples, forte, percurrente até brevemente excurrente. Células laxas até densas, quadráticas ou arredondadas, lisas. mamilosas ou papilosas. Cápsula emersa, terminal ou lateral. Peristômio simples. dentes 16 , rachados até a metade ou mais abaixo. Caliptra pequena, cuculiforme.

É uma tamilia quase cosmopolita de 1-4 gêneros dependendo do ponto de vista taxonômico. Só Fissidens ocorre na área do guia.

São plantas típicas dos solos, termiteiros, paus podres e troncos vivos

\section{Fissidens}

1. Filidios totaimente elimbados, células da lâmina lisas até mamilosas ........ Fissidens prionodes Mont.

1'. Filidios parcial ou totalmente limbados (borda hiaiina às vezes intramarginal), células da lâmina

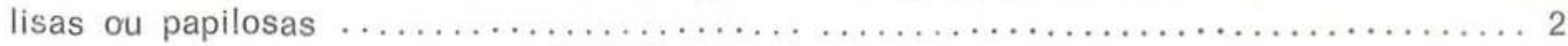

2. Borda hialina alcançando até o ápıce do filídio ou perto, as células da lâmina apical e dorsa! lisas, as da lâmina vaginada ainda maiores e pelúcidas ................ Fissidens

kegelianus

C. Muell.

2'. Borda hialina restringida à base da lâmina vaginada, células do filídio distintas ou densas, uni.

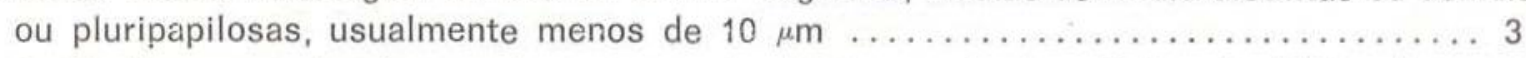

3. Borda marginal, alcançando o cume da lâmina vaginada, células do filídio distintas, unipapilosas, paredes delgadas, $8-10 \mu \mathrm{m} \ldots \ldots \ldots \ldots \ldots \ldots \ldots \ldots \ldots \ldots \ldots \ldots \ldots \ldots \ldots$ Fissidens

C. Muell. 
3'. Borda tipicamente intramarginal, usualmente restringida à parte basal da lâmina vaginada, células do filídio densas, fracamente pluripapilosas, 4-8 $\mu \mathrm{m} \ldots \ldots \ldots$. . Fissidens

elegans Brid.

\section{DICRANACEAE}

Plantas pequenas até robustas, em tapetes, ou coxins, simples ou escassamente ramificadas, os talos freqüentemente tomentosos. Filídios variáveis, tipicamente lanceolados, muitas vezes falcado-secundiformes. Costa simples, forte, percurrente até excurrente. Células alonģadas na região da base do filídio, as células alares freqüentemente infladas, tingidas ou incolores, para o ápice mais curtas, usuaimente lisas, mais raramente mamilosas cu papilosas. Cápsula emersa, curvada ou reta. Peristômio simples, usualmente 16 dentes, bifurcados até a metade, estriados verticalmente abaixo pela maior parte. Caliptra cuculiforme às vezes, franjada na base .

É uma família grande de ampla distribuição e representada localmente pelos gêneros Campylopus e Dicranella.

A maioria de nossas espécies são plantas de solos inorgânicos e de lugares soalheiros

\section{Campylopus}

1. Filídios curtos, até $4 \mathrm{~mm}$. de comprimento, fortemente adpressas ao talo

Campylopus

surinamensis

C. Muell.

$1^{\prime}$. Filídios mais longos, $5-8 \mathrm{~mm}$. de comprımento, mais laxos $\ldots \ldots \ldots \ldots \ldots \ldots \ldots \ldots \ldots \ldots \ldots$

2. Filídios \pm uniformemente distribuídos ao longo do talo $\ldots \ldots \ldots \ldots \ldots \ldots \ldots \ldots$

3. Células perto da costa e justamente acima da região alar retangulares com paredes lisas até debilmente porosas

Campylopus

savannarum (C. Muell.)

Mitt.

3'. Células perto da costa e justamente acima da região alar retangulares mas com paredes

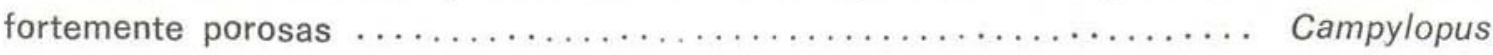

sprucei Mitt.

2'. Filídios desigualmente distribuídos ao longo do talo

Campylopus

trachyblepharon

(C. Muell.) Mitt.

\section{LEUCOBRYACEAE (')}

Plantas pequenas até moderadamente rcbustas, esbranquiçadas ou verde esbranquiçadas quando secas (alguns membros podem mostrar uma cor rosada ou púrpura nas partes basais dos filídius), usualmente em coxins densos. Filídios ovado-lanceolados, retos ou patentes, às vezes, falcado-secundiformes. Costa larga, bem desenvolvida, mostrando em secção transversai 2 ou mais estratos de células grandes, hialinas (leucocistos) acima e abaixo dum só estrato (raramente mais) de células pequenas, verdes (clorocistos). Células laxas, quadráticas até alongadas. Cáp. sula tipicamente emersa, reta ou curvada. Peristômio simples, dentes 8 ou 16, inteiros ou rachados, opérculo freqüentemente rostrado. Caliptra cuculiforme.

É uma família tropical em sua maior parie. Na área do guia encontram-se dois gêneros, Leucobryum e Octoblepharum. São plantas de uma variedade de substratos e ambientes alcançando a sua maior diversidade nas campinas.

(1) - As chaves para esta família foram adaptadas e-modificadas de Florschütz (1964). 
Dois gêneros mais podem ocorrer nas adjacências de Manaus, o Leucophanes que pelo lado dorsal da costa tem um pequeno grupo de células com paredes bem espessadas (estereideos) e o Ochrobryum em que a cápsula é imersa entre os filídios e falta um peristômio.

\section{Chave para os Gêneros}

1. Margens dos filídios enroladas formando acima uma ponta tubulosa ou subtubulosa, clorocistos 4-angulares em secção transversal; cápsulas inclinadas, assimétricas ........ Leucobryum

1'. Margens dos filídios \pm planas, filídios ligulados, ápice obtuso até largamente agudo ou acuminado, clorocistos 3-angulares em secção transversal; cápsulas retas, simétricas .... Octoblepharum

\section{Leucobryum}

1. Filídio em secção transversal perto da base mostrando dois estratos de células hialinas; filídios tipicamente falcados secundiformes, às vezes, ereto-patentes e \pm crispados .. Leucobryum

martianum

(Hornsch.)

Hampe ex C. Muell

1'. Filidios em secção transversal perto da base mostrando mais que dois estratos de células hialinas, filídios fortemente flexuoso-crispados, às vezes, debilmente falcados, secundiformes ......

Leucobryum

crispum C. Mue!!

\section{Octoblepharum}

1. Costa em secção transversal perto do meio da lâmina \pm equilateralmente triangular, os cantos arredondados

1'. Costa em secção transversal perto do meio da lâmina \pm achatado, biconvexo 2

2. Filídio em secção transversal perto do ápice mostrando 2 estratos de células hialinas; peris-

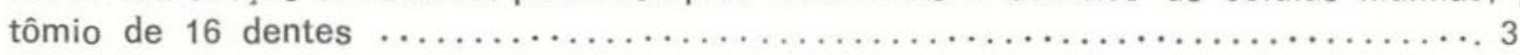

3. Ápice do filídio obtuso, apiculado e asperamente dentado ........ Octoblepharum pellucidum C. Muell.

3'. Ápice do filídio acuminado, ondulado

Octoblepharum cocuiense Mitt.

2'. Filídio em secção transversal perto do ápice mostrando 4 estratos de células hialinas; peris-

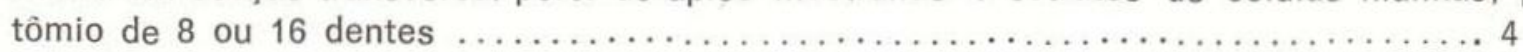

4. Filídics quando secos lustrosos, as partes apicais com cor de palha, mas escuras até roxo-pardas nas partes basais $\ldots \ldots \ldots \ldots \ldots \ldots \ldots \ldots \ldots \ldots \ldots \ldots \ldots \ldots$ Octoblepharum stramineum Mitt

4'. Filídios verde-esbranquiçados ou amarelos claros, às vezes rosados ou púrpuros perto das

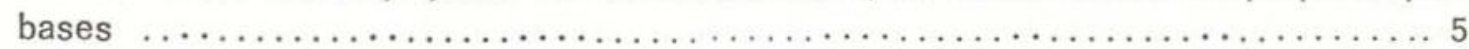

5. Filídios frágeis, as pontas freqüentemente quebradas, ápice obtuso, embotadamente apiculado, células no meio superior da lâmina irregulares e um tanto pequenas (20-45 $\mu \mathrm{m}$ de comprimento); peristômio de 16 dentes arranjados em 8 pares .. Octoblepharum

pulvinatum

(Dozy et Molk.)

Mitt. 
5'. Filídios não frágeis, as pontas usualmente presentes, ápice obtuso ou agudo, células no meio superior da lâmina, retangulares e um tanto grandes (50-80 $\mu \mathrm{m}$ de comprimen-

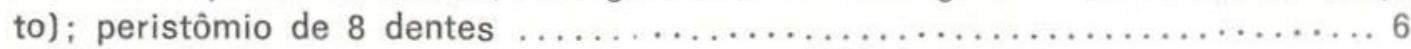

6. Ápice do filídio \pm obtuso e dentado em sua maior parte, células na parte central da lâmina retangulares, cápsula ovóide, seta com menos de $1 \mathrm{~cm}$. de comprimento .. Octoblepharum albidum Hedw

6'. Ápice do filídio inteiro em sua maior parte, células na parte central da lâmina \pm qua. dráticas, cápsula cilíndrica, seta com mais de $1 \mathrm{~cm}$. de comprimento ............

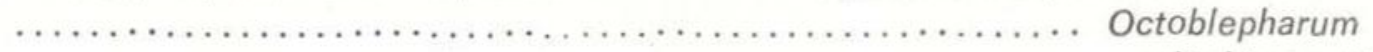

cylindricum Mont

\section{CALYMPERACEAE}

Plantas pequenas até moderadamente rcbustas, verdes ou, às vezes, rúfulas, crescendo em coxins ou tufos. A parte basal do filidio frequientemente hialina, \pm abraçando o talo, a parte superior variável. Costa forte, alcançando até o ápice do filídio ou perto dele, freqüentemente com propágulos septados na região apical. As células da parte superior do filídio tipicamente pequenas, densas, usualmente papilosas ou mamilosas, raramente lisas, células da parte inferior ou inchadas e hialinas (as cancelinas) ou estreitas $e \pm$ espessadas (as teniolas), ocorrendo estas últimas ou na margem da lâmina ou, às vezes, numa posição intramarginal, sendo restringidas as teníolas à região dos ombros ou um pouco acima. Cápsula tipicamente emersa (imersa em Syrrhopodon cryptocarpos), ereta, peristômio simples, de 16 dentes, ou ausente. Caliptra alcançando até a base da cápsula, cuculiforme (Syrrhopodon) ou campaniforme (Calymperes), caduca ou persistente.

É uma família essencialmente tropical e com uma grande diversidade na Amazônia, repre. sentada na área do guia pelos gêneros Calymperes e Syrrhopodon.

São plantas que crescem em sua maior parte nos troncos e galhos das árvores mas algumas espécies ocorrem nas rochas e no solo.

\section{Chave geral}

1. Filídios bordeados total ou parcialmente por células alongadas e hialinas ...... Chave a

$1^{\prime}$. Filícios com uma borda concolor, plana ou espessada ou alada $\ldots \ldots \ldots \ldots \ldots \ldots \ldots 2$

2. Células da lâmina superior em sua maior parte alongadas transversalmente, $1: 2$ (comprimento/largura), filidios estreitamente ovóide-lineares, até $16 \mathrm{~mm}$ de comprimento ........

\section{Calymperes lonchophyllum Schwaegr.}

2'. Células da lâmina superior quadráticas ou arredondadas, às vezes, brevemente alongadias mas nunca em sentido transversal; filídios ovóide-lanceolados até ovóide-ligulados, não mais de

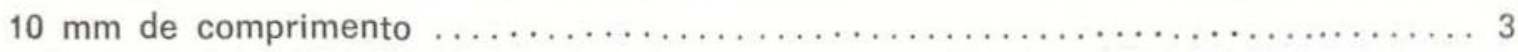

3. Margens dos filídios planos, nem espessadas nem aladas $\ldots \ldots \ldots \ldots \ldots \ldots \ldots . \ldots$

4. Filídios ligulados, ápice obtuso até entalhado, células da lâmina superior pluripapilosas

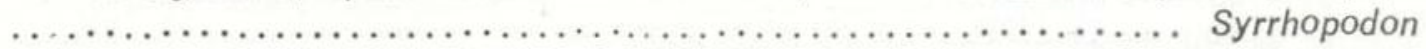
ligulatus Mont

4'. Filídios ovóide-ligulados até ovado-lanceolados (em plantas estéreis, às vezes, largamente triangulares), células da lâmina superior lisas até mamilosas ou papilosas ....

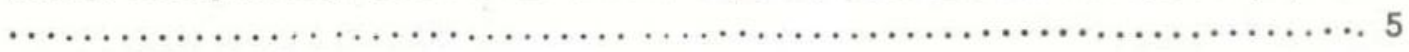


5. Cancelinas não excedendo $1 / 5$ do comprimento total do filidio normal, redendas $e$ obtusas acima, a margem do filídio delgadamente crenífera ...... Calymperes

rubiginosum

(Mitt.) Reese

5'. Cancelinas ocupando $1 / 4-1 / 3$ do comprimento total do filídio normal, redondas e obtusas acima, a margem do filídio inteira ou delgada e remotamente deníiculada

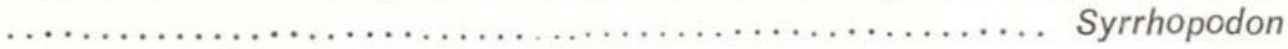

parasiticus

(Brid.) Besch.

var. parasiticus

3'. Margens dos filídios espessadas ou aladas $\ldots \ldots \ldots \ldots \ldots \ldots \ldots \ldots \ldots \ldots \ldots \ldots \ldots \ldots$

6. Teniolas presentes (marginais ou intramarginais) ............... Chave b

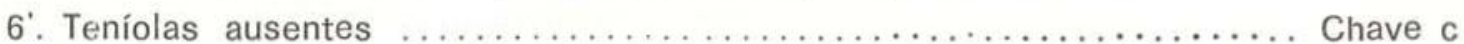

Chave A

\section{Calymperaceae com Filídios Bordeados por Células Alongadas e Hialinas}

1. A borda do filídio restringido à metade inferior da lâmina ou ao menos não aicançando

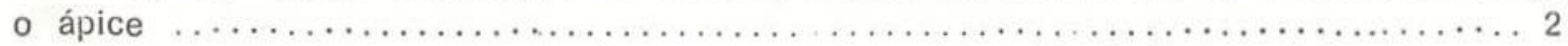

2. Ápice do filídio largamente redond́o até entalhado, a borda hialina, às vezes, ausente em: alguns filídios Syrrhopodon

ligulatus Mitt.

2'. Ápice do filídio agudo ou com menos frequêencia subobtuso, a borda hialina presente em todos os filídios

Syrrhopodon

parasiticus

(Brid.) Besch.

var. parasiticus

1. A borda do filídio estendendo-se até o ápice do filidıo ou perto dele $\ldots \ldots \ldots \ldots \ldots . .3$

3. Filídios quando secos forte e helicoidalmente torcidos, células na parte superior da lâmina laxas, quadráticas, 20-40 $\mu \mathrm{m}$ de ciâmetro

Syrrhopodon

helicophyllus

Mitt.

3'. Filídios quando secos variáveis - crispados, flexuosos, incurvados ou patentes mas nunca torcidos em hélices, células na parte superior da lâmina densas, quadráticas ou redondas, me-

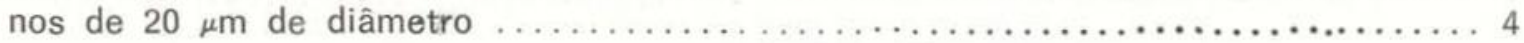

4. Margens da lâmina ao menos em alguns filídios espinhosos ou franjadas na região cio om-

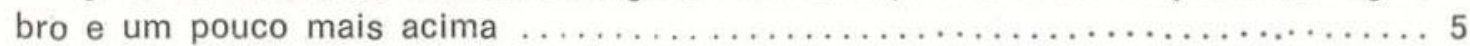

5. Plantas em coxins compactos, talos folhosos até $5 \mathrm{~mm}$ de altura, filídios crispados quando secos, 1-1,5 $\mathrm{mm}$ de comprimento, obovados até estreitamente espatulados ...

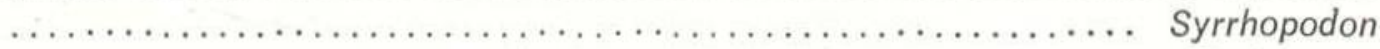
fimbriatus Mitt.

5. Planos maiores de $5 \mathrm{~mm}$ de altura, filídios quando secos curvados, flexuosos, torcidos, retos e/ou eretos, 3-6 $\mathrm{mm}$ de comprimento, ovado-lanceolados, ápice agudo até

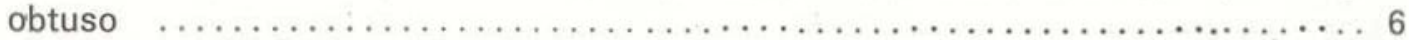

6. Filídios 3-3,5 mm de comprimento, a lâmina superior ligulada, as células na parte 
superior da lâmina pluripapilosas, a margem essencialmente inteira acima, ma: na região dos ombros franjada, ápice do filídio \pm serreado ... Syrrhopodon

brevisetus Florsch.

6'. Filídios até $6 \mathrm{~mm}$ de comprimentc, a lâminá superior lanceolada ou acuminada, as células superiores uni- ou pluripapilosas, margens freqüentemente denteadas. 7

7. Células da parte superior da lâmina delgadamente pluripapilosas pelo lado dorsal, margem da lâmina superior usual e conspícuamente franjado-dentada .. ......................................... Syrrhojodon

sylvaticus Mitt.

7'. Células da parte superior da lâmina agudamente unipapilosas pelo lado dorsal, margem superior inconspícuamente denteada, salvo perto do ápice ...........

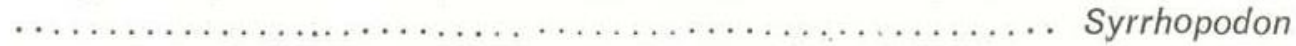

leprieurii Mont.

4: Margens da lâmina inteiras até denticuladas, nunca espinhosas ou franjadas . . . 8

8. Margem inteira, células da lâmina superiơ inchado-mamilosas pelo lado dorsal ....

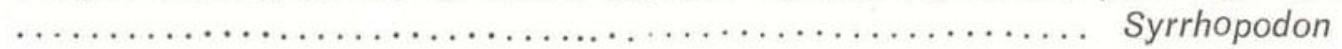

annotinus Reese

et Griffin

8. Margem irregularmente denticulada, células da lâmina superior delgada mas distintamente pluripapilosas

Syrrhopodon

parasiticus

(Brid.) Besch.

var. disciformis

(C. Muell.) Florsch

\section{Chave B}

\section{Calymperaceae com Teníolas Marginais ou Intramarginais}

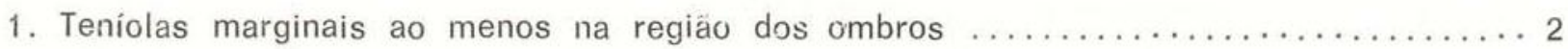

2. A lâmina superior plana ou encanada quando úmida, não involuta, margens planas... 3

3. Células superiores papilosas pelo lado dorsal, margens lisas ou delgadamente serreaum

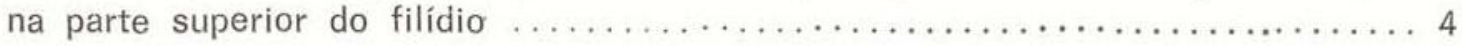

4. Células fortemente papilosas dorsalmente, até $16 \mu \mathrm{m}$ no diâmetro mais comprido, margens na metade superior da lâmina finamente serreadas, cancelinas ocupando $1 / 2$ ac comprimento total da lâmina inferior ..................... Calymperes

platyloma Mitt.

4'. Células finamente papilosas pelo lado dorsal na região do ápice e nas margens supe. riores da lâmina, até $12 \mu \mathrm{m}$ no diâmetro mais comprido, margens inteiras na metade superior da lâmina, cancelinas ocupando $5 / 8$ até $7 / 8$ do comprimento total da lâminá

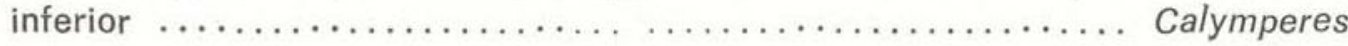

mitrafugax Florsch.

3'. Células da lâmina superior lisas ou levemente mamilosas pelo lado dorsal, margens na parte superior do filídio ásperas e duplamente serreadas ........ Calymperes

lanceolatum Hampe

2'. A lâmina superior $e$ as margens fortemente involutas quando úmidas

Calymperes

bartramii Reese 
1'. Teniolas intramarginais (as espécies desta parte da chave têm todas teníolas intramarginais

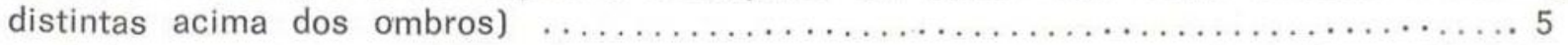

5. A lâmina superior usualmente mais larga do que a inferior, cancelinas formando acima ângulos largos com a costa, células ciorofiladias lisas até debilmente inchado-mamilosas ....

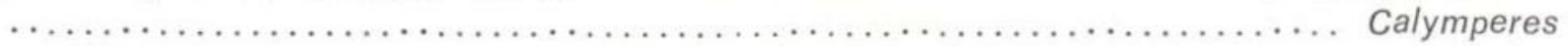
richardii

C. Niuell

5'. A lâmina superior usualmente mais estreita do que a inferior, cancelinas formando acima ângulos agudos com a costa, células clorofiladas papilosas até altamente mamilosas. . 6

6. Cancelinas fortemente mamilosas na $r \in$ gião dos ombros pelo lado dorsal, teníolas na região dos ombros afastadas da margem por 4-8 filas de células curtas.. Calymperes

erosum C. Muell.

6'. Cancelinas lisas na região dos ombros pelo lado dorsal, teníolas na região dos ombros afastadas da margem por $8-12$ filas de células curtas ........... Calymperes

donnellii Aust.

\section{Chave C}

\section{Calymperaceae sem Teníolas e com as Margens dos Filidios Espessados ou Alados}

1. A parte basal do filídio hialina ou algum tanto verde, mas, não pigmentada de cor amarela, alaran-

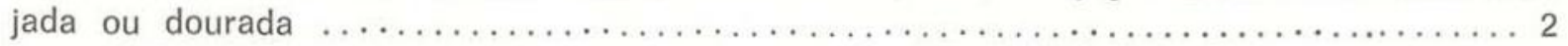

2. Filídios sem ombros ou com ombros muito débeis, acima as margens com 3 ou mais filas de dentes, cápsula imersa entre os filídios ...................... Syrrhopodon

cryptocarpos

Dozy et Molk.

2'. Filidios com ombros bem desenvolvidios e alargados, acima as margens duplamente serreadas, cápsulas exertas além das folhas ................... Syrrhopodon

incompletus Schwaegn.

$1^{\prime}$. A parte basal do filídio pigmentada de cor amarela, alaranjada ou dourada ......... 3

3. Filídios largamente ligulados, ápıce largo, apiculado, as margens superiores subinteiras até delgadas e remotamente denticuladás, sem filídios propaguliferos .... Syrrhopodon

xanthophyllus Mitt.

3. Filídios lanceolados ou oblanceolados, ápice largamente agudo até agudo ou acuminado, as margens superiores distintamente serreadas, filidios propaguliferos freqüentes ...4 4

4. Cancelinas estendendo-se até os ombros ou perto dele usualmente intactas e persistentes Syrrhopodon rigidus Hook. et Grev.

$4^{2}$. Cancelinas acabando muito abaixo dos ombros, usualmente destruidas e efêmeras.... 5

5. Margens da lâmina inferior inteiras ou \pm irregularmente serreadas, os dentes nem patentes nem recurvados, costa dos filídios normais usualmente com 2 até vários dentes conspícuos perto do ápice e pelo lado dorsal na região do ápice, cancelinas alcançando $1 / 3-1 / 2$ do comprimento da lâmina inferior ............. Syrhopodon

circinatus (Brid.) Mitt.

5'. Margens da lâmina inferior (ao menos em alguns filídios) usualmente \pm regularmen te dentadas ou serreadas com ao menos alguns dentes patentes ou recurvados, costa 
dos filídios normais usualmente lisa ou ocasionalmente com 1-2 (-3) dentes baixos acima e pelo lado dorsal perto do ápice, cancelinas muito curtas, restringidas à baso da lâmina inferior

\section{ORTHOTRICHACEAE}

Plantas pequenas até robustas, usualmente verde-escuras, freqüentemente rufescentes Talos retos ou rasteiros, com ramos secundários ascendentes até pêndulos, densamente folhosos. Filídios imbricados, retos ou com freqüência espiralado-torcidos ou crispantes quando secos, ocasionalmente em filas distintas, lanceolado-iigados, freqüentemente carenados. Costa forte, percurrente até excurrente. Células superiores redondas, mamilosas ou papilosas, as inferiores mais alongadas com ou sem uma borda distinta na parte basal do filídic, as regiões alares não diferençadas. Cápsula emersa ou imersa, pregueada ou lisa. Peristômio simples, duplo ou ausente, dentes do exóstoma muitas vezes unidos em $\delta$ ou 16 pares, endóstoma freqüentemente reduzido a uma membrana. Caliptra cuculiforme, campanulada ou mitriforme, usualmente pilosa.

É uma família amplamente distribuída, mas com maior diversidade nos trópicos. Os membros locais pertencem aos gêneros Groutiella (filídios com borda distinta na base) e Macromitrium (filídios sem borda distinta). São heliófitos que crescem sobre árvores.

\section{Pottificeae}

Plantas pequenas até moderadamente robustas, em tufos ou espalhadas. Talos simples ou parcamente ramificados. Filídios largamente ovados até obovados ou lanceolados, freqüentemente encolhidos ou torcidos quando secos. Costa forte, alcançando até perto do ápice, às vezes excurrente. Células superiores pequenas, quadráticas ou redondas, densas, comumente inchadas ou papilcsas, mais laxas e alongadas para a base do filídic. Cápsulas emersas ou, às vezes, imersas. ovóides até cilíndricas, retas. Peristômio simpies, de 16 denites, retos ou torcidos, ascendendo de uma membrana \pm alta; numas espécies os dentes são atrofiados até ausentes, opérculo tipicamente rostrado. Caliptra cuculiforme.

É uma família cosmopolita que inclui muitos pioneiros que habitam solos perturbados ou paredes e rochas. São plantas em sua maior parte de sítios abertos, soalheiros.

Os gêneros Barbula e Hyophila são os representantes locais desta família.

\section{BRYACEAE}

Plantas pequenas até robustas. Taios reios, simples ou ramificados por inovações. Filídios freqüentemente menores nas partes velhas dos talos e maiores e mais cheias nos ápices dos talos, lanceolados até ovados ou obovados, muitas vezes limbados por células mais alongádas e \pm hialinas. Costa forte, subpercurrente até longo-excurrente. Células laxas, lisas, lineares até romboidais. Cápsulas eretas, inclinadas ou pêndulas, usualmente com um colo distinto. Peristômio duplo, os 16 dentes de cada série em raios alternados, o endóstoma freqüentemente com franjas bem desenvolvidas, opérculo convexo-apiculado. Caliptra cuculiforme, pequena e caduca.

É uma família cosmopolita que oferece muitos problemas taxonômicos. Amostras sem cápsulas podem resistir à determinação.

O gênero Bryum é o representante local. Ocorre tipicamente sobre solos inorgânicos e em sitios \pm soalheiros.

\section{Bryum (2)}

1. Costa longo-excurrente, células na parte superior do filídio 3-4 X (comprimento/largura), colo da cápsula curto e truncado $\ldots \ldots \ldots \ldots \ldots \ldots \ldots \ldots \ldots \ldots \ldots \ldots \ldots \ldots$ Bryum coronatum

Schwaegr.

\footnotetext{
(2) - Chave adaptada de Forschütz (1964).
} 
1. Costa percurrente até curto-excurrente, células na parte superior do filídio 6-10 X (comprimento/ largura), colo da cápsula alongado e acuminado ................. Bryum cruegeri Hampe

ex C. Muell.

\section{PHYLlODREPANIACEAe}

(DREPANOPHYLLACEAE)

Plantas pequenas até medianas, em tufos mais ou menos laxos, simples ou escassamente ramificadas. Filídios dísticos, complanados, em filas distintas, assimétricos, mais ou menos falcados. Costa forte, percurrente. Células lisas ou papilosas, romboidais até subquadráticas, mais alongadas para a base do filídio, propágulos freqüentes. Cápsula emersa, ereta. Peristômio simples, dentes curtos, lanceolados, papilosos.

É uma família inteiramente tropicál, cujos dois gêneros ocorrem na área local.

Mniomalia cresce em tufos densos sobre paus podres e na base dos troncos vivos das florestas úmidas e sombreadas.

Phyllodrepanium (Drepanophyllum) encontra-se geralmente em troncos finos e vivos da flo. resta de terra firme. Os taios folhosos saem do substrato em um ângulo reto. É comum que os talos levem grupos de propágulos no ápice do talo.

\section{BARTRAMIACEAE}

Plantas pequenas até bem robustas, em tapetes ou coxins densos, freqüentemente glaucas (no membro local), simples até abundantemente ramificadas, tomentosas abaixo ou por quase todo o comprimento do talo. Filídios geralmente ovóide-lanceolados, subulados, as margens serrea. dos com dentes simples ou emparelhados. Costa forte, subpercurrente até longo-excurrente. Células estreitamente retanguiares, geralmente papilosas, as papilas saindo da parte apical da célula. Cápsulas imersas ou emersas, globosas, plicadas ou iisas, boca freqüentemente oblíqua, opérculo plano até convexo. Peristômio duplo ou ausente, dentes 16, endóstoma muitas vezes atrofiado. Caliptra cuculiforme, decidua.

É uma família amplamente distribuída e de grande diversidade nos trópicos. O gênero Philonotis representa a família na área do guia.

São plantas de solos molhados, inorgânicos e alcalinos, usualmente onde há bastante insolação.

\section{LEUCODONTACEAE}

Plantas medianas até robustas, em tufos amareleritos até pardacento-verdes. Talos primários rasteiros, os secundários ascendentes ou pêndulos e densamente follhosos, ramos freqüentemente vermiculados, ramos flageliformes não raros. Filídios densamente imbricados quando secos, patentes quando úmidos, ovóide-lanceolados, breve-agudos, \pm decorrentes, sem bordas distintas. Costa forte, simples ou dupla, raramente ausente, alcançando para lá da meia-lâmina ou percurrente. Células espessadas, lisas ou papilosas, as da lâmina superior romboidais, as da parte inferior do filídio mais alongadas e, às vezes, porosas, as regiões alares compostas de muitas filas de células quadráticas. Cápsulas ovóides até ovado-cilíndricas, usualmente emersa e lisas, opérculo obliquamente cônico-rostrado. Peristômio duplo, dentes 16, endóstoma freqüentemente pouco desenvolvida. Caliptra cuculiforme, usualmente desnuda.

É uma família de ampla distribuição, representada na área do guia pelo gênero Leucodontopsis. Este musgo encontra-se nas campinas e nos igapós, onde cresce sobre troncos e galhos secos. 


\section{PTEROBRYACEAE}

Plantas medianas ou robustas, comumente lustrosas, dendróides ou frondosas, os talos primários sendo rasteiros, os secundários eretos ou pêndulos, de uma base estipitada, densamente folhosos e abundantemente ramificados. Cs filídios dos ramos, às vezes, em filas distintas, filídios densos, largamente côncavos (colheriformies), ovóide-lanceolados, acuminados. Costa delgada ou forte, percurrente ou curta e bifurcada ou ausente. Células alongadas, finamente papilosas ou lisas, às vezes porosas, freqüentemente diferençadas nas regiões alares. Cápsulas ovóides, imersas ou brevi-emersas, opérculo cônico até brevirrostrado. Peristômio simples ou duplo (endóstoma gera). mente atrofiado), dentes 16 ou 32, reqüentemente emparelhados. Caliptra cuculiforme ou mitriforme.

É uma familia em sua maior parte tropical de musgos cortícolos. Pireella é o representante local.

São plantas das caatingas (perto do Rio Lages) e dos igapós onde cresce sobre troncos secos, geralmente estéreis.

Jaegerina (talos simples, filídios patentes quando secos) é outro gênero que se conhece em Mato Grosso e pode ocorrer na área do guia. No sudeste do país ocorre o gênero Pterobryon.

\section{Miteoriaceae}

Plantas geralmente robustas. Talos primários rasteiros, os secundários alongados, pêndulos, irregularmente ramificados. Filídios ovado-lanceolados, acuminados, não encolhidos quando secos. Costa simples, delgada ou moderadamente forte, sub-percurrente ou curta e bifurcada ou ausente. Células alongadas, lisas ou papilosas, as regiões alares diferençadas ou não. Cảpsula ovóide, emersa numa seta curta, opérculo cônico, brevirrostrado. Peristômio duplo, 16 dentes do exóstoma. Caliptra mitriforme ou cuculiforme, freqüentemente pilosa.

É uma familia tropical de musgos pêndulos, formando muitas vezes tapetes grandes sobre árvores ou rochas ou, em alguns casos, sobre folhas das plantas vasculares. Meteoriopsis é o representante local.

São plantas de campinas e de outras florestas \pm abertas.

\section{NECKERACEAE}

Plantas medianas até robustas, \pm lustrosas, os talos primários sendo rasteiros, os secundários ascendentes ou pêndulos, ramificaçăo pinalada ou irregular. Filídios dispostos aparentemente em filas, achatados, freqüentemente ondulados, ápice agudo ou trincado. Costa delgada, simpies, terminando um pouco para lá da meia-lâmina e mais perto da margem inferior do filídio, ou curta e bifurcada ou ausente. Células lisas, as superiores romboidais, as inferiores alongadas. Filidios periqueciais distintos dos filídios vegetativos. Cápsula imersa ou emersa numa seta curta. Opérculo curto-rostrado. Peristômio duplo, usua!mente bem desenvolvido, exóstoma de segmentos estreitamente lanceclado-subulados, endóstoma de segmentos lineares. Caliptra cuculiforme, freqüentemente pilosa.

É uma familia amplamente distribuída mas com mais diversidade nos trópicos. Neckeropsis é o representante na área do guia.

São plantas tipicamente cortícolas mas às vezes encontram-se sobre rochas.

\section{Neckeropsis}

1. Filídios essencialmente planos quando úmidos Neckeropsis disticha

(Hedw.) Kindb. 


\section{Pilotrichaceae}

Plantas delgadas até moderadamente robusta. Talos primários rasteiros, os secundários eretos ou pêndulos, frondosos, estipitados, bi- ou tripinalados, córtex de células com paredes espessacias. Filídios ovadios, côncavos, às vezes, rugosos. Costa dupla, forte, alcançando para lá da meia-lâmina e terminando freqüentemente num espinho pelo lado dorsal. Células oblongas, lisas ou papilosas. Cápsula emersa, ereta, seta curta, geralmente lisa. Opérculo cônico, brevirrostrado. Peristômio duplo, bem desenvolvido, de 16 dentes. Caliptra cônica até campanulada, cobrindo a metade ou menos da urna, pilosa.

É uma família monotípica e tropical. Pilotrichum evanescens é uma das briótas mais vistosas da área formando tufos de frondes amarelas ou rufescentes que saem verticalmente dos troncos das árvores. Ocorre numa diversidade de floresta.

Outra espécie, não colhida por nós, mas também conhecida da área é a $P$. bipinnatum.

\section{Pilotrichum}

1. Filidios dos ramos claramente rugosos; inflorescência dióica ......... Pilotrichum evanescens

(C. Muell.) Crosby

1'. Filídios dos ramos \pm lisos (um pouco ondulados perto da base); inflorescência sinóica ...... Pilotrichum bipinnatum (Schwaegr.) Brid.

\section{HOOKERIACEAE}

Plantas pequenas até robustas. Talos ramificados, muitas vezes achatados, córtex de células com paredes delgadas ou \pm espessadas. Filídios de várias formas, monodimórficas ou dimórficas numa só planta Costa forte ou débil, simples, dupla ou ausente. Células variáveis, lisas ou papilosas, as células alares não diferençadas. Se a alongada, lisa ou papilosa (às vezes altamente tuberculada). Cápsulas geralmente inclinadas ou horizontais. Opérculo rostrado. Peristômio duplo, os segmentos do endóstoma estriados com um encaixe mediano, os do endóstoma pálidos de. igual comprimento que os do exóstoma usualmente sem franjas. Caliptra cônico-mitriforme, lobu. lada su franjada na base.

É uma família principalmente tropical. Temos colhido na área do guia representantes dos gêneros Callicostella, Crossomitrium e Hookeriopsis.

Os membros desta família freqüentam uma ampla diversidade de habitats. Espécies de Callicostella parecem preferir troncos caídos e pcdres ou solos úmidos e sombreados, enquanto as de Crossomitrium são epifilas ou crescem sobre galhos finos. Espécies de Hookeriopsis habitam em geral sítios semelhantes aos de Callicostella embora uma das espécies mais vistosas que ocorre na área, a Hookeriopsis parkeriana, seja epifila.

\section{LEUCOMIACEAE}

Plantas pequenas até medianas, de textura suave e delicada. Talos rasteiros, ramifi cados irregularmente, \pm achatados. Filídios usualmente patentes, de várias formas embora tipicamente ovado-lanceolados, \pm assimétricos. Costa ausente ou bifurcada e restringida à base do filídio. Células laxas, romboidais, lisas, paredes delgadas, as regiões alares não diferençadas. Seta 
alongada, um pouco escabrosa acima. Cápsula horizontal até inclinada. Opérculo longirrostrado. Peristômio duplo, segmentos do exóstoma lanceolados, às vezes, rubros para os ápices, o endóstoma amarelo, pálido, sem franjas. Caliptra cuculiforme, parcamente pilosa.

É uma família monotípica, pequena, tropical. Compartilha muitos caracteres com as Hookeriaceae sendo uma das diferenças mais óbvias a forma da caliptra. Leucomium, o representante local, ocorre em florestas úmidas e sombreadas sobre troncos caídos e podres ou sobre tocos ou húmus.

\section{THUIDIACEAE}

Plantas delgadas até robustas, não lustrosas, crescendo em tapetes laxos, rasteiras ou \pm ascendentes, ramificação irregular ou uni-, bi- ou tripinalada, parafilias usualmente abundantes. Filídios dimórficos, os dos talos principais maiores e usualmente mais fortemente acumina:tos do que os dos ramos. Costa simples, forte, translúcida, raramente ausente. Células pequenas, \pm arredondadas ou romboidais, usualmente papilosas. Filidios periqueciais distintos dos vegetativos. Seta alongada, lisa ou papilosa. Cápsula ereta ou inclinada e moderadamente arcada. Opérculo cônico ou rostrado. Peristômio duplo, bem desenvolvido. Caliptra cuculiforme, usualmente desnuda.

É uma família quase cosmopolita e representada na área local pelo gênero Thuidium.

São plantas das florestas \pm sombreadas, ocorrendo sobre solos, troncos caídos, podres ou na base de árvores vivas.

\section{Thuidium}

1. Ramificação pinalada, filídios quando secos fortemente catenulados, filídios periqueciais não franjados.

\section{Thuidium}

involvens (Hedw.)

Mitt.

1'. Ramificação bipinalada, filídios quando secos só moderadamente catenulados, filídios periqueciais franjados nas margens $\ldots \ldots \ldots \ldots \ldots \ldots \ldots \ldots \ldots \ldots$ Thuidium

schistocalyx

(C. Muell.) Mitt.

\section{PlagiotheCiACEAE}

Plantas delgadas até robustas, tipicamente lustrosas. Talos rasteiros, irregularmente ramificados e complanados (achatados). Filídios freqüentemente assimétricos, usualmente acuminados. Costa restringida à base do filício, bifurcada, ou simples, forte e alcançando além da meialâmina. Células lineares ou ocasionalmente romboidais, lisas ou, mais raramente, papilosas, as alares diferençadas ou não. Cápsula ereta ou inclinada. Seta alongada, lisa. Peristômio duplo, bem desenvolvido, exóstoma de 16 dentes, opérculo cônico até rostrado. Caliptra cuculiforme, desnuda.

É uma família amplamente distribuída e representada na área do guia pelos gêneros /sopterygium, Pilosium e Stereophyllum.

Isopterygium cresce sobre uma diversidade de substratos e numa variedade de ambientes sempre que haja suficiente umidade.

Pilosium e Stereophyllum ocorrem em sua maior parte sobre paus podres, sobre húmus ou na base de troncos de florestas sombreadas.

\section{Isopterygium}

1. Plantas monóicas (usualmente com esporófitos), filidios ovado-lanceolados.. Isopterygıum tenerum (Sw.) Mitt. 
1'. Plantas dióicas (usualmente estéreis), filídios oblongo-ovados e com o ápice parcamente subulado Isopterygium aurantiacum

(C. Muell.) Broth.

\section{SEMATOPHYLLACEAE}

Plantas delgadas até robustas, freqüentemente lustrosas. Talos prostrados até ascendentes, irregularmente ramificados ou pinalados, homômalos ou secundiformes. Filídios tipicamente ovado-acuminados. Costa ausente ou bifurcada e restringida à base do filídio. Células oblongas até lineares, lisas ou papilosas, as das regiões alares distintas, freqüentemente infladas e pigmenta. das. Cápsula geralmente pequena e inclinada, \pm arcada. Opérculo usualmente longirrostrado. Seta alongada, lisa (mais raramente mamilosa). Peristômio simples ou duplo, endóstoma com cílios. Caliptra cuculiforme, desnuda.

É uma família essencialmente tropical e subtropicai Os gêneros locais são: Acroporium Meiothecium, Pterogonidium, Sematophyllum, Taxithelium e Trichosteleum.

Os membros desta família ocorrem em uma grande diversidade de ambientes, mas na área local alcançam a sua maior freqüência dentro das florestas abertas como nas campinas. Crescem sobre árvores, tipicamente.

\section{Sematophyllum}

1. Plantas subpinaladas, ramos horizontais; células muito alongadas, 10:1 ou mais

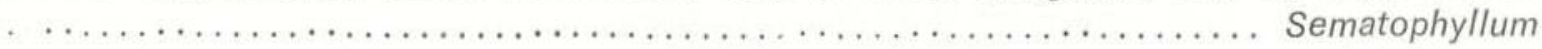
subsimplex (Hedw.) Mitt.

1'. Plantas irregularmente ramificadas, ramos ascendentes; células ovado-romboidais, até $6: 1 \ldots$

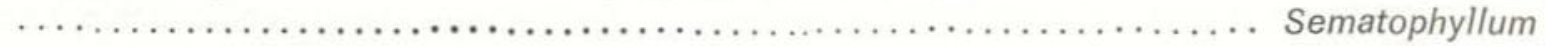
caespitosum (Hedw)

Trichosteleum

Mitt.

1. Filídios ovado-lanceolados, ápice agudo até \pm obtuso

Trichosteleum

fluviale (Mitt.) Jaeg.

1'. Filíaios ovados, mas com o acúmen subtamente estreito e torcido, ápice alongacio ............

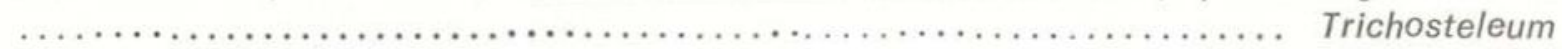
guianae (C. Muell.) Broth.

\section{HYPNACEAE}

Plantas delgadas até robustas, freqüentemente lustrosas, em tapetes \pm extensos. Talos prostrados ou ascendentes, pinalados ou subpinalados. Filídios ovados ou ovóide-lanceolados e acuminados, muitas vezes falcado-secundiformes. Costa ausente ou bifurcada e restringida à base do filídio. Células alongadas, usualmente lisas, as regiões alares freqüentemente diferenciadas mas nunca pigmentadas. Cápsula pequena até grande, usualmente inclinada e assimétrica. Opérculo cônico ou brevirrostrado. Seta alongada, lisa. Peristômio duplo, endóstoma com cílios. Caliptra cuculiforme, desnuda.

É uma família quase cosmopolita de musgos de florestas. Os gêneros locais são; Rhaco. pilopsis e Vesicularia.

São plantas de lugares úmidos e sombreados, crescendo sobre humus, paus podres ou na base de troncos vivos. 


\section{HEPATICAE E ANTHOCEROTAE}

\section{LEPIDOZIACEAE}

Plantas pequenas até bem robustas, usualmente laxas, não extensivamente adnatas ao substrato, esbranquiçadas ou verdes até amarelo-pardas, pinaladas ou pseudodicótomas, tipicamente foihosas ou mais raramente talosas (Pteropsiella); rizóides freqüentes ou raros sempre inseridos na base dos anfigástrios. Filídios e anfigástrios parecidos (Lepidozia, Microlepidozia) ou anfigástrios menores do que os filídios e distintos (Bazzania, Micropterygium) ou anfigástrios bem reduzidos (Arachniopsis, Zoopsis). Filídios tipicamente incubos, raramente inseridos transversaimente até ti súcubos, usualmente com muitos lobos ou segmentos, margens normalmente inteiras. Células de pareáes debilmente espessadas, ocasionalmente com trigonos conspícuos, cutícula lisa até papilosa, óleo-corpos geralmente vários por célula, homogêneos. Gêmulas ausentes, plantas, às vezes, com tilídios caducos. Periantos grandes, cilíndiricos na parte basal mas constrigidos e trigonos acima. Cápsula ovóide até ovóide-cilíndrica, abrindo por 4 válvulas .

É uma familia quase cosmopolita com maior diversidade nas latitudes altas do Hemisfério Austral e nas regiões montanhosas dos trópicos.

$\mathrm{Na}$ área do guia há 9 gêneros desta familia. São todas plantas de lugares úmidos e som. breados crescendo sobre troncos vivos e caídos e no chão.

\section{Bazzania (3)}

1. Filídios predominantemente 2-dentados 2

2. Filídios usualmente com vitas medianas conspícuas, anfigástrios tão largos como o talo, escassamente divididos ou lobulados

Bazzania gracilis

(Hampe et Gottsche) (Steph.

2'. Filídios sem vitas, anfigástrios mais largos do que o talo, tipicamente incisos ou lobulados

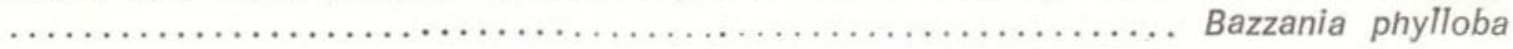

Spruce

1'. Filídios predominantemente 3-dentados 3

3. Anfigástrios com uma base auriculada, a linha de inserção distintamente recurvada... 4

4. Anfigástrios subquadráticos, alguns claramente 4-lobulados ou dentados, aurículas pequenas Bazzania teretiuscula

(Lindenb. et Gottsche) Trev.

4'. Anfigástrios redondo-quadráticos, as margens apicais onduladas, debilmente lobuladas ou dentadas, aurículas conspícuas

Bazzania robusta

Spruce

3. Anfigástrios com uma base ovada até largamente cuneada, a linha de inserção reta até

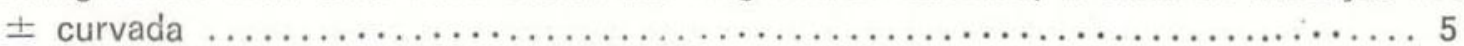

5. Anfigástrios inteiros ou escassamente 2-4 lobulados, células na parte superior do filidio $20 \mu \mathrm{m} \times 20 \mu \mathrm{m}$ Bazzania breuteliana (Lindenb. et Gottsche) Trev.

(3) - Chave adaptada e modiifcada de Fulford (1963). 
5'. Anfigástrios lobulados (os lobos variáveis), usualmente com 1 ou mais dentes incurvados na margem superior, células na parte superior do filídio $20-32 \mu \mathrm{m} \times 22 \mu \mathrm{m} \ldots$.

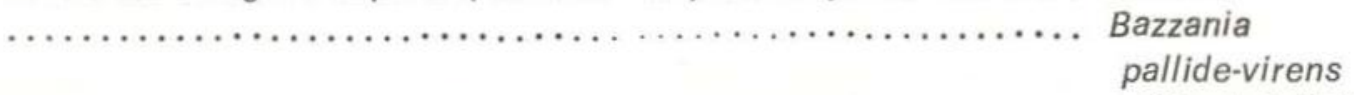

\section{Micropterygium (4)}

(Steph.) Fulford

1. Células planas até debilmente côncavas, nunca mamilosas ou papilosas $\ldots \ldots \ldots \ldots \ldots 2$

2. Filídios ovado-truncados até retangulares, só escassamente dobrados, anfigástrios não diminuindo notavelmente para o ápice do talo .................. Micropterygium leiophyllum Spruce

2'. Filídios com o ápice agudo, dobrados por toda sua extensão, anfigástrios diminuindo para o ápice do talo Micropterygium pterygophyllum

(Nees) Trev.

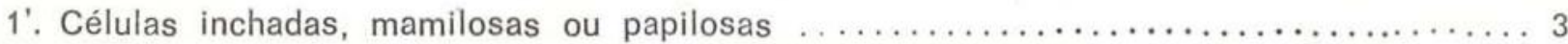

3. Filídios iongo-ovados, anfigástrios grandes, mais largos do que o talo, conspícuos .........

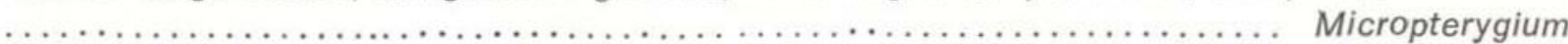
trachyphyllum Reimers

3'. Filídios lanceolados, anfigástrios \pm da mesma largura do que o talo, diminuindo para o ápice do talo

Micropterygium parvistipulum

Spruce

\section{CALyPogeitaceae}

Plantas folhosas, pequenas até medianas, verde-azuis ou, às vezes, pardas, simples ou com ramos ventrais saindo dos eixos dos anfigástrios. Filidios íncubos, ovados ou oblongos, inteiros ou debilmente bilobulados. Células um pouco grandes, paredes deígadas, trigonos pequenos ou ausentes, óleo-corpos 2-12 por célula, granulados ou segmentados. Anfigástrios menores que os filidios, e distintos, largamente ovados ou suborbiculares, tipicamente bífidos ou, numas espécies, bibíficios, com ou sem dentes suplementares. Ramos eretos, filiformes e gemíferos produzidos numas espécies. Perianto ausente mas as plantas desenvolvendo um marsúpio depois da fecundação. Cápsula longo-ovóide, abrindo por 4 válvulas.

É uma família amplamente distribuída e representada na área local por várias espécies do gênero Calypogeia.

São plantas de sítios úmidos e sombreadios, ocorrendo sobre solos humosos e inorgânicos, paus podres e, às vezes, rochas

\section{Calypogeia (5)}

1. Filídios longo-retangulares, simétricos ou quase assim 2

2. Filídios bífidos mas não profundamente, ocasionalmente inteiros, os filídios de um lado do talo freqüentemente menores do que os do outro lado .............. Calypogeia

amazonica (Spruce)

Steph.

2'. Filídios tipicamente inteiros, raramente entalhados mas só debilmente, os filídios dos dois la-

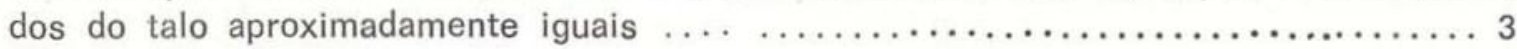

(4) - Chave adaptada de Fulford (196€)

( ${ }^{5}$ ) - Chave adaptada de Fulford (1968). 
3. Anfigástrios bífidos até além do meio, sem dentes suplementares .... Calypogeia tenax (Spruce)

Steph.

3'. Anfigástrios fendidos mas só até $1 / 3$ de seu comprimento, muitas vezes com dentes ou

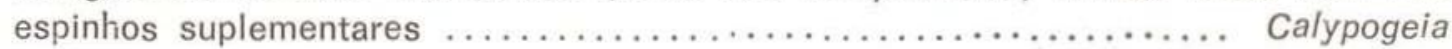

parallelogramma

(Spruce) Steph.

1'. Filídios subquadráticos até largamente ovados, assimétricos 4

4. Anfigástrios bífidos Calypogeia rhombifolia (Spruce Steph.

4'. Anfigástrios bibífidos

Calypogeia lechleri (Spruce) Steph.

\section{LOPHOCOLEACEAE}

Plantas folhosas, medianas até moderadamente robustas, verde-esbranquiçadas, simples ou com ramos ventrais saindo dos eixos dos anfigástrios. Filídios súcubos, ovados até trapezoidais, próximos até imbricados, tipicamente bilobulados, às vezes, truncados. Células laxas, parecies delgadas, trigonos pequenos ou ausentes, óleo-corpos poucos, até 8-10 por célula, compostos. Anfigástrios grandes (embora menores e distintos que os filídios), bilobulados, freqüentemente com dentes ou cílios suplementares. Gêmulas, quando produzidas, sobre as margens dos filídios. Periantos bem desenvolvidos, trigonos. Cápsula ovóide até brevicilíndrica.

É uma família amplamente distribuída, representada localmente pelo gênero Lophocolea.

São plantas de florestas úmidas e sombı eadas. Crescem sobre paus podres, húmus e so. los inorgânicos.

\section{Lophocolea (6)}

1. Margens dos filidios serreadas ou com poucas até muitas franjas, espinhos ou dentes .......

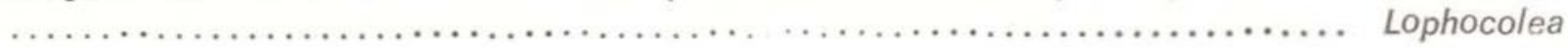

liebmanniana

Gott.

$\because$. Margens dos filídios inteiras ou com poucos dentes nas margens superiores ......... 2

2. Anfigástrios divididos $1 / 3-1 / 2$ ou mais de seu comprimento em 4 (ou raramente mais) seg.

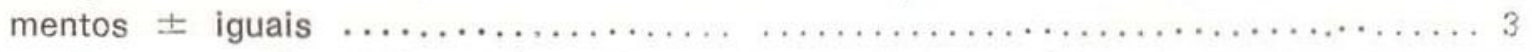

3. Segmentos dos filídios ("dentes") usualmente de 6-10 células, as margens superiores dos filídios freqüentemente com $1-2$ dentes................. Lophocolea

perissodonta (Spruce) Steph.

3'. Segmentos dos filidios ("dentes") de $2-4$ células, as margens superiores dos filidios inteiras Lophocolea martiana Nees in G., L. e N

2. Anfigástrios bífidos com um só dente suplementar de cada lado Loprocolea connata (Sw.) Nees in G., L. e N.

$\left({ }^{6}\right)$ - Chave adaptada de Fulford (1976) 


\section{Plagiochillaceae}

Plantas delgadas até bem robustas, em tapetes laxos ou misturadas com outras bridfitas. Talos simples os irregularmente ramificados. Filídios súcubos, distanciados até amplamente imbricados, de várias formas mas nunca lobulados ou profundamente incisos, margens usualmente denteadas ou franjadas. Células de paredes \pm delgadas mas normalmente com trigonos grandes. Anfigástrios inconspícuos ou ausentes. Perianto fortemente comprimido lateralmente, um pouco mais largo e truncado para o ápice. Cápsula ovóide.

É uma família essencialmente tropical mas de ampla distribuição. Plagiochila, o gênero da área local, é o maior gênero das briófitas com aproximadamente 1.600 espécies.

São plantas tipicamente cortícolas, ocorrendo numa grande diversidade de ambientes

\section{Plagiochila}

1. Filidios distanciados uns dos outros no talo, sendo exposta a superfície dorsal do talo ... 2

2. Trigonos das células inchados, filídios usualmente encolhidos quando secos, \pm deflexos ....

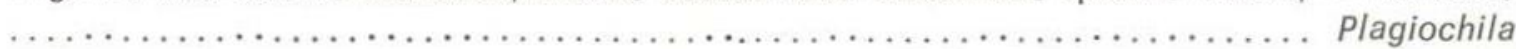

rutilans Lindbg.

2'. Trigonos das células não inchados (os lados dos trigonos não côncavos), filídios usualmente planos quando secos, não deflexos $\ldots \ldots \ldots \ldots \ldots \ldots \ldots \ldots \ldots \ldots \ldots$ Plagiochila subplana Lindbg.

1'. Filídios densamente próximos, a superfície dorsal do talo escondida ou parcamente exposta...3

3. A margem dorsal do filídio dentado-espinhosa perto da base ........ Plagiochila

3' A margem dorsal do filídio inteira hylaecoetis Spruce

Plagiochila serrata (Roth.)

Lindbg.

\section{ADELANTHACEAe}

Plantas delgadas até grandes, esbranquiçadas, verdes, amarelo-pardas ou vermelho-púrpuras, em tapetes \pm densos ou misturadas entre outras briófitas. Talos prostrados com rizóides pelo lado ventral, freqüentemente com ramos gemíferos \pm eretos. Outros ramos saem pelo lado ventral do talo. Filídios súcubos, ovados, orbiculares ou oblongo-retangulares, margens planas ou debilmente involutas e espessadas, às vezes onduladas. inteiras. Células de paredes espessadas com trigonos grandes. Óleo-corpos grandes, segmentados, 2-5 por célula. Anfigástrios pequenos, de só umas poucas células ou ausentes. Perianto alongado-ovado, arredondado abaixo, trigono aci. ma, contraído abaixo da boca. Cápsula ovóide.

É uma família amplamente distribuída, representada localmente pelos gêneros Anomoclada e Odontoschisma.

São plantas de florestas \pm abertas, freqüentemente nas campinas, crescendo sobre paus podres, solos e às vezes sobre árvores.

\section{Odontoschisma}

1. Filidios \pm planos, margens planas $\ldots \ldots \ldots \ldots \ldots \ldots \ldots \ldots \ldots \ldots \ldots$ Odontoschisma falcifolium Steph.

1'. Filidios côncavos, margens levemente involutas.................... Odontoschisma brasiliense Steph. 


\section{RADULACEAE}

Plantas pequenas até medianas, usualmente adnatas ao substrato, verde-olivas ou verdeamarelas. Ramos vegetativos infra-axilares (saindo debaixo da carena do filídio normail). Rizóides restringidos ao lado ventral dos lóbulos (um caráter peculiar a esta família). Filídios íncubos. ovados ou largamente falcados, margens planas, às vezes, recurvadas, inteiras (com gêmulas marginais numas espécies). Células freqüentemente do mesmo tamanho por todo o filídio ou variando só um pouco, paredes delgadas, trigonos pequenos até grandes ou ausentes. Óleo-corpos 1-vários por célula, grandes, granulares. Lóbulos variáveis quanto à forma e tamanho, muitas vezes, inflados. Anfigástrios ausentes. Perianto dorsiventralmente comprimido, mais largo e truncado acima. Cápsula ovóide ou oblonga.

É uma família monotípica com mais desenvolvimento nos trópicos embora de ampla distri. buição. O gênero Radula conta com centenas de espécies que em sua maioria são cortícolas mas com outras epifilas ou saxícolas.

São plantas de vários ambientes, mas com maior freqüência nas florestas úmidas.

\section{Frullaniaceae}

Plantas pequenas até bem robustas, em tapetes puros ou misturados com outras briófitas adnatas ou livres do substrato, tipicamente rufescentes, às vezes, quase pretas ou verde-olivas ramificação pinalada, os ramos menores do que os talos. Rizóides restringidos à base dos anfi. gástrios. Filídios íncubos, tipicamente côncavos, ovados até orbiculares, ápice arredondado ou agudo até acuminado, ocasionalmente subulado, margens inteiras. Células de paredes \pm engrossadas trigonos pequenos até grandes. Lóbulos distintos, livres do filídio (lobo dorsal) salvo por um "talo" bem estreito, usualmente inflados, galeiformes, às vezes, planos ou com uma parte inferior plana. Anfigástrios conspícuos, escasso até marcadamente bífidos, margens planas ou recurvadas, inteiras ou dentadas. Perianto usualmente obovado, às vezes, cilíndrico, liso ou com 3-5 carenas lisas ou tuberculadas contraídas no ápice do perianto formando um rostro.

É uma família de ampla distribuição alcançando a maior diversidade nos trópicos. O gênero principal, Frullania, contém mais de 1.000 espécies.

São plantas de sítios soalheiros, bem freqüentes nas campinas. Crescem sobre árvores. solos e rochas.

\section{Frullania}

1. Lóbulos pêndulos, a boca orientada para o ápice do talo, plantas bem robustas

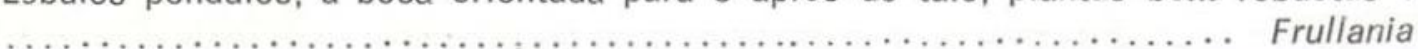

nodulosa (Reinw., Blume e Nees) Nees

1'. Lóbulos eretos, a boca orientada para a base do talo, plantas menores $\ldots \ldots \ldots \ldots \ldots 2$

2. Anfigástrios densamente imbricados, orbiculares até reniformes, entalhados, filídios subesquarrosos

Frullania

gibbosa Nees

in G., L. e N.

2'. Anfigástrios distanciados, até imbricados, obovados até ovóide-retangulares, bífidos até

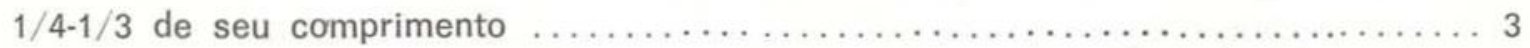

3. Anfigástrios distanciados, tão largos como o talo ou um pouco mais, margens planas. plantas bem pequenas, \pm adnatas ao substrato $\ldots \ldots \ldots \ldots \ldots \ldots$. Frullania

neesii Lindb. 
3'. Anfigástrios imbricados, obovados até oblongo-ovóides, mais largos que o talo, margens recurvadas, plantas medianas, libertas do substrato salvo na base .... Frullania

montagnei Gott.

\section{LEJEUNEACEAE}

Plantas bem pequenas até robustas, vercies ou verde-amarelas, às vezes pardas ou canelas mas quase nunca rufescentes. Ramos infra-axilares (saindo debaixo da carena do filídio normal). Rizóides em tufos restringidos aos lados ventrais dos anfigástrios ou dos talos. Filídios planos até côncavos, de várias formas, margens inteiras, crenuladas ou dentadas. Células arredondadas ou oblongas, de paredes \pm delgadas, trigonos grandes, pequenos ou ausentes. Óleo-corpos variáveis. Lóbulo largamente atado ao filídio, formando uma carena comprida e \pm paralela ao eixo longitudinal do filídio, usualmente inflado, a margem liberta inteira ou com 1-vários dentes, às vezes reduzida a uma plica pequena. Anfigástrios presentes ou ausentes, inteiros ou bífidos, com ou sem dentes laterais. Perianto cilíndrico até comprimido, com 3-5 carenas (mais raramente 10-14), lisas, papilosas ou tuberculadas, constringidas para o ápice formando um rostro tubuloso (curto ou comprido). Cápsulas globosas.

É uma familia basicamente tropicai mas com elementos nas regiões temperadas e até subpolares. São as hepáticas mais ubiquas nos trópicos de elevações baixas e medianas crescendo sobre troncos, galhos e folhas, mais raramente sobre rochas e solos.

\section{CHAVE PARA AS SUBFAMílias(?)}

1. O setor ventral do talo de 1-2 células corticais (anfigástrios, quando presentes, inseridos sobre 2 linhas de células); anfigástrios bífidos ou ausentes; periantos usualmente de 5 carenas; plantas tipicamente delicadas, verdes até verde-amarelas (mais raramente douradas ou pardas até

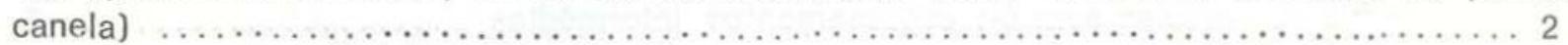

2. Anfigástrios presentes ou ausentes, quando presentes um por cada filídio ..... Paradoxae

2'. Anfígástrios sempre presentes, com metade do número de filídios ......... Schizostipae

1'. O setor ventral do talo de 4 ou mais células corticais (anfigástrios inseridos sobre 4 ou mais linhas de células $\left({ }^{8}\right)$; anfigástrios inteiros ou ligeiramente emarginados pelo lado apical; periantos usualmente de 3 carenas principais (às vezes com carenas suplementares); plantas tipica mente robustas, pardas ou fuscas até verde-escuras $\ldots \ldots \ldots \ldots \ldots \ldots \ldots \ldots$ Holostipae

\section{PARADOXAE}

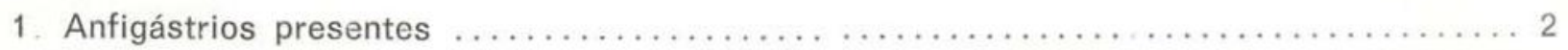

2. Filídios obovóides até espatulados, a parte distal utriculariforme $\ldots \ldots \ldots$. Colura spp.

2'. Filídios arredondados, planos ou côncavos, nunca utriculariformes .... Diplasiolejeunea spp. a. Margens dos filídios de 1-4 linhas de células hialinas, sobre folhas

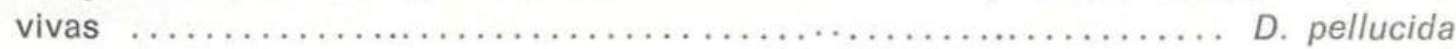

(Meissn.) Schiffn.

a'. Margens dos filídios concolores, sobre troncos e galhos ....... D. rudolphiana Steph.

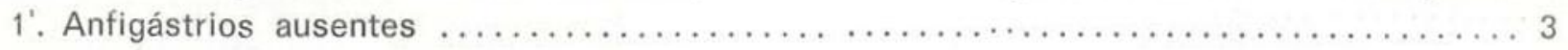

(7) - Adaptada e modificada de Schuster (1955).

$\left({ }^{8}\right.$ ) - Alguns gêneros abarcam ambas espécies de Holostipae e Schizostipae. O gênero Hygrolejeunea, por exemplo revela que por sua 1) cor, 2) número de células corticais e 3) morfologia do perianto pertence à série Schizostipae, embora a espécie local, H. reflexistipula, é curiosomenta Holostipae! 
3. Plantas delicadas até extremamente delicadas $(0,25-0,8 \mathrm{~mm}$ de largura); células do filídio e do lóbulo freqüentemente cônicas ou tuberculadas; filídios \pm variáveis; periantos inflados ou fracamente comprimidos, as carenas laterais nunca auriculadas acima $\ldots \ldots \ldots \ldots 4$

4. Plantas pequenas mas não muito frágeis; filídios não extremamente variáveis; rostro do perianto bem desenvolvido ........................ Cololejeunea spp.

4'. Plantas muito pequenas e extremamente frágeis; filídios marcadamente variáveis; rostro do perianto um vestígio ou ausente Aphanolejeunea spp

(A. sicaefolia (Gott. Evans)

3'. Plantas \pm robustas $(0,8-1,6 \mathrm{~mm}$ de largura); filídios e lóbulos usualmente lisos; periantos \pm comprimidos, obcordiformes, as carenas la terais auriculadas acima ........ Leptocolea spp.

a. Margem do filídio inteira, de células hialinas formando uma borda distinta .. L. planifolia

Evans

a. Margem apical do filídio fraca mas distintamente denticulada, sem uma borda hialina $\ldots \ldots \ldots \ldots \ldots \ldots \ldots \ldots \ldots \ldots \ldots \ldots \ldots \ldots \ldots \ldots \ldots \ldots \ldots \ldots \ldots \ldots$. scarbriflora (Gott. Evans)

HOLOSTIPAE (?)

1. Filidios quando secos suberetos (ápice do filídio, dando para o ápice do talo) e convolutos pelo talo, fortemente patentes quando úmidos, células medianas do filídio distintamente mais compridas que largas, com trigonos cordiformes (trigono com dois lados convexos e um lado côn-

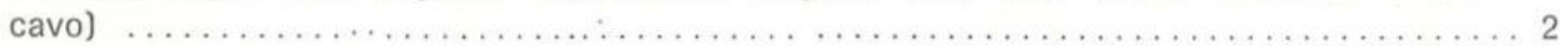

2. As paredes das células com 1-3 espessamentos intermédios (perianto com 3 plicas, sem inovaçōes), plantas sobre folhas e galhos finos............... Caudalejeunea lehmanniana

(Gott.) Steph.

2'. As paredes das células com $0-1$ espassamentos intermédios $\ldots \ldots \ldots \ldots \ldots \ldots \ldots$

3. Lóbulo do filídio com 0-1 dentes marginais, óleo-corpos segmentados, 3-8 por célula, pe-

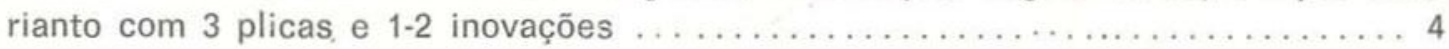

4. Plantas \pm preto-escuras sobretudo quando secas, anfigástrios aparentemente adnatos ao talo ou escassamente recurvados mas não canaliculados, margens das brácteas $\mathrm{e}$ bractéolas femininas inteiras .................... Mastigolejeunea auriculata

(Wils. et Hook.) Schiffn.

4. Plantas verde-olivas, anfigástrios fortemente patentes, canaliculados, margens das brácteas e bractéolas femininas denteadas ............ Thysananthus amazonicus

(Spruce) Steph.

3'. Lóbulo do filídio com 2-8 dentes marginais, óleo-corpos homogêneos, 10-20 por céiula, perianto com $5-10$ plicas, sem inovações ..................... Acrolejeunea spp.

$1^{\prime}$. Filídios secos ou úmidos patentes, planos ou incurvados mas não convolutos pelo taìo, células medianas do filídio \pm isodiamétricas, trigonos não cordiformes $\ldots \ldots \ldots \ldots \ldots \ldots \ldots 6$

6. Margens dos filídios e dos anfigástrios dentadas, plantas sobre folhas e galhos finos .....

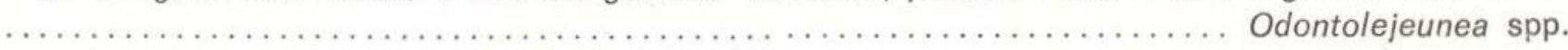

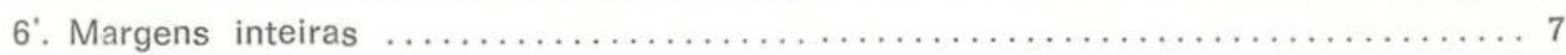

7. Filídios e anfigástrios com ocelos (os ocelos numerosos e espalhados)

Stictolejeunea squamata

(Willd.) Schiffn.

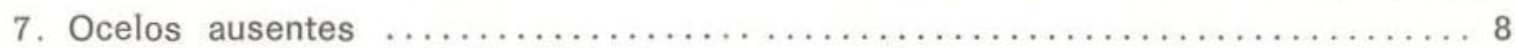

8. O setor ventral do talo (A porção de baixo da linha de inserção do anfigástrio) de só

${ }^{(9)}$ - Chave para esta Subfamilia é contribuiçăo do hepatacólogo, Dr. S. R. Gradstein 
2 células corticais (toda a largura da porção ventral do talo composto de 2 células corticais Hygrolejeunea reflexistipula

(Spruce) Steph.

8'. O setor ventral do talo de $4-12$ células corticais ................... 9

9. Plantas verdes ou pardas, não pretas, lóbulo quando bem desenvolvido distintamente mais comprido que largo, perianto com 3-5 plicas lisas ou debilmente den-

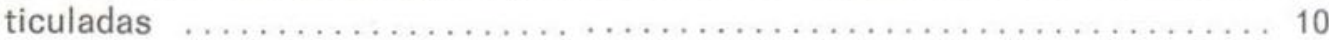

10. As paredes das células com 1-3 espessamentos intermédios, perianto sem inovações (veja núm. 3) ................... Caudalejeunea lehmanniana

(Gott.) Steph.

10'. As paredes das células com 0-1 espessamentos intermédios, inovações presen-

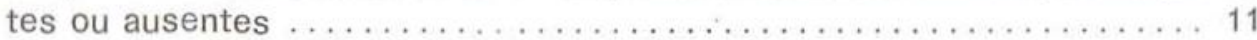

11. Perianto com 1-2 inovações, lóbulo das brácteas femininas reduzido a uma pequena plica, filídios quando úmidios não subesquarrosos. . Archilejeunea spp

11. Perianto sem inovações, lóbulo das brácteas femininas grande, quase tão comprido como a bráctea, filídios quando úmidos curvando fortemente acima chegando a estas subverticais até esquarrosos .......... Verdoornianthus griffinii Gradst.

9' Plantas verdes até pretas, sobretudo quando secas, lóbulo escassamente mais comprido que largo, freqüentemente pequeno e fortemente inflado, perianto com 2-4 plicas denteado-laciniadas . . . . . . . . . . . . . . . . . . . . . 12

12. Plantas robustas, $2-3 \mathrm{~mm}$ de largura, com anfigástrios grandes, perianto lateral num ramo curto e com uma inovação curta. Symbiezidium spp.

12. Plantas pequenas, ca. $1 \mathrm{~mm}$. de largura, perianto terminal no talo ou no ramo comprido, sem inovações ................ Lopholejeunea subfusca

(Nees) Steph

\section{Acrolejeunea}

1. Lóbulo do filídio com 2-4 dentes iguais Acrolejeunea emergens (Mitt.) Steph.

1'. Lóbulo do filídio com 5-8 dentes, o dente apical mais longo que os outros .. Acrolejeunea torulosa (L. et L)

Schiffn.

\section{SCHIZOSTIPAE}

1. Talos nus ou ao menos parcialmente pela perda de filídios caducos; células do filídio hexago-

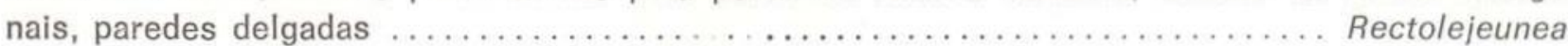

cf. maxonii Evans

1'. Talos com filídios persistentes; céluias dos filídios variáveis, usualmente com trigonos peque-

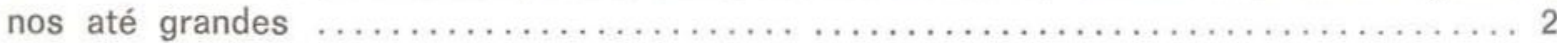

2. Os lobos dos anfigástrios amplamente divergentes, os anfigástrios mais largos no ápice

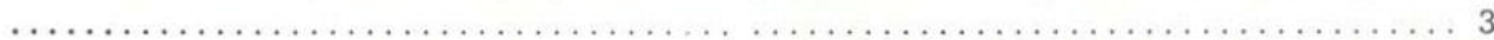

3. Lobos do anfigástrio amplos (2-3 células de largura) com o ápice obtuso ... Harpalejeunea tenuicuspis (Spruce) Steph. 
3'. Lobos do anfigástrio estreitos (1-2 células de largura) com o ápice agudo 4

4. Margem do filídio usualmente crenulada até dentada ou lobulada, ápice do filídio agu do até acuminado, freqüentemente falcadio; a área central dos anfigástrios ocupada por células semelhantes às da periferia ................ Drepanolejeunea spp. a. Filídios amplamente ovados até suborbiculares, palmadamente incisas ou lobula

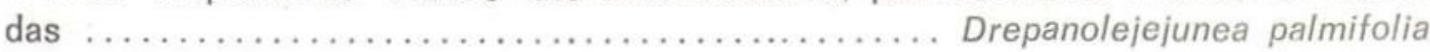

(Nees) Schiffn

a'. Filídios ovóide-alongados, acuminados com 1-2 dentes grossos ... Drepanolejeunea cf. bidens Haynes

4'. Margem do filídio inteira, ápice amplamente agudo até obtuso; a área central cio anfigástrio ocupada por células menores que as da periferia .... Leptolejeunea elliptica

(Lehm. et Lindenb.) Schiffn.

2'. Lobos do anfigástrio \pm divergentes, paralelos ou até coniventes, o anfigástrio usualmente mais largo abaixo do ápice ...................................... 5

5. Lóbulos ocupando $2 / 3$ até $3 / 4$ a área dos filídios, plantas diminutas (até $0,25 \mathrm{~mm}$ de lar-

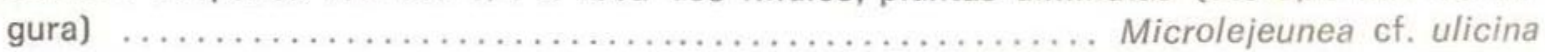

(Tayl.) Evans

5'. Lóbulos ocupando menos de $1 / 2$ a área dos filídios, plantas tipicamente maiores

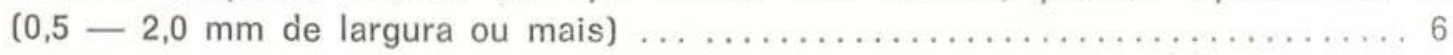

6. Filídios com ocelios ................................... 7

7. Ocelos restringidos à base do filídio, plantas lustrosas usualmente pardas até canelas; perianto com 4 cornos ........................ Ceratolejeunea spp.

$7^{\prime}$. Ocelos espalhados pelo filídio, não restringidos à base $\ldots \ldots \ldots \ldots \ldots . . .6$

8. Plantas \pm transparentes; ocelios conspícuos, castanhos, ocorrendo até sobre o perianto Pictolejeunea sprucei Grolle

8. Plantas \pm opacas quando secas; ocelos não conspícuos e não sobre o pe-

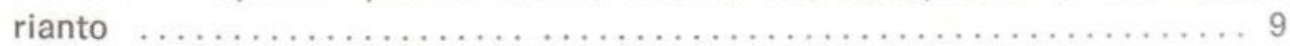

9. Lóbulos alongado-retangulares, 3-5 X (comprimento/largura); carenas do perianto lisas, não infladas, brácteas e bractéolas femininas inteiras Pycnolejeunea callosa

(Lindenb.) Steph.

9' Lóbulos ovados, 1-2 X (comprimento/largura); carenas do perianto inflados acima, brácteas e bractéolas femininas aguda e irregularmente laciniadas Kingiolejeunea ornata Robins

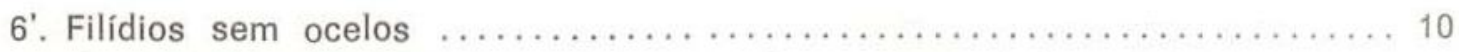

10. Anfigástrios com uma enseada ampla e arredondada, também com um par de dentes laterais conspícuos; perianto fortemente espinhoso-inciso $\ldots \ldots \ldots \ldots \ldots$.

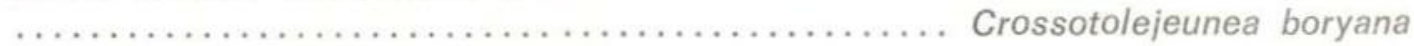

(Mont.) Schiffn.

10'. Anfigástrios com uma enseada \pm estreita, arredondada ou aguda, sem dentes laterais conspícuos; perianto liso ou espinhoso-inciso ............. 11

11. A margem do filídio agudamente crenulada: periantos fortemente obovados até piriformes, espinhoso-incisos ................. Prionolejeunea spp.

11. A margem do filídio inteira ou quase assim; periantos inteiros .... 12 
12. Óleo-corpos 1-5 por célula, grandes, segmentados, enchendo o lúmen ou

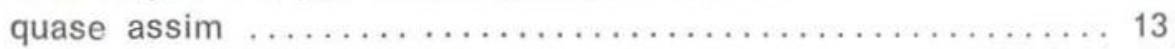

13. Filídios laxos, abobadados quando secos, plantas sobre substratos sujeitos a inundações periódicas (à margem dos rios)..Potamolejeunea polystachya (Spruce) Steph.

13'. Filídios imbricados, não conspicuamente laxos, plantas de substratos não inundados periodicamente ........... Cheilolejeunea spp.

12'. Óleo-corpos 1-7 (-20) por célula, pequenos, não enchendo o lúmen

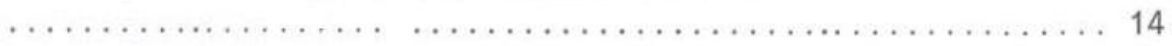

14. Plantas verdes ou verdes-amarelas, anfigástrios arredondados até parcamente cordiformes na base, $1-2,5 \mathrm{X}$ a largura do talo, trigonos usualmente não conspícuos ................... Lejeunea spp.

14'. Plantas verde-esbranquiçadas, anfigástrios tipicamente cordiformes ou auriculados na kase, $2-5 \mathrm{X}$ a largura do talo, trigonos e espessamentos intermédios conspícuos .............. Taxilejeunea spp.

\section{DILAENACEAE}

Plantas talosas, liguladas ou flabeliformes, simples ou abundantemente ramificadas. Costa conspicua. Margens do talo de um só estrato, freqüentemente onduladas, com ou sem papilas mucilaginosas, ocasionalmente dentadas mas nunca com cílios ou pêlos. Invólucro debaixo dos arquegônios pelo lado dorsal do talo, cupuliforme com uma margem franjada (Pallavicinia) ou reduzido a uma escama dentada até laciniada ou reduzido a um lobo (Symphyogyna).

É uma família de ampla distribuição tanto no Hemisfério Boreal quanto no Austral. Conhecem-se os dois gêneros, Pallavicinia e Symphyogyna, da área do guia.

São plantas encontradas tipicamente nas bordas lodosas dos igarapés ou sobre paus podres e molhados ou em chãos humosos ou argilosos.

\section{Aneuraceae}

Plantas talosas, pinaladas ou bipinaladas ou irregularmente ramificadas. Costa parcamen. te diferenciada ou aparentemente ausente. Margens do talo multiestratadas, sem pêlos e sem papilas mucilaginosas. Usualmente sem rizóides. Óleo-corpos presentes e distintos. Os órgãos sexuais nos ramos curtos laterais. Cápsuia longo-ovóide.

É uma família quase cosmopolita e representada localmente pelos gêneros Aneura e Riccar. dia.

São plantas de sítios sombreados e bem úmidos ou até molhados. Crescem sobre paus podres, rochas molhadas e nos leitos dos rios.

\section{RICCIACEAE}

Plantas talosas, cordiformes ou lineares, formando freqüentemente rosetas no solo ou flu. tuando sobre águas estagnadas. O lado ventral com rizóides e escamas, as últimas às vezes pig. mentadas. O lado dorsal normalmente convexo, cada lobo do talo com um rego mediano. Esporófito reduzido essencialmente a uma cápsula globosa e cleistocárpica, abrindo por degradação da parede. Esporos grandes, pardos, ornamentados. Sem elatérios. 
É uma família quase cosmopolita sendo o representante local o gênero Ricciocarpus. aquáticas.

São plantas estacionais, flutuando na superfície de águas quietas entre outras plantas

\section{ANTHOCEROTACEAE}

Plantas talosas, essencialmente arredondadas, com margens onduladas, crispantes ou planas, adnatas ao substrato pelos rizóides ventrais, plantas velhas freqüentemente colonizadas por cianofíceas (Nostoc). Células distintas por conter um só cloroplasto grande. Sem ólec-corpos Esporófitos longo-cilíndricos, verdes até pardos, abrindo desde o ápice para baixo por duas linhas de sutura. Esporos amarelos ou escuros. Pseudoelatérios misturados com os esporos.

É uma família de distribuição quase global, freqüentando solos úmidos e alcalinos ou mais raramente sobre árvores (Dendroceros).

Não temos colhido Anthocerotaceae nas proximidades de Manaus embora devam ocorrer lá. Anthoceros é o gênero mais conhecido. Alguns autores aceitam o nome Phaeoceros para as espécies com esporos amarelos. 


\begin{tabular}{|c|c|c|}
\hline \multicolumn{3}{|l|}{$\begin{array}{l}\text { Classe MUSCI } \\
\text { Sphagnidae }\end{array}$} \\
\hline \multicolumn{3}{|l|}{$\begin{array}{l}\text { Sphagnales } \\
\text { Sphanale }\end{array}$} \\
\hline Sphagnaceae & 1. & Sphagnum \\
\hline \multicolumn{3}{|l|}{ Bryidae } \\
\hline Fissidentales & & \\
\hline Fissidentaceae & 2. & Fissidens \\
\hline \multicolumn{3}{|l|}{ Discranales } \\
\hline Discranaceae & & $\begin{array}{l}\text { Campylopus } \\
\text { Dicranella }\end{array}$ \\
\hline Leucobryaceae & $\begin{array}{l}5 . \\
6 .\end{array}$ & $\begin{array}{l}\text { Leucobryum } \\
\text { Octoblepharum }\end{array}$ \\
\hline \multicolumn{3}{|l|}{ Syrrhopodontales } \\
\hline Calymperaceae & & $\begin{array}{l}\text { Calymperes } \\
\text { Syrrhopodon }\end{array}$ \\
\hline \multicolumn{3}{|l|}{ Pottiales } \\
\hline Pottiaceae & $\begin{array}{r}9 . \\
10 .\end{array}$ & $\begin{array}{l}\text { Barbula } \\
\text { Hyophila }\end{array}$ \\
\hline \multicolumn{3}{|l|}{ Orthotrichales } \\
\hline Orthotrichaceae & $\begin{array}{l}11 . \\
12 .\end{array}$ & $\begin{array}{l}\text { Groutiella } \\
\text { Macromitrium }\end{array}$ \\
\hline \multicolumn{3}{|l|}{ Eubryales } \\
\hline Bryaceae & 13. & Bryum \\
\hline Phyllodrepaniaceae & $\begin{array}{l}14 . \\
15 .\end{array}$ & $\begin{array}{l}\text { Mniomalia } \\
\text { Phyllodrepanium }\end{array}$ \\
\hline Sartramiaceae & 16. & Philonotis \\
\hline \multicolumn{3}{|l|}{ Isobryales } \\
\hline Leucodontaceae & 17. & Leucodontopsis \\
\hline Pterobryaceae & 18. & Pireella \\
\hline Meteoriaceae & 19. & Meteoriopsis \\
\hline Neckeraceae & 20. & Neckeropsis \\
\hline \multicolumn{3}{|l|}{ Hookeriales } \\
\hline Pilotrichaceae & 21. & Pilotrichum \\
\hline \multirow[t]{2}{*}{ Hookeriaceae } & 22. & Callicostella \\
\hline & $\begin{array}{l}23 . \\
24 .\end{array}$ & $\begin{array}{l}\text { Crossomitrium } \\
\text { Hookeriopsis }\end{array}$ \\
\hline Leucomiaceae & 25. & Leucomium \\
\hline \multicolumn{3}{|l|}{ Hypnobryales } \\
\hline Thuidiaceae & 26. & Thuidium \\
\hline Plagiotheciaceae & 27 & Isopterygium \\
\hline & $\begin{array}{l}28 . \\
29 .\end{array}$ & $\begin{array}{l}\text { Pilosium } \\
\text { Stereophyllum }\end{array}$ \\
\hline
\end{tabular}


Sematophyllaceae

Hypnaceae

\section{Classe HEPATICAE Jungermanninae Jungermanniales Lepidoziaceae}

Calypogeiaceae Lophocoleaceae Plagiochilaceae Adelanthaceae

Radulaceae Frullaniaceae Lejeuneaceae Lejeuneoidae Holostipae

Schizostipae
30. Acroporium

31. Meiothecium

32. Pterogonidium

33. Sematophyllum

34. Taxithelium

35. Trichosteleum

36. Rhacopilopsis

37. Vesicularia

38. Arachniopsis

39. Bazzania

40. Microlepidozia

41. Micropterygium

42. Mytilopsis

43. Pteropsiella

44. Regredicaulis

45. Telaranea

46. Zoopsis

47. Calypogeia

48. Lophocolea

49. Plagiochila

50. Anomoclada

51. Odontoschisma

52. Radula

53. Frullania

54. Acrolejeunea

55. Archilejeunea

56. Caudalejeunea

57. Lopholejeunea

58. Mastigolejeunea

59. Odontolejeunea

60. Stictolejeunea

61. Symbiezidium

62. Thysananthus

63. Verdoornianthus

64. Ceratolejeunea

65. Cheilolejeunea

66. Crossotolejeunea

67. Drepanolejeunea

68. Harpalejeunea

69. Hygrolejeunea

70. Kingiolejeunea

71. Lejeunea

72. Leptolejeunea

73. Microlejeunea 
74. Pictolejeunea

75. Potamolejeunea

76. Prionolejeunea

77. Pycnolejeunea

78. Rectolejeunea

79. Taxilejeunea

Paradoxae

Diplasiae

Aphylliae

Metzgeriales

Dilaenaceae

Aneuraceae

Marchantiae

Marchantiales

Ricciaceae

80. Colura

81. Diplasiolejeunea

82. Aphanolejeunea

83. Cololejeunea

84. Leptocolea

85. Pallavicinia

86. Symphyogyna

87. Aneura

88. Riccardia

89. Ricciocarpus

\section{Classe ANTHOCEROTAE}

Anthocerotales

Anthocerotaceae

90. Anthoceros 


\section{SUMMARY}

The author presents the families, the genera, and as possible the species of Bryo. phytes so fal known, often found in the tropical rain-forest in a range of $150 \mathrm{Km}$ around Manaus. State of Amazonas, Brasil. Artificial keys for identification of classes, and in particular cases for identification of genera and species are presented. Each family is described in a succint way under the morphological viewpoint, the preferential habitat, and the general geographic distribution. The technical terms used in the descriptions are defined in most of botanical dictionaries or in the texts concerning to Bryothytes morphology, made easier with the the inclusion of 536 figuras in this monograph. 
1964 - The Mosses of Suriname. Flora of Suriname. Vol. 6. Leiden.

1963-1976 - Manual of the Leafy Hepaticae of Latin America - Parts I-IV. Mem. New York. Bot. Gard. 11(1-4): 1-535.

1975 - A Taxonomic Monograph of the Genus Acrolejeunea (Hepaticae). Bryophytorum Bibliotheca, bd. 4, J. Cramer, Lehre.

1869 - Musci austro-americani. Enumeratio muscorum omnium austro-americanorum auctori hucusque cognitorum. Jour. Linn. Soc. Lond., Bot. 12: 1-659.

1961 - The genus Calymperes in the Americas. The Bryologist 64: 89-140.

1955 - North American Lejeuneaceae I. Introduction; Keys to subfamilies and genera. Jour. Elisha Mitchell Sci. Soc. 71(1): 106-148.

1884 - Hepaticae amazonicae et andinae. Trans. Proc. Bot. Soc. Edinburgh 15: I-XI, 1-500, pls. 1-22.

(Aceito para publicaçäo em 9/06/79) 


\section{ESTAMPA I}

Fig. 1-5 - Sphagnum palustre. Fig. 1, planta $X 4$; fig. 2, filídio do caule primário $X 20$; fig. 3 , filídio do ramo $\times 20$. fig. 4, células da metade superior do filídio dum ramo $X 170$; fig. 5 , secção transversal do filídio dum ramo $X 300$. Fig. 6-8 - Fissidens kegelianus. Fig. 6, filídio X 20; fig. 7, ápice do filídio X 120; fig. 8, parte inferior do filídio $X 120$. Fig. 9-11 - Fissidens elegans. Fig. 9, filídio $X$ 120: fig. 10, margem inferior do filídio $X$ 170; fig. 11 células da parte superior da lâmina X 400 .

Fig. 12-14 - Fissidens prionodes - Fig. 12, planta $X$ 6; fig. 13, filídio $X$ 35; fig. 14, ápice do filídio $X 180$.

Fig. 15-17 - Fissidens intermedius. Fig. 15, filídio $X 35$; fig. 16, parte inferior do filídio $X 160$; fig. 17, células da parte superior da lâmina X 300 .

Fig. 18-20 - Campylopus trachyblepharon. Fig. 18, planta $X 3$; fig. 19, filidio X 7; fig. 20, secção transversal do filidio $\mathrm{X} 180$.

Fig. 21-24 - Campylopus surinamensis. Fig. 21, planta $X$ 4; fig. 22, filídio $X$ 17; fig. 23, ápice do filídio $X 130$; fig. 24 , margem mediana do filidio $X 150$.

Fig. 25-28 - Campylopus savannarum. Fig. 25, planta $X 4$; fig. 26, filídio $X 10$; fig. 27, regiảo alar $X 60$; fig. 28 , secção transversal do filidio $\mathrm{X} 180$.

Fig. 29-33 - Dicranella hilariana. Fig. 29, planta X 8; fig. 30, filídio X 30; fig. 31, ápice do filídio $X 300$; fig. 32, cápsula $X 8$; fig. 33 , dente do peristômio $X 40$.

Fig. 34-36 - Leucobryum crispum. Fig. 34 , planta $X 2$; fig. 35, filídio $X 7$ : fig. 36 , secçäo transversal do filidio perto da base $\times 130$.

Fig. 37-39 - Leucobryum martianum. Fig. 37, planta $X 2$; fig 38, filídio $\times 7$; fig. 39, secçăo transversal do filídio perto da base $\times 130$.

Fig. 40-43 - Octoblepharum cocuiense. Fig. 40, planta $X 3$; fig. 41, filídio $X$ 5; fig. 42-43, ápices de filidios $X 20$.

Fig. 44-48 - Octoblepharum pellucidum. Fig. 44 filídio $X 5$; fig. 45-47, ápices de filídios X 20; fig. 48, secção transversal do filídio perto do ápice $X 100$.

Fig. 49-50 - Octoblepharum ampullaceum. Fig. 49, ápice do filídio $X 40$; fig. 50 , secção transversal e mediana do filídio $X 80$.

Fig. 51-55 - Octoblepharum albidum. Fig. 51, planta, $X 7$; fig. 52, filídio $X$ 10; fig. 53, ápice do filídio $X 20$; fig. 54 , secção transversal do filídio perto do ápice $X 80$; fig. 55 , peristômio $X 100$. 

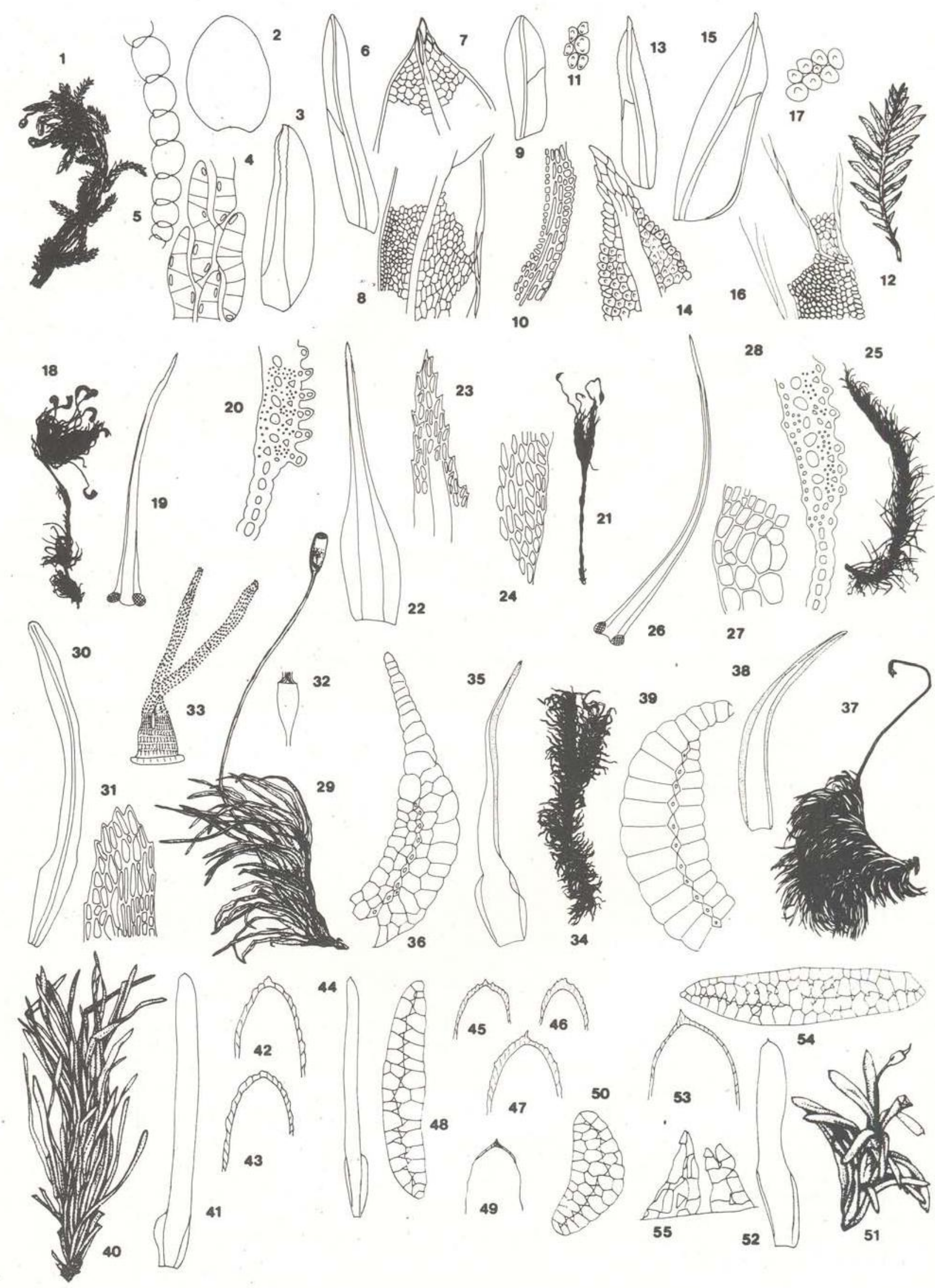


\section{ESTAMPA ॥}

Fig. 56-62 - Octoblepharum cylindricum. Fig. 56, planta $X 15$; fig. 57, filidio $X 5$; fig. 58 , ápice do filidio $X 40$; fig. 59-60, células do meio superior da lâmina $X 80$; fig. 61 , cápsula $X 12$; fig. 62, peristômio $X 35$.

Fig. 63-67 - Octoblepharum pulvinatum. Fig. 63, filidio $X$ 8: fig. 64-65, ápices de filídios; fig. 66 , células do meio superior da lâmina $\times 70$; fig 67 , peristômio $\times 70$.

Fig. 68-70 - Calymperes lonchophyllum. Fig. 68, planta $X 3$; fig. 69, filídio $X 5$; fig. 70, células superiores do filidio $\times 300$.

Fig. $71-74$ - Calymperes rubiginosum. Fig. $71-72$ filídios $X 13$; fig. 73 , ápice do filídio $X 130 ;$ fig. 74 , margem do filidio $\times 150$.

Fig. 75-77 - Calymperes mitrafugax. Fig. 75 filídio $X$ 13; fig. 76 , secçăo transversal da metade superior do filidio $X$ 170; fig. 77, margem superior do filídio X 170 .

Fig. 78-81 - Calymperes lanceolatum. Fig. 78-79, filídios $X 7$; fig. 80, ápice do filidio $X$ 110; fig. 81, células superiores do filidio (lado dorsal) $\times 300$.

Fig. 82-84 - Calymperes platyloma. Fig. 82, planta $X$ 4; tig. 83, filídio $X 7$; fig. 84, secção transversal da metade superior do filídio $X 170$.

Fig. 85-90 - Calymperes bartramii. Fig. 85, planta $\times 4$; fig. 86, tilidio $\times 7$; fig. 87-88, secçōes transversais da lâmina superior do filídio X 140; fig. 89, o mesmo X 220; fig. 90, teniolas marginais na regiăo do ombro do filídio $X 160$.

Fig. 91-95 - Calymperes richardii. Fig. 91, planta X 4; fig. 92-93, filídios $X 7$; fig. 94, secçăo transversal da lâmina superior; fig. 95, teniolas intramarginais na regiăo do ombro do filídio $\times 250$

Fig. 96-99 - Calymperes donnellii. Fig. 96, filidio X 7; fig. 97, secçăo transversal da lâmina superior do filídio $X 300$; fig. 98, secção transversal da região superior das cancelinas $\times 70$; fig. 99 , teniolas intramarginais na regiảo do ombro do filídio $\mathrm{X} 260$.

Fig. 100-104 - Calymperes erosum. Fig. 100, planta X 5; fig. 101-102, filídios X 7; fig. 103, secção transversal da regiâo superior das cancelinas $\times 70$; fig. 104, teniolas intramarginais na região do ombro do filídio $X 170$.

Fig. 105-109 - Syrrhopodon helicophyllus. Fig. 105, planta $X$ 2; fig. 106, filidio em estado seco $X$ 13; fig. 107, filídio em estado úmido X 7; fig. 108, ápice do filídio X 60; fig. 109, células superiores do filídio $X 220$.

Fig. 110-112 - Syrrhopodon ligulatus. Fig. 110-111, filídios X 17; fig. 112, células superiores do filídio $X 230$.

Fig. 113-115 - Syrrhopodon fimbriatus. Fig. 113-114, filidios X 26; fig. 115, margem do filidio X 180 .

Fig. 116-119 - Syrrhopodon xanthophyllus. Fig. 116-117, filidios $X 12$; fig. 118, secção transversal do filídio $X 43$; fig. 119, secção transversal da margem do filídio $X 230$.

Fig. 120-122 - Syrrhopodon brevisetus. Fig. 120, filidio X 13; fig. 121, ápice do filídio X 140; fig. 122, secção transversal da metade superior do filídio $\times 230$.

Fig. 123-125 - Syrrhopodon incompletus. Fig. 123, filídio X 7; fig. 124, margem superior do filídio X 110; fig. 125, células da região superior das cancelinas X 200 .

Fig. 126-128 - Syrrhopodon annotinus. Fig. 126, filídio $X$ 7; fig. 127, margem superior do filídio $X$ 160; fig. 128, células superiores do filídio $\times 300$. 


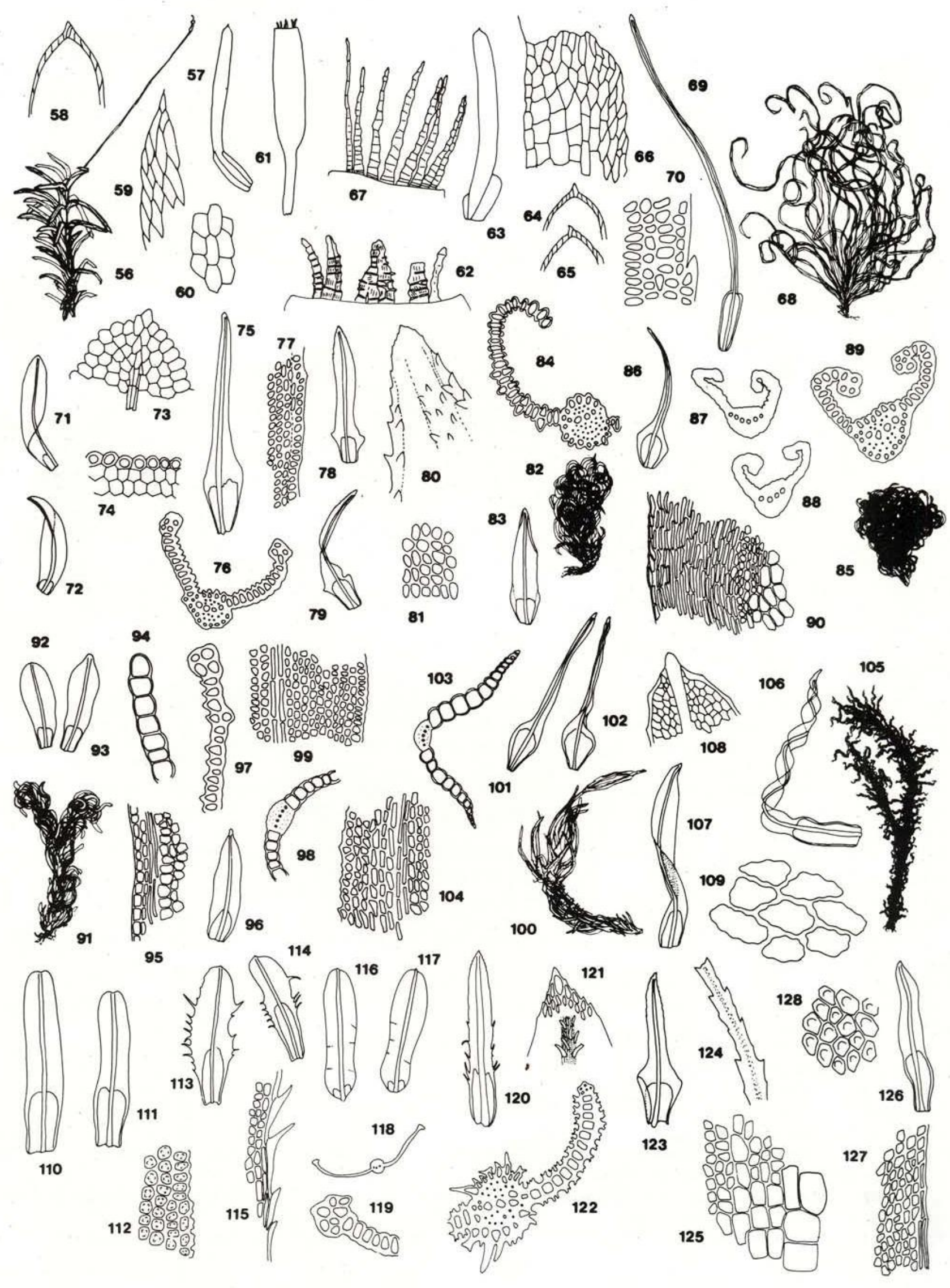




\section{ESTAMPA III}

Fig. 129-132 - Syrrhopodon sylvaticus. Fig. 129, planta X 3; fig. 130, filidio X 7; fig. 131, borda acima dos ombros do filídio X 50; fig. 132, células da lâmina superior (lado dorsal) X 300 .

Fig. 133-136 - Syrrhopodon leprieurii. Fig. 133-134, filídios X 7; fig. 135, borda acima dos ombros do filídio $X 50$; fig. 136. células da lâmina superior (lado dorsal) $\times 300$.

Fig. 137-138 - Syrrhopodon parasiticus. Fig. 137, filídio X 7; fig. 138, células da lâmina superior X 300 .

Fig. 139-141 - Syrrhopodon parasiticus var. disciformis. Fig. 139, filídio X 17; fig. 140, margem superior do filidio X 200; fig. 141, células da lâmina superior X 300 .

Fig. 142-146 - Syrrhopodon cryptocarpos. Fig. 142, planta X 4; fig. 143, cápsula $X 7$; fig. 144, filídio $X$ 12; fig. 145, margem superior do filídio X 200; fig. 146, células da lâmi na superior X 300 .

Fig. 147-150 - Syrrhopodon rigidus. Fig. 147, planta $X 3$; fig. 148, filidio propaguloso $X 7$; filidio normal $X 7$; fig. 150 , ápice do filidio normal $X 60$.

Fig. 151-154 - Syrrhopodon hornschuchii. Fig. 151, planta $X 3$; fig. 152, filidio $X 5$; fig. 153, margem inferior do filídio $X 170$; fig. 154, ápice do filídio $X 80$.

Fig. 155-156 - Syrrhopodon circinatus. Fig. 155 margem inferior do filídio $X$ 170; fig. 156, ápice do filídio $X 80$.

Fig. 157-161 - Barbula agraria. Fig. 157, planta X 5; fig. 158-159, filídios X 17; fig. 160, células superiores do filidio $X$ 130; fig. 161, células inferiores do filidio $X 130$.

Fig. 162-164 - Hyophila tortula. Fig. 162, planta X 8; fig. 163, filídio $X 15$; fig. 164, células superiores do filídio $X 300$. Fig. 165-170 - Groutiella mucronifolia. Fig. 165-166, filidios X 17; fig. 167, margem inferior do filídio X 300; fig. 168, ảpice do filídio X 250; fig. 169 , cápsula X 5; fig. 170 , caliptra $X 5$.

Fig. 171-177 - Macromitrium pellucidum. Fig. 171-172, filídio $X$ 13; fig. 173, células apicais do filídio $X 250$; fig. 174 . células medianas do filídio $X 250$; fig. 175 , células basais do filídio $X 250$; fig. 176 , cápsula $X 5$; fig. 177 , caliptra $X 5$. Fig. 178-182 - Macromitrium pentastichum. Fig. 178, filídio X 17; fig. 179, células apicais do filídio X 130 ; fig. 180. células basais do filídio $X 130$; fig. 181, cápsula $X 5$; fig. 182, caliptra $X 5$.

Fig. 183-187 - Bryum coronatum. Fig. 183, planta X 3; fig. 184-185, filidios X 17; fig. 186, células superiores do folidio X 250; fig. 187, peristômio X 80 .

Fig. 188-191 - Bryum cruegerí. Fig. 188, planta X 3; fig. 189-190, filídios X 17; fig. 191, células superiores do filidio $\times 250$. 

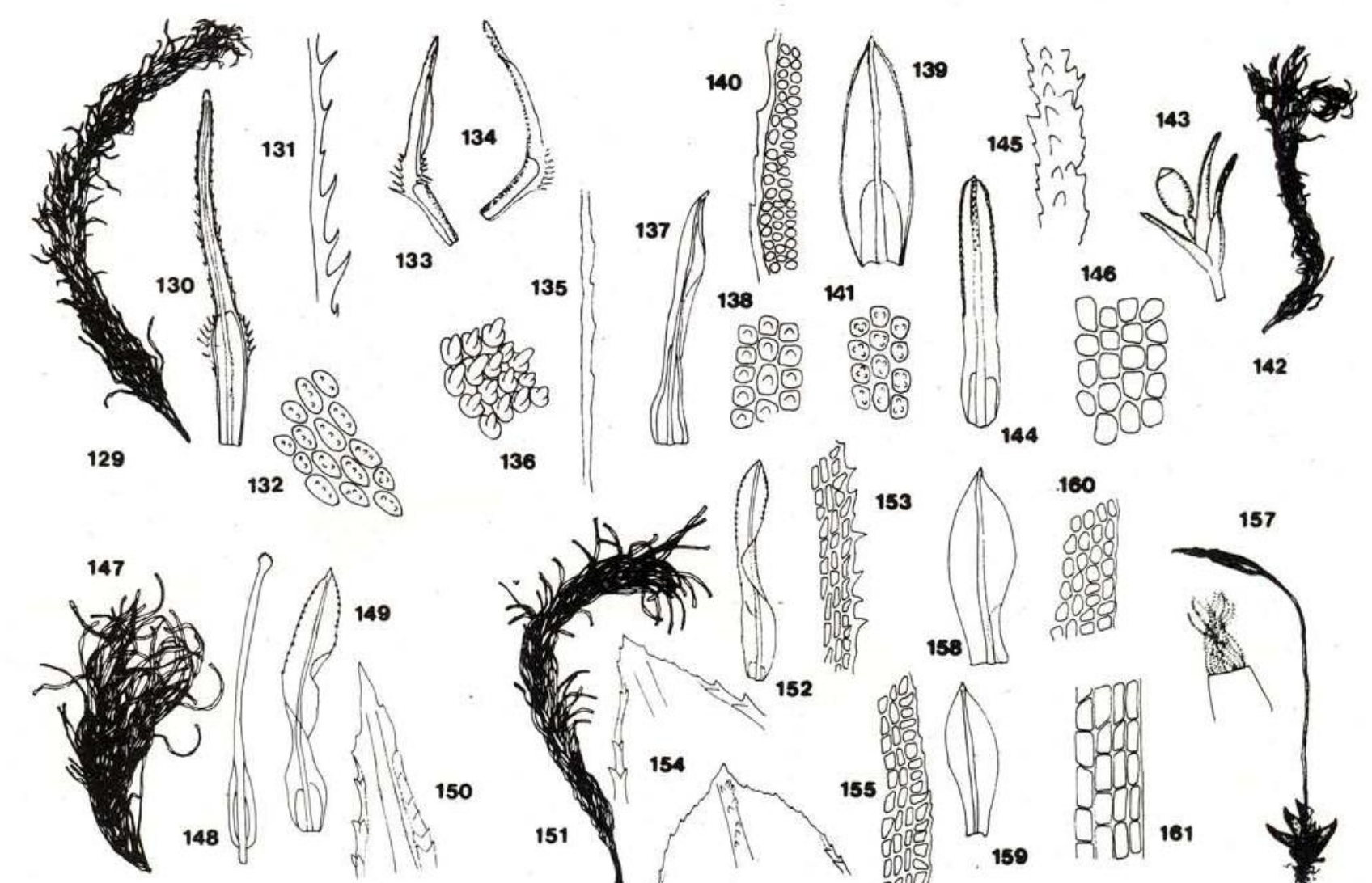

136
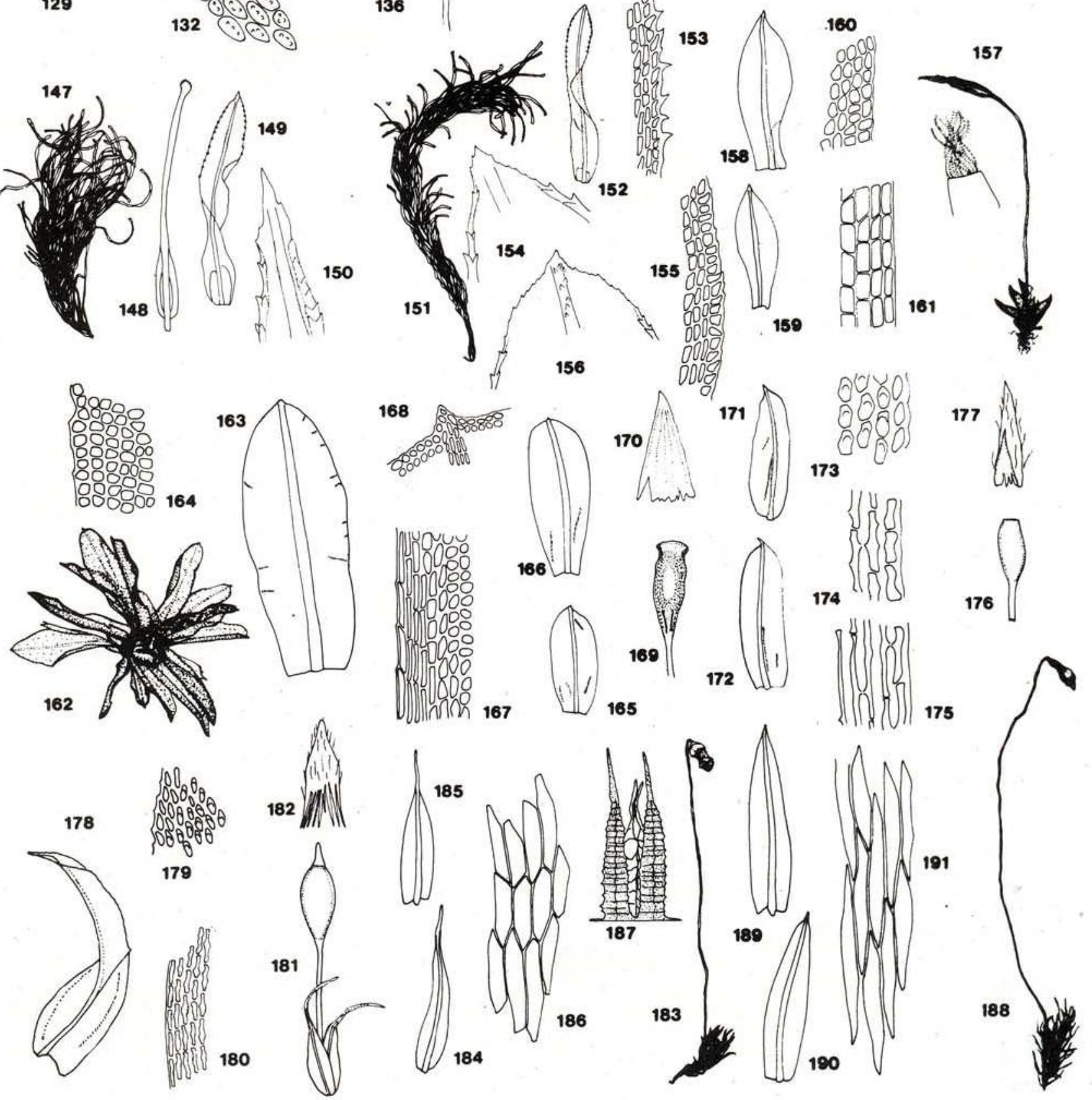


\section{ESTAMPA IV}

Fig. 192-194 - Mniomalia viridis. Fig. 192, planta X 5; fig. 193, filidio X 25; fig. 194, células superiores do filídio X 300 .

Fig. 195-197 - Phyllodrepanium falcifolium. Fig. 195, planta X 4; fig. 196, filídio X 10; fig. 197, células medianas do filidio $\times 300$.

Fig. 198-200 - Philonotis uncinata. Fig. 198, planta X 3; fig. 199, filídio X 35; fig. 200, células superiores do filídio $\mathrm{X} 260$.

Fig. 201-204 - Leucodontopsis geniculata. Fig. 201, planta X 1,5; fig. 202, filídio X 26; fig. 203, células superiores do filidio X 350; fig. 204, células da regiảo alar X 210 .

Fig. 205-209 - Pireella pohlii. Fig. 205, planta X 1,5; fig. 206-207, filidios X 26; fig. 208, células superiores do filidio $X$ 350; fig. 209, células da região alar X 260.

Fig. 210-213 - Meteoriopsis patula. Fig. 210, planta X 1,5; fig. 211-212, filídios X 13; fig. 213, células medianas do filídio $\times 300$.

Fig. 214-217 - Neckeropsis disticha. Fig. 214, planta X 1,5; fig. 215-216, filídios $X$ 13; fig. 217, cápsula $X 17$.

Fig. 218-220 - Neckeropsis undulata. Fig. 218, planta $X$ 1,5; fig. 219-220, filídios $X 13$.

Fig. 221-224 - Pilotrichum evanescens. Fig. 221, planta $X$ 1,5; fig. 222, filidio $X$ 18; fig. 223, ápice do filídio $X 80$; fig. 224 , células superiores do filídio X 300 .

Fig. 225-229 - Callicostella sp. Fig. 225, planta X 3; fig. 226-227, filídios X 35; fig. 228, ápice do filídio X 80; fig. 229, células superiores do filídio $\mathrm{X} 180$.

Fig. 230-233 - Crossomitrium patrisiae. Fig. 230, planta $X$ 8; fig. 231, filídio lateral $X$ 13; fig. 232, filídio dorsal $X$ 13; fig. 233, propágulo filamentoso $\times 40$.

Fig. 234-236 - Hookeriopsis parkeriana. Fig. 234, planta $X 1,5$; fig. 235, filídio $X 13$; fig. 236, células superiores do filídio $\times 260$. 


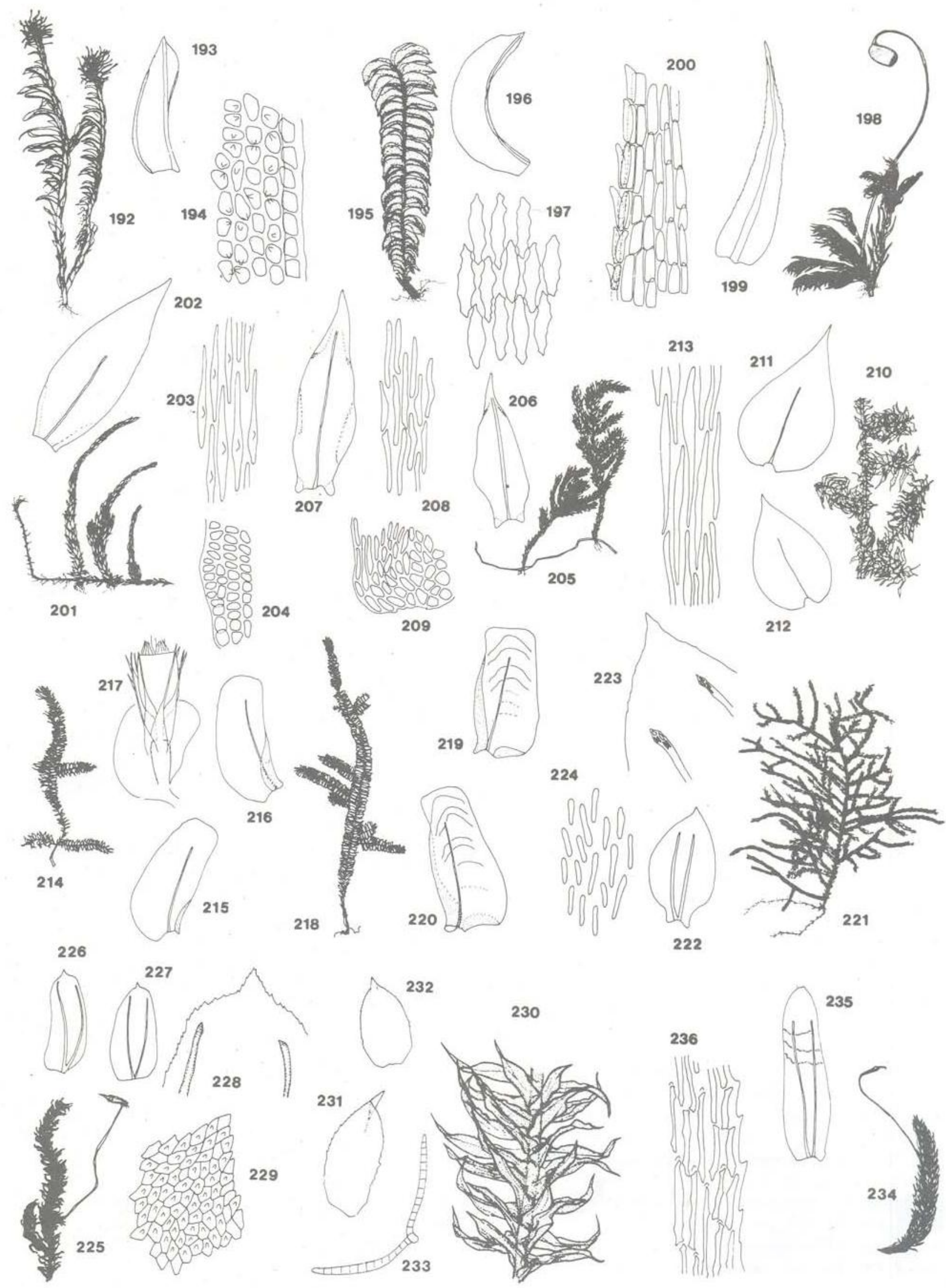




\section{ESTAMPA $\mathbf{V}$}

Fig. 237-240 - Leucomium lignicola. Fig. 237, planta $X$ 5: fig. 238, filídio X 20; fig. 239, células superiores do filidio X 270; fig. 240, caliptra X 12 .

Fig. 241-245 - Thuidium involvens. Fig. 241, planta $X$ 10; fig. 242, filídio do caule primário X 27; fig. 243, filidio do ramo X 27; fig. 244, ápice do filídio do ramo $X 170$; fig. 245 , filídio periquecial $X 18$.

Fig. 246-254 - Thiudium schistocalyx. Fig. 246, planta $X 3$, fig. 247 , planta $X 10$; fig. 248 , filidio do caule primário $X 30$; fig. 148-250, filídios do ramo $X 50$; fig. 251 , ápice do filídio do ramo $X 200$; fig. 252 , filídio periquecial $X 25$; fig. 253 , parafilia X 230; fig. 254, secção da seta X 30 .

Fig. 255-260 - Isopterygium tenerum. Fig. 255, planta $X$ 2,5; fig. 256-258, filídios $X$ 17; fig. 259, células medianas do filidio X 200; fig. 260, células da base do filídio X 180 .

Fig. 261-264 - Isopterygium auranticum. Fig. 261, planta $X 2$; fig. 262, filídio $X 2$; fig. 263, células medianas do filídio X 200; fig. 264, células da base do filidio $X 110$.

Fig. 265-268 - Pilosium chlorophyllum. Fig. 265, planta $X 2$; fig. 266-267, filidios $X 2$; fig. 268, células medianas do filidio $X 130$.

Fig. 269-271 - Stereophyllum leucostegeum. Fig. 269, planta $X$ 3; fig. 270, filidio $X$ 17; fig. 271, região alar do filidio $\times 50$.

Fig. 272-275 - Acroporium guianense. Fig. 275, planta X 2; fig. 273, filídio $X$ 15; fig. 274, região alar do filidio $X$ 50; fig. 275, células superiores do filídio $\times 500$.

Fig. 276-280 - Meiothecium revoubile. Fig. 276, planta X 2; fig. 277-278, filídlo X 15; fig. 279, região alar do filídio X 150; fig. 280 , peristômio $\times 420$.

Fig. 281-284 - Pterogonidium pulchelum. Fig. 281, planta $X$ 5; fig. 282, filídio $X$ 40; fig. 283, região alar do filídio $X$ 130; fig. 284, cápsula X 20.

Fig. 285-289 - Sematophyllum subsimplex. Fig. 285, planta X 2; fig. 286-287, filídios X 13; fig. 288, regiāo alar do filídio $X$ 170; fig. 289, células medianas do filídio $X 300$; fig. 290, peristômio $X$.

Fig. 291-295 - Sematophyllum caespitosum. Fig. 291, planta X 3; fig. 292-293, filídios X 17; fig. 294, regiāo alar do filídio $X 150$; fig. 295, células medianas do filídio $X 160$. 

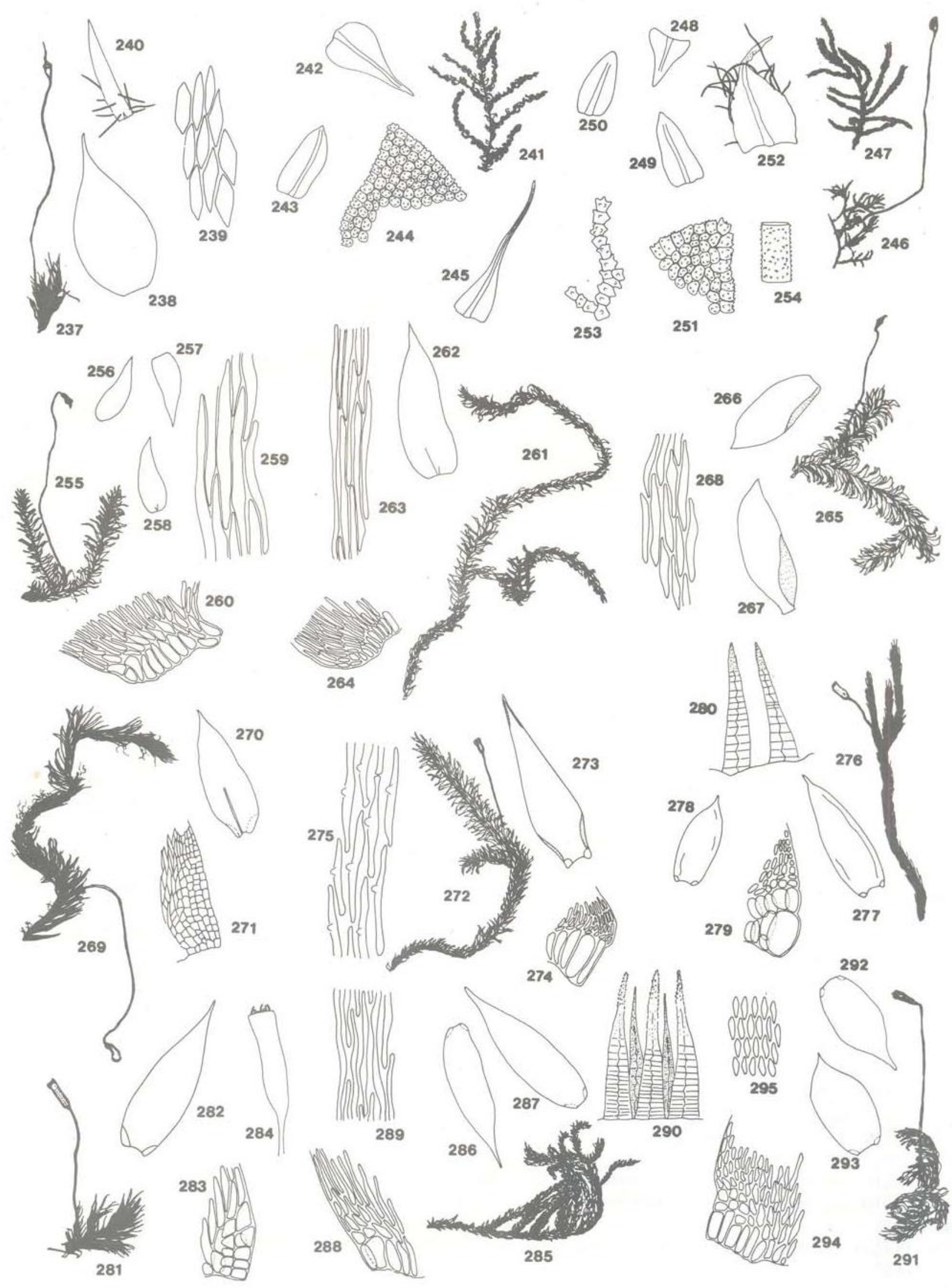


\section{ESTAMPA VI}

Fig. 296-301 - Taxithelium planum. Fig. 296, planta X 3; fig. 297-299, filídios X 17; fig. 300, região alar do filidio $X$ 170; fig, 301, células superiores do filídio $X 300$.

Fig. 302-306 - Trichosteleum guianae. Fig. 302, planta $X 2$; fig. 303-304, filidios $X 20$; fig. 305 , região alar do filídio X 120; fig. 306, células superiores do filídio $X 260$.

Fig. 307-311 - Trichosteleum fluviale. Fig. 307, planta X 4; fig. 308-309, filidios X 20; fig. 310, região alar do filidio $X 150$; fig. 311 , células superiores do filídio $X 580$.

Fig. 312-315 - Rhacopilopsis trinitensis. Fig. 312, planta $X 17$; fig. 313, filidio dorsal $X$ 20; fig. 314, filidio ventral $X$ 20 ; fig. 315, margem superior dum filídio dorsal $X 220$.

Fig. 316-319 - Vesicularia amphibola. Fig. 316, planta $X$ 3; fig. 317-318, filídios $X$ 26; fig. 319, margem superior do filidio $\times 100$.

Fig. 320-323 - Bazzania phyllobola. Fig. 320, planta $X 20$; fig. 321, filídio $X$ 30; fig. 322-323, anfigástrios $X 40$.

Fig. 324 - Bazzania gracilis. Fig. 324, planta X 15.

Fig. 325-330 - Bazzania teretiuscula. Fig. 325, planta X 5; fig. 326-327, filídios X 10; fig. 328-330, anfigástrios $X 20$. Fig. 331-335 - Bazzania pallide-virens. Fig. 331, planta $X 5$; fig. 332, filídio $X 10$; fig. 333-334, anfigástrios $X 20$; fig. 335 , células superiores do filídio $X 210$.

Fig. 336-338 - Micropterygium leiophyllum. Fig. 336, planta X 4; fig. 337, aumento duma porção da planta $X 30$; fig 338, ápice do filídio $X 170$.

Fig. 339-340 - Micropterygium pterygophyllum. Fig. 339, planta $X 30$; fig. 340, filídio $X 30$.

Fig. 341-343 - Micropterygium trachyphyllum. Fig. 341, planta $X$ 26; fig. 342, filídio $X 40$; fig. 343 , células do filidio $\times 400$.

Fig. 344-346 - Micropterygium parvistipulum. Fig. 344, planta $X$ 20; fig. 345, filídio X 40; fig. 346, células do filidio $\times 400$. 

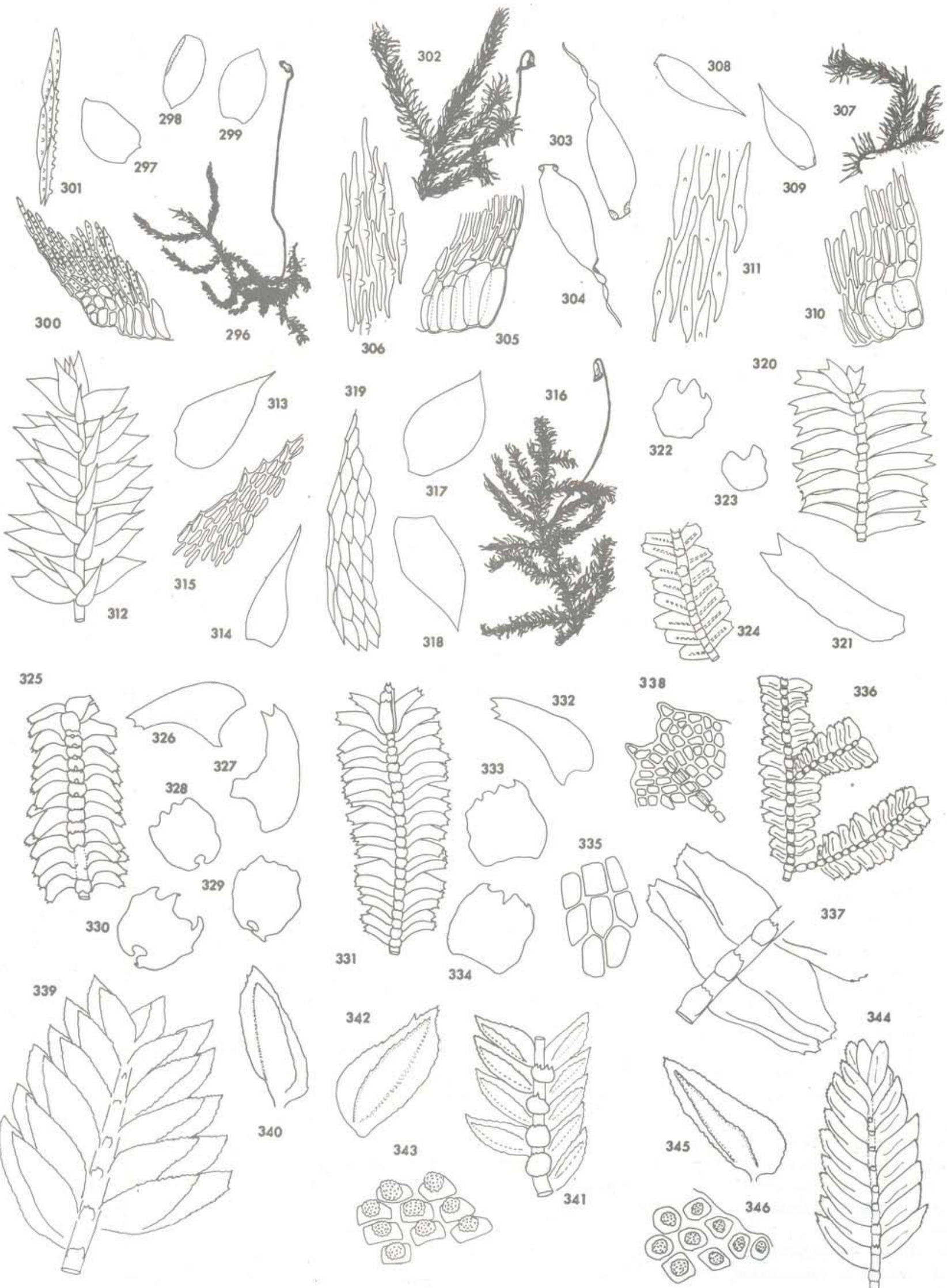

337 


\section{ESTAMPA VII}

Fig. 347-348 - Calypogeia amazonica. Fig. 347, planta $X 10$; fig. 348 , ápice do filídio $\times 80$.

Fig. 349-350 - Calypogeia tenax. Fig. 349, planta $X$ 10: fig. 350, ápice do filídio $X 80$.

Fig. 351-352 - Calypogeia parallelogramma. Fig. 351, planta $X 15$; fig. 352, ápice do filídio $X 80$

Fig. 353-354 - Calypogeia rhombifolia. Fig. 353, planta $X 13$; fig. 354 , ápice do filídio $X 80$.

Fig. 355-356 - Calypogeia lechleri. Fig. 355, planta $X$ 20; fig. 356, ápice do filídio $X 80$.

Fig. 357-358 - Lophocolea liebmanniana. Fig. 357, planta $X$ 40; fig. 358, ápice do filídio $X 100$.

Fig. 359-361 - Lophocolea perissodonta. Fig. 359, planta $X 7$; fig. 360, anfigástrio $X$ 20; fig. 361, perianto $X 4$.

Fig. 362-363 - Lophocolea martiana. Fig. 362, planta $X 2$; fig. 363 , anfigástrio $X 40$

Fig. 364-367 - Plagiochila rutilans. Fig. 364, planta em estado seco X 7; fig 365, planta em estado úmido X 6 ; fig 366, filídio $X 10$; fig. 367, células do filídio $X 200$.

Fig. 368-370 - Plagiochila subplana. Fig. 368, planta X 5; fig. 369, filídio X.7; fig. 370, células do filídio $X 200$.

Fig. 371-372 - Plagiochila hylaecoetis. Fig. 371, planta $X 10$; fig. 372, filídio $X 10$.

Fig. 373-375 - Plagiochila thysanotis. Fig. 373, planta $X 10$ : fig. $374-375$, filídio $X 13$.

Fig. 376-378 - Odontoschisma brasiliense. Fig. 376, planta $X 10$; fig. 377, filídio $X 20$; fig. 378, células do filídio $X$ 190.

Fig. 379 - Odontoschisma falcifolium. Fig. 379, filidio $\times 20$.

Fig. 380-382 - Anomoclada muscosa. Fig. 380, planta $X 13$; fig. 381, filídio $X 20$; fig. 382, células do filídio $X 200$. 

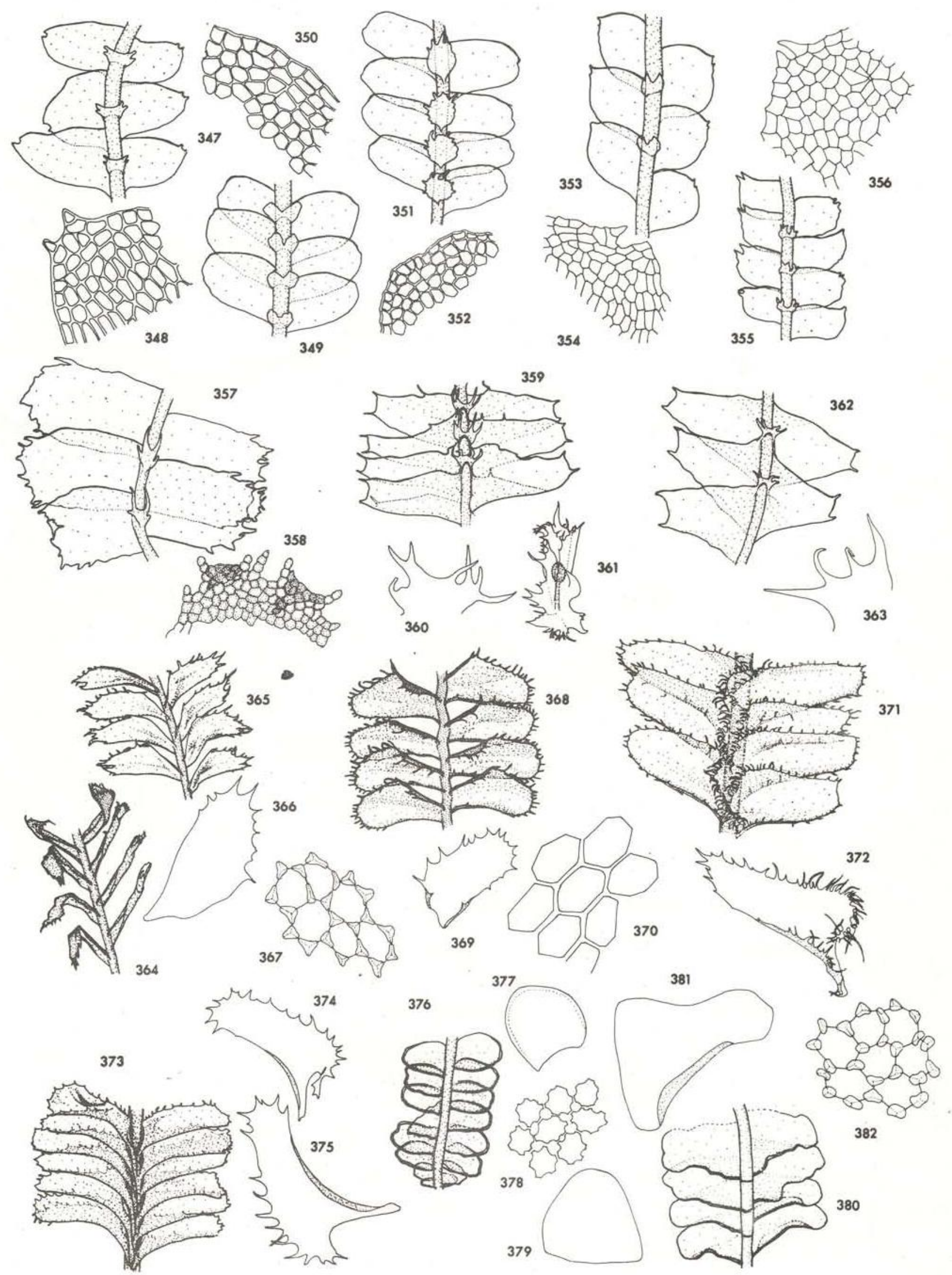


\section{ESTAMPA VIII}

Fig. 383-384 - Arachniopsis coatilis. Fig. 383, planta X 20; fig. 384, aumento duma porção da planta X 300 .

Fig. 385 - Arachniopsis pecten. Fig. 385, planta X 15 .

Fig. 386 - Telaranea sejuncta. Fig. 386, aumento duma porção da planta $X 110$.

Fig. 387-389 - Microlepidozia verrucosa. Fig. 387, planta X 5; fig. 388, aumento duma porção da planta X 130; fig.

389 , ápice dum segmento dum filídio $\mathrm{X} 400$.

Fig. 390-391 - Mytilopsis albifrons. Fig. 390, planta $X 35$; fig. 391, ápice do filídio $X 220$.

Fig. 392-393 - Regredicaulis serrus. Fig. 392, planta X 23; fig. 393, ápice do lobo X 70 .

Fig. 394-395 - Zoopsis integrifolia. Fig. 394, planta X 40; fig. 395, ápice do lobo X 90 .

Fig. 396-398 - Radula flaccida. Fig. 396, planta (lado dorsal) X 10; fig. 397, vista ventral da planta X 30; fig. 398, perianto $\times 20$.

Fig. 399.402 - Frullania nodulosa. Fig. 399, planta X 2; fig. 400, vista ventral da planta X 10; fig. 401, vista ventral da planta sem anfigástrios $X 20$; fig. 402, anfigástrio $X 15$.

Fig. 403-406 - Frullania gibbosa. Fig. 403, planta $X$ 2; fig. 404, vista ventral da planta $X$ 13; fig. 405, lóbulo $X$ 45; fig. 406, anfigástrio $\times 20$.

Fig. 407-410 - Frullania montagnei. Fig. 407, planta $X 2$; fig. 408, vista ventral da planta $X 13$; fig. 409 , lóbulo $X$ 80; fig. 410, anfigástrio $X 20$.

Fig. 411-414 - Frullania neesii. Fig. 411, planta $X 5$; fig. 412, vista ventral da planta $X 20$; fig. 413, 16 bulo $X 100$; fig. 414, anfigástrio $\times 75$.

Fig. 415-420 - Caudalejeunea lehmanniana. Fig. 415, planta X 8; fig. 416-417, filídios X 20; fig. 418, anfigástrio X 20; fig. 419, células do filídio $\times 300$; fig. 420 , perianto $\times 20$. 

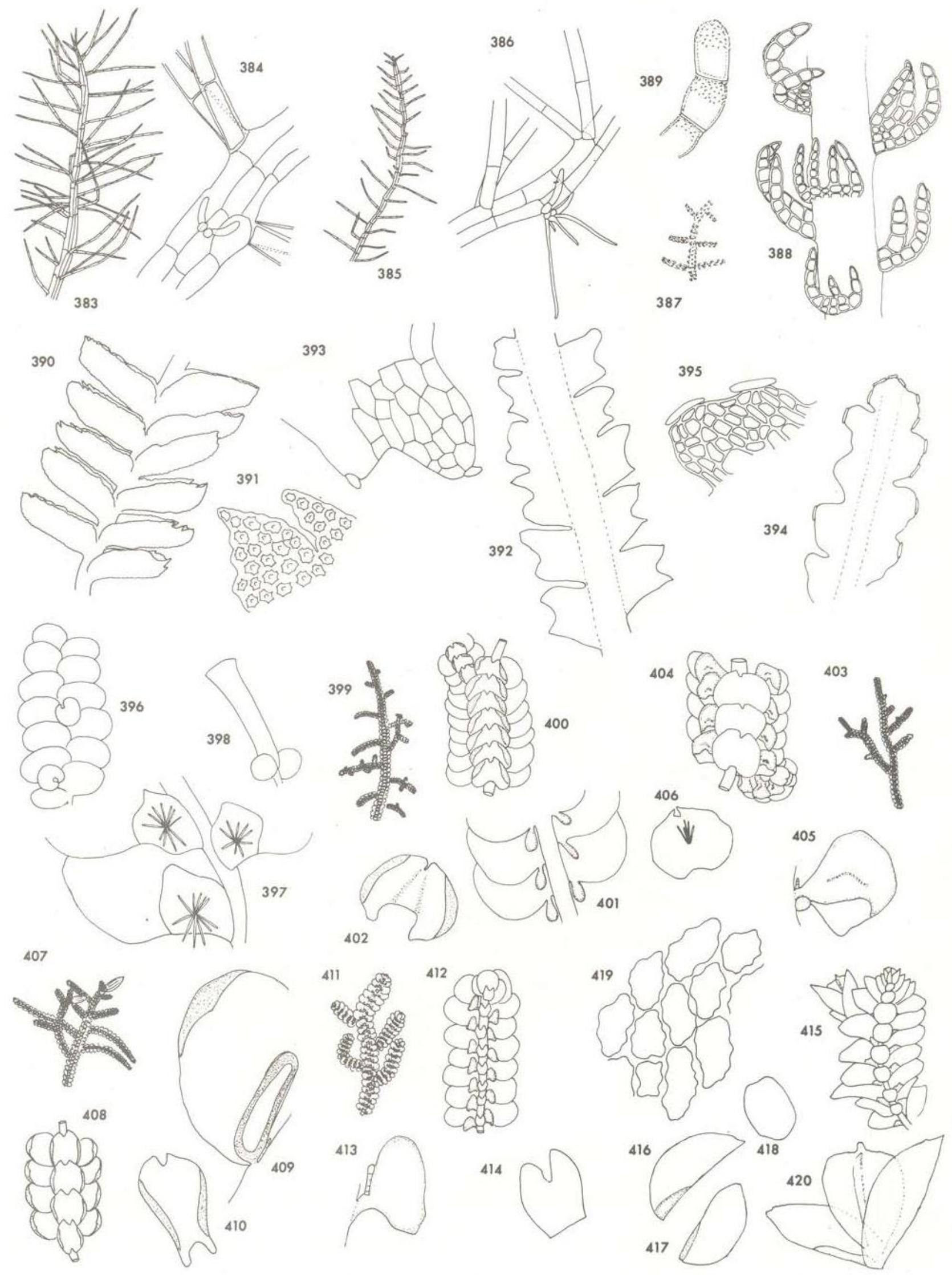


\section{ESTAMPA IX}

Fig. 421-424 - Mastigolejeunea auriculata. Fig. 421, planta $X$ 8; fig. 422, filídio $X$ 17; fig. 423, bráctea feminina $X 20$; fig. 424, perianto $\times 20$.

Fig. 425-427 - Thysananthus amazonicus. Fig. 425, planta $X 8$; fig. 426, bractéola feminina $X 20$; fig. 427, perianto $X$ 20.

Fig. 428-430 - Acrolejeunea emergens. Fig. 428, planta $X 8$; fig. 429, filidio $X 20$; fig. 430, perianto $X 20$.

Fig. 431 - Acrolejeunea torulosa. Fig. 431, folha $X 20$.

Fig. 432-434 - Odontolejeunea lunulata. Fig. 432, planta X 12; fig. 433, lóbulo do filídio $X 45$; fig. 434, anfigástrio X 45 .

Fig. 435-437 - Stictolejeunea squamata. Fig. 435, planta X 8; fig. 436, lóbulo do filídio X 30; fig. 437, células do filídio mostrando dois ocelos $X 300$.

Fig. 438-441 - Hygrolejeunea reflexistipula. Fig. 438, planta $X 8$; fig. 439, vista ventral do caule $X 70$; fig. 440 , filidio $X 20$; fig. 441, anfigástrio $X 20$.

Fig. 442-446 - Archilejeunea recurvans. Fig. 442, planta $X$; fig. 443, células do filídio $X 260$; fig. 444-445, brácteas femininas $X 8$; fig. 446 , perianto $\times 10$.

Fig. 447-449 - Verdoornianthus griffinii. Fig. 447, planta $X 8$; fig. 448, brácteas femininas $X 15$; fig. 449, perianto X 15.

Fig. 450-452 - Symbiezidium sp. Fig. 450, planta $X$ 8; fig. 451, células medianas do filídio $X 250$; fig. 452, perianto $X 8$.

Fig. 453-456 - Lopholejeunea subfusca. Fig. 453, planta $X 17$; fig. 454, uma porção da planta sem anfigástrios $X$ 17; fig. 455, células medianas do filídio $\times 245$; fig. 456 , perianto $X 30$.

Fig. 457-459 - Ceratolejeunea cornuta. Fig. 457, planta $X 13$; fig. 458, uma porção da planta sem anfigástrios $X 70$; fig. 459, perianto $X 20$.

Fig. 460-463 - Cheilolejeunea trifaria. Fig. 460, planta $X$ 8; fig. 461, anfigástrio X 20; fig. 462, lóbulo X 70 ; fig. 463 células medianas do filídio $X 200$. 

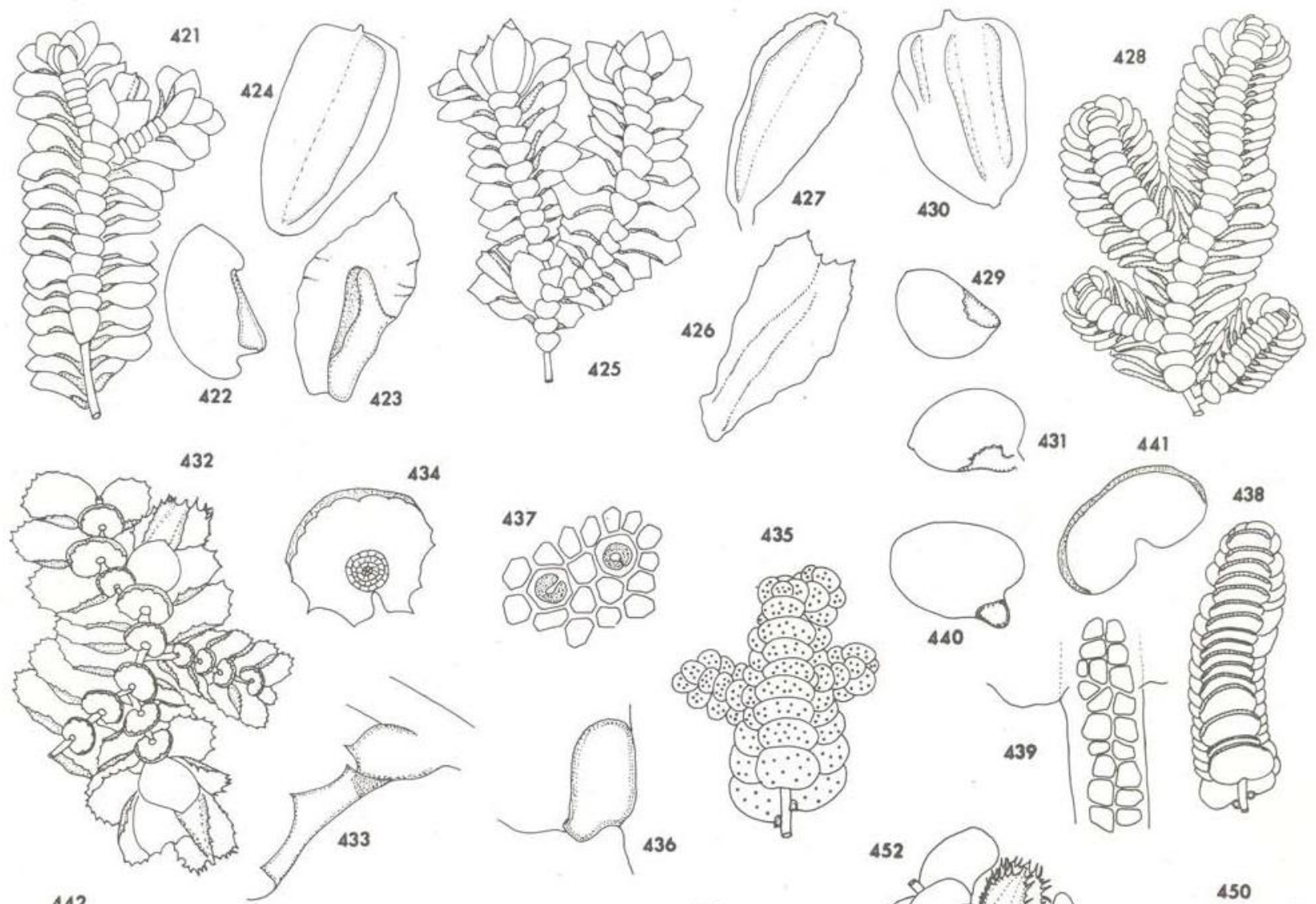

446)
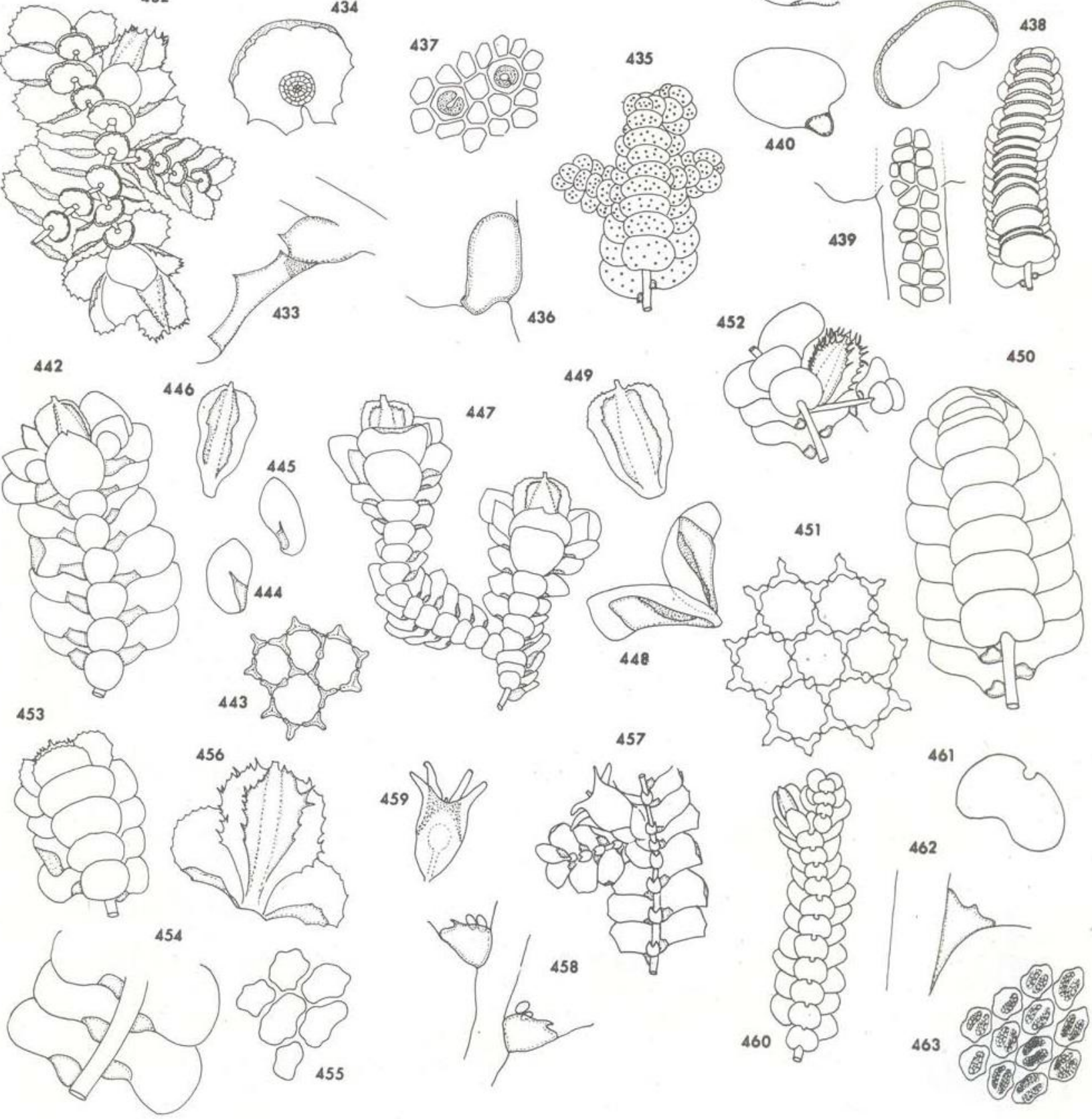


\section{ESTAMPA $X$}

Fig. 464-466 - Crossotolejeunea boryana. Fig. 464, planta $X$ 20; fig. 465, ápice do filídio $X$ 150; fig. 466, anfigástrio $\mathrm{X} 80$.

Fig. 467-469 - Drepanolejeunea palmifolia. Fig. 467, planta $X 35$; fig. 468, filídio $X$ 40; fig. 469, anfigástrio $X 120$.

Fig. 470-472 - Drepanolejeunea cf. bidens. Fig. 470, planta $X 86$; fig. 471, filidio X 100; fig. 472, anfigástrio $X 100$.

Fig. 473-474 - Harpalejeunea tenuicuspis. Fig. 473, planta $\times 70$; fig. 474, anfigástrio $X 160$.

Fig. 475-480 - Kingiolejeunea ornata. Fig. 475, planta $X$ 10; fig. 476, filidio $X$ 18; fig. 477, ápice do filidio $X 120$; fig. 478, anfigástrio X 18; fig. 479 , bráctea e bractéola femininas $X 18$; fig. 480 , perianto $\times 18$.

Fig. 481-483 - Lejeunea cf. flava. Fig. 481, planta X 20; fig. 482, vista ventral da planta sem anfigástrios $X 55$; fig. 483, células medianas do filídio $X 220$.

Fig. 484-485 - Leptolejeunea elliptica. Fig. 484, planta X 40; fig. 485, anfigástrio X 180 .

Fig. 486-488 - Microlejeunea cf. ulicina. Fig. 486, planta X 80; fig. 487, filidio X 140; fig. 488, anfigástrio X 140 .

Fig. 489-491 - Pycnolejeunea callosa. Fig. 489, planta X 18; fig. 490, vista ventral da planta sem anfigástrios $X 30$; fig. 491, perianto $\times 20$,

Fig. 492-493 - Potamolejeunea polystachya. Fig. 492, planta X 18; fig. 493, células medianas do filidio mostrando os ćleo-corpos X 300 .

Fig. 494-497 - Prionolejeunea sp. Fig. 494, planta X 18; fig. 495, vista ventral da planta sem anfigástrios X 80 ; fig. 496, ápice do filídio X 180; fig. 497, anfigástrio X 130 .

Fig. 498-500 - Rectolejeunea cf. maxonii. Fig. 498, planta $X 20$; fig. 499, vista ventral do filídio $X 70$; fig. 500, ápice do filidio $X 270$.

Fig. 501-503 - Taxilejeunea sp. Fig. 501, planta $X$ 20; fig. 502, anfigástrio $X$ 120; fig. 503, células medianas do filidio $\times 300$. 

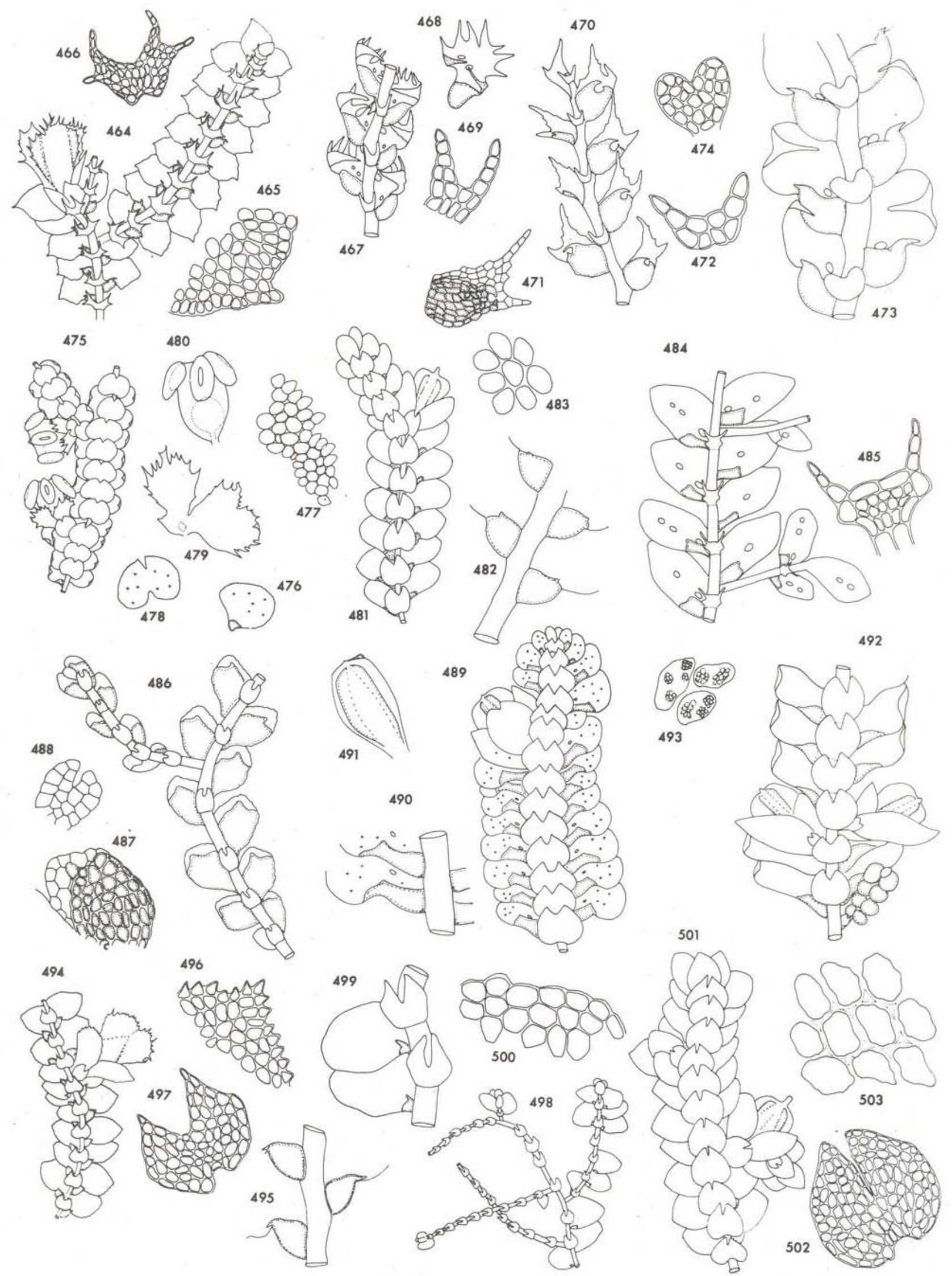
ESTAMPA XI

Fig. 504-506 - Colura cf. sagittistipula. Fig. 504, planta $X 13$; fig. 505, filídio $X 40$; fig. 506, anfigástrio $X 63$.

Fig. 507-511 - Diplasiolejeunea rudolphiana. Fig. 507, plan ta $X 15$; fig. 508, filídio $X 23$; fig. 509, anfigástrio $X 40$; fig. 510, perianto $X 15$; fig. 511, secção transversal do perianto $X 15$.

Fig. 512-513 - Aphanolejeunea sicaefolia. Fig. 512, planta $V 80$; fig. 513, filidio $X 200$

Fig. 514-515 - Cololejeunea sp. Fig. 514, planta $X 40$; fig. 515 , vista ventral da planta $X 80$.

Fig. 516-518 - Leptocolea cf. planifolia. Fig. 516, planta $X 18$; fig. 517, margem do filídio $X 200$; fig. 518, perianto $\mathrm{X} 30$.

Fig. 519-521 - Pallavicinia lyellii. Fig. 519, planta masculina $X 1,5$; fig. 520, planta feminina $X 1,5$; fig. 521, invólucro $\times 10$.

Fig. 522-524 - Symphyogyna brogniartii. Fig. 522, planta feminina X 2; fig. 523, margem do lobo $X$ 160; fig. 524, invólucro $\times 8$.

Fig. 525-526 - Aneura sp. Fig. 525, planta X 10; fig. 526 células superficiais do lado dorsal da planta $X 90$.

Fig. 527-528 - Riccardia sp. Fig. 527, planta X 5; fig. 528, planta com esporófito X 5 .

Fig. 529-531 - Ricciocarpos natans. Fig. 529, planta X 2; fig. 530, escama ventral X 4; fig. 531, margem serreada da escama ventral X 160 .

Fig. 532-533 - Anthoceros sp. Fig. 532, planta com esporćfitos X 2; fig. 533, células superficiais do lado dorsal da planta mostrando os cloroplastos maciços X 160 .

Fig. 534-536 - Pictolejeunea sprucei. Fig. 534, planta $X 18$; fig. 535, margem do filídio $X 170$; fig. 536, perianto $\mathrm{X} 18$. 

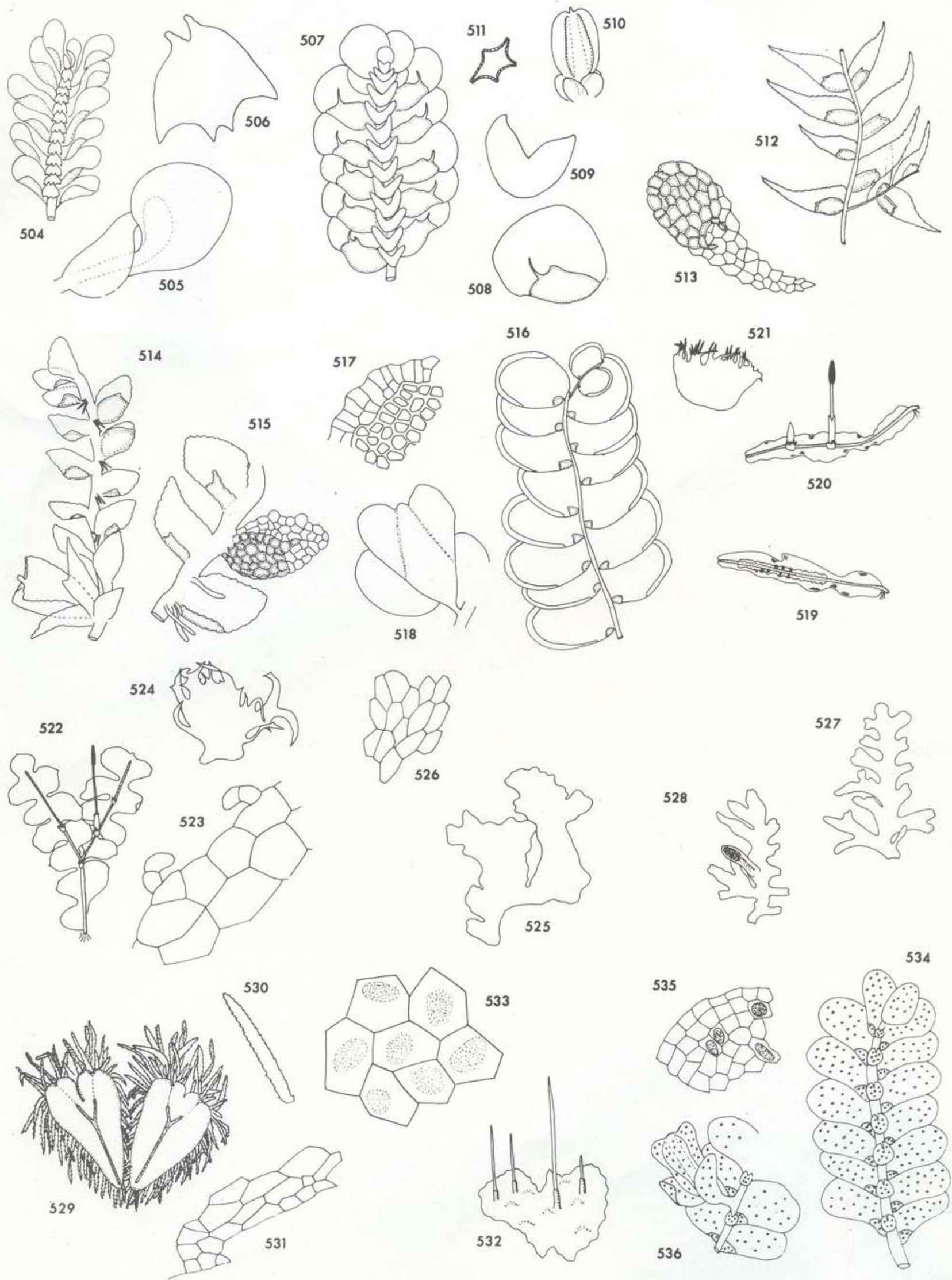